\title{
26. PETROLOGY AND GEOCHEMISTRY OF PLIOCENE-PLEISTOCENE VOLCANIC ROCKS FROM THE IZU ARC, LEG $126^{1}$
}

\author{
James B. Gill, ${ }^{2}$ Conrad Seales, ${ }^{2}$ Patricia Thompson, ${ }^{2}$ Alfred G. Hochstaedter, ${ }^{2}$ and Charles Dunlap ${ }^{2}$
}

\begin{abstract}
The igneous geochemistry of lavas and breccias from the basement of Sites 790 and 791 , and pumice clasts from the Pliocene-Pleistocene sedimentary section of Sites 788, 790, 791, and 793 were studied. Arc volcanism became silicic about $1.5 \mathrm{~m} . \mathrm{y}$. before the inception of rifting in the Sumisu Rift at $2 \mathrm{Ma}$, but eruption of these silicic magmas reflects changes in stress regime, especially during the last $130,000 \mathrm{yr}$, rather than crustal anatexis. Arc magmas have had a larger proportion of slab-derived components since the inception of rifting than before, but are otherwise similar. Rift basalts and rhyolites are derived from a different source than are arc andesites to rhyolites. The rift source has less slab-derived material and is an E-MORB-like source, in contrast to an N-MORB-type source overprinted with more slab-derived material beneath the arc. Rift magma types, in the form of rare pumice and lithic clasts, preceded the rift, and the earliest magmas that erupted in the rift already differed from those of the arc. The earliest large rift eruption produced an exotic explosion breccia ("mousse") despite eruption at $>1800$ mbsl. Although this rock type is attributed primarily to high magmatic water content, the clasts are more MORB-like in trace element and isotopic composition than are modern Mariana Trough basalts. After rifting began, arc volcanism continued to be predominantly silicic, with individual pumice deposits containing clasts that vary in composition by about $5 \mathrm{wt} \% \mathrm{SiO}_{2}$, or about as much as in historical eruptions of submarine Izu Arc volcanoes. The overall variations in magma composition with time during the inception of arc rifting are broadly similar in the Sumisu Rift and Lau Basin, though newly tapped OIB-type mantle seems to be present earlier during basin formation in the Sumisu than Lau case.
\end{abstract}

\section{INTRODUCTION}

At their extremes, magmas associated with the two end-member tectonic categories - divergent and convergent plate boundaries-are clearly different: mid-ocean-ridge (MORB) vs. island-arc basalts (IAB). Because these also are volumetrically the most important magma types on Earth, and together are responsible for the differentiation of the planet, they have attracted abundant attention. However, distinctions between the two tectonic categories as well as between the two magma types blur in backarc basins. Because backarc basin basalt (BABB) may become less IAB-like and more MORB-like as the distance between convergent and divergent boundaries grows during widening of backarc basins (Saunders and Tarney, 1984), the greatest blurriness is expected during the inception of backarc rifting. Consequently, this study focuses on the composition of volcanic rocks erupted (1) in the central Izu Arc before and after the most recent inception of backarc rifting there, and (2) within one of the backarc rifts, the Sumisu Rift (Fig. 1). Throughout this chapter, "rifting" refers to the extensional phase before formation of new oceanic crust within a backarc basin, whereas "spreading" refers to the formation of this new crust. Rifting is inferred to have begun in the Sumisu Rift at about $2 \mathrm{Ma}$, but spreading has not yet occurred (B. Taylor, this volume).

In addition to bearing on the geodynamic history of arc rifting and the reasons for differences between MORB and IAB, the samples also contribute to one of the most thorough data sets available for the Pleistocene volcanic history of submarine island-arc calderas (also see Nishimura et al., 1991), an example of deep submarine explosive eruption of tholeiitic basalt (Gill et al., 1990; Koyama et al., this volume), and background for the dredge- and Alvin-based studies of the volcanoes now exposed on the seafloor of the rift (Ikeda and Yuasa, 1989; Fryer et al., 1990; Hochstaedter et al., 1990a, 1990b).

The samples are of four kinds. The oldest consists of pre-rift Pliocene basalt scoria to rhyolite pumice from below the unconformity at Site 788, which dates rift inception. The second includes

\footnotetext{
'Taylor, B., Fujioka, K., et al., 1992. Proc. ODP, Sci. Results, 126: College Station, TX (Ocean Drilling Program).

${ }^{2}$ Earth Sciences Board and Institute of Marine Sciences, University of California, Santa Cruz, CA 95064 , U.S.A
}

the late Pleistocene arc-derived scoria and pumice, which postdate rift inception. These are from forearc Site 793, above the unconformity at volcanic arc Site 788, and in the upper half of the section at backarc Sites 790 and 791 (Fig. 1). The third kind includes the basalt lava, dikes, and breccia that form the basement of the rift at Sites 790 and 791. They are even earlier examples of Sumisu Rift BABB than the seafloor samples referenced above. The fourth is the rhyolite lava from the summit of the en echelon ridges on the Sumisu Rift seafloor. Although not sampled during Leg 126, they are discussed here in comparison with the coeval arc-derived pumices.

The silicic volcanic rocks range from dacite to rhyolite. To help the discussion, they have been divided into four increasingly differentiated categories (D, R1, R2, R3) on the basis of silica content and the concentration of compatible major and trace elements (Table 1).

\section{SAMPLE PREPARATION AND ANALYTICAL METHODS}

Lava and breccia samples from the basement of Sites 790/791 were typically $10-20 \mathrm{~cm}^{3}$ splits or mini-cores that were broken into 2-10 mm diameter chips, repeatedly ultrasonicated in distilled water, and crushed for $15 \mathrm{~min}$ in a tungsten carbide or agate ball mill. About half were crushed at sea and half at the University of California at Santa Cruz (UCSC). The tungsten carbide crushing at UCSC introduced no significant $\mathrm{Nb}$ contamination. This was demonstrated first by grinding separate aliquots of one basalt for 10,20, and $30 \mathrm{~min}$, and finding that $\mathrm{Nb}$ contents agreed within the $0.5-1.0 \mathrm{ppm}$ precision based on counting statistics. Second, analyses at UCSC of samples from adjacent pieces of core crushed in tungsten carbide at UCSC vs. crushed in agate aboard ship also agreed to within this analytical error. However, crushing in tungsten carbide apparently added $0.3-1.0 \mathrm{ppm}$ Ta to the samples.

Pumice and lithic clasts were picked from unconsolidated core sections, either at one discrete horizon, or from throughout an entire $1.5-\mathrm{m}$ core section when the stratigraphy appeared to have been disturbed by drilling. Samples that are single large clasts are identified in the tables. Some, however, were multiple but similar-appearing clasts each 1-2 cm in diameter. All clasts were scrubbed with a toothbrush and repeatedly ultrasonicated in distilled water until the 


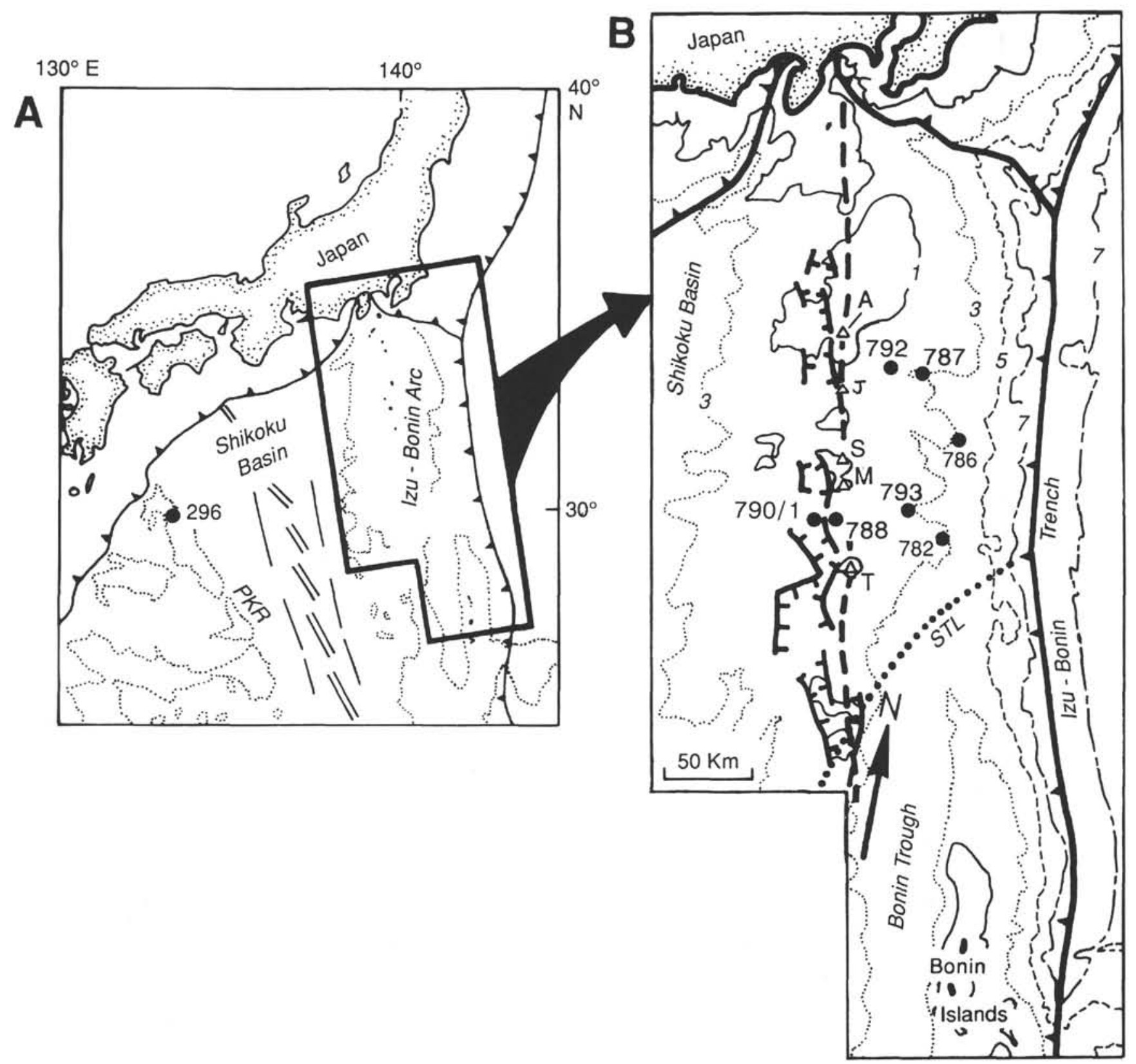

Figure 1. Map of the central Izu Arc illustrating the location of Leg 126 sites, after Hiscott and Gill (this volume). Arc volcanoes (open triangles) are, from north to south, Aogashima (A), Myojinsho (J), Sumisu Jima (S), Minami Sumisu Jima (M), and Tori Shima (T). Submarine calderas occur at or near each of these volcanoes except Tori Shima (Murakami and Ishihara, 1985).

water was no longer turbid. After drying, discolored or otherwise visibly altered clasts were discarded. In two cases from Hole 793A (Sections 126-793A-3H-6 and -4H-5), two populations of clasts from throughout an entire core section were separated on the basis of color and density, and were analyzed separately. Pumice samples were also crushed in the tungsten carbide ball mill. Most of the resulting powders were $4-25 \mathrm{~g}$, but some were $1.5-4 \mathrm{~g}$. Trace element analysis by X-ray fluorescence (XRF) was not attempted for the small samples, and few loss on ignition (LOI) measurements were made.

Major and trace element analysis by XRF followed the methodology of Stork et al. (1987), except that a dual Cr-Au tube was used for trace element analysis of the pumices, resulting in an inability to measure their $\mathrm{Mn}, \mathrm{Cr}, \mathrm{V}$, and $\mathrm{Rb}$ contents. The precision of the XRF analyses is $<1 \% 2 \sigma$ for the major elements except $\mathrm{Na}$, and $<1-4 \mathrm{ppm}$ for trace elements (see Appendix). The data are reported on an anhydrous basis with the LOI and original totals given as background information. The original totals for basalts averaged $100.14 \pm 0.97$ wt $\%$. Accuracy can be judged by the agreement for international standards reported by Stork et al. (1987), many of which were repeated during this analytical period and are within twice the precision. Representative data are in the Appendix. Agreement with shipboard results for trace elements in basalts is within 2 ppm except for $\mathrm{Sr}$ (average difference is $+11 \pm 16 \mathrm{ppm}$, with UCSC results higher), $\mathrm{Ni}(+6 \pm 3 \mathrm{ppm})$, and $\mathrm{Ba}(-9 \pm 12 \mathrm{ppm})$.

Our biggest analytical problem was sample preparation for $\mathrm{Na}$, which was measured at UCSC by XRF, using both fusion and pressed powder pellets, and by atomic absorption for a subset. Unless otherwise noted in Tables 2,5, and 7, Na results are by XRF on powder 
Table 1. Characteristics of dacites and rhyolites of the Izu Arc.

\begin{tabular}{lcccc}
\hline & Dacite & R1 & R2 & R3 \\
\hline $\mathrm{SiO}_{2}$ & $64-70$ & $70-71$ & $71-73$ & $73-75$ \\
$\mathrm{TiO}_{2}$ & $0.7-0.8$ & $0.55-0.65$ & $0.45-0.55$ & $0.37-0.50$ \\
$\mathrm{Fe}_{2} \mathrm{O}_{3}$ & $6.1-7.5$ & $4.5-5.8$ & $3.0-4.0$ & $2.6-3.0$ \\
$\mathrm{MgO}$ & $1.9-2.2$ & $1.0-1.2$ & $0.7-0.8$ & $0.4-0.6$ \\
$\mathrm{~V}(\mathrm{ppm})$ & 120 & 34 & $-11-15$ & $9-10$ \\
$\mathrm{Sc}$ & $21-24$ & $15-18$ & $11-15$ & $9-10$ \\
\hline
\end{tabular}

pellets. Based on comparison between methods and results for rock standards, our XRF analyses of basalts can be up to $0.5 \mathrm{wt} \%$ too high, and our XRF analyses of rhyolites can be $\pm 0.5 \mathrm{wt} \%$, even though our internal precision is generally $\pm 0.05-0.10 \mathrm{wt} \%$ by all three methods.

In addition, 10 samples were analyzed for 29 trace elements, including all 14 rare earth elements (REE), by inductively coupled plasma mass spectrometry (ICP-MS) at Memorial University, Newfoundland, Canada. Samples were prepared using an $\mathrm{HF}-\mathrm{HNO}_{3}$ bomb digestion and analyzed using a standard addition technique (Jenner et al., 1990). Precision and detection limits are $<50 \mathrm{ppb}(<3$ relative \%) for most elements. Exceptions at the concentrations encountered in this study are $\mathrm{Sc}, \mathrm{Rb}$, and $\mathrm{Li}( \pm 1 \mathrm{ppm}) ; \mathrm{Cs}, \mathrm{Ba}, \mathrm{Sr}$, $\mathrm{Ba}, \mathrm{Zr}$, and $\mathrm{Pb}( \pm 0.1-0.3 \mathrm{ppm})$; and $\mathrm{Nb}, \mathrm{Ta}, \mathrm{Eu}, \mathrm{Lu}, \mathrm{Th}$, and $\mathrm{U}( \pm$ 3-7 relative \%). Jenner et al. (1990) show that accuracy usually is within these precision levels. Cross-checks with UCSC XRF data for ODP and other samples show agreement of $\pm 0.5 \mathrm{ppm}$ for $\mathrm{Nb} ; \pm$ 1-2 ppm for Rb, Sc, and most La; and $\pm 5-10$ ppm or $5 \%$ for $\mathrm{Sr}$ and Ba. REE and Y usually agree to within $5 \%$, but ICP-MS data for $\mathrm{Zr}$ and Y systematically were at least $10 \%$ low for the ODP samples. In addition, even bomb digestions may have been inadequate for a few samples in which $\mathrm{Zr}$, La, and $\mathrm{Y}$ contents all were $15 \%-50 \%$ lower by ICP-MS than XRF and in which, therefore, REE contents may be underestimated. This is especially true of Samples 126-793A-3H-6a (dacite) and 126-791B-78R-1 (basalt). All trace element data reported in this chapter were obtained by XRF at UCSC, except for the 23 elements in Table 3 obtained only by ICP-MS at Memorial.

$\mathrm{The} \mathrm{Sr}$ and $\mathrm{Nd}$ isotope ratios were measured at UCSC. All samples were leached in cold $2.5 \mathrm{~N} \mathrm{HCl}$ twice for $12-24 \mathrm{hr}$ before digestion to remove seawater $\mathrm{Sr}$. Total processing blanks were $\sim 1$ nanogram $\mathrm{Sr}$ and $\sim 30$ picogram Nd. Unleached aliquots had ${ }^{87} \mathrm{Sr}{ }^{86} \mathrm{Sr}$ ratios 0.0003 0.0006 higher than leached samples, whereas ${ }^{143} \mathrm{Nd} /{ }^{144} \mathrm{Nd}$ ratios differed by only $27 \mathrm{ppm}$, which is just slightly outside analytical imprecision. Replication of $\mathrm{Sr}$ data was assessed by completely processing five samples twice, including leaching. The duplicates differ in ${ }^{87} \mathrm{Sr} /{ }^{86} \mathrm{Sr}$ by only $22 \mathrm{ppm}$ on average (the range is from 5 to $52 \mathrm{ppm}$ ). Because we are comparing in this chapter the isotopic results from UCSC with those obtained earlier at DTM for Alvin-collected samples (Hochstaedter et al., 1990b), we reanalyzed one Alvin sample (1891-7). The Sr-Nd results agree within analytical precision.

Mineral analyses were collected at UCSC with a Princeton GammaTech energy dispersive system (EDS) using a lithium-drifted detector connected to an ISI WB-6 scanning electron microscope. Spectra collection time was $200 \mathrm{~s}$, using an accelerating voltage of $15 \mathrm{kV}$, a sample current in the 300-500 nanoamp range in the Faraday cup, and a beam size of 5-10 mm. Windows used for background fits included $\mathrm{Nb}$-Ho for olivine, clinopyroxene, $\mathrm{Cr}$-spinel, and magnetite. Separate sets of background windows were used for plagioclase analyses. $\mathrm{Ge}-\mathrm{Zr}, \mathrm{Mg}-\mathrm{Cs}$, and $\mathrm{Ag}-\mathrm{Co}$ background windows were used for the $\mathrm{Na}-\mathrm{Al}, \mathrm{Si}$, and $\mathrm{Ca}-\mathrm{K}-\mathrm{Fe}$ peaks, respectively.

Concentrations were calculated relative to natural mineral standards. Oxide analyses relied on chromite and synthetic $\mathrm{TiO}_{2}$ standards. Based on replicate analyses of diopside, olivine, and orthoclase standards, the $1 \sigma$ precision is $0.71 \mathrm{~mol} \% \mathrm{En}(N=14), 0.16 \mathrm{~mol} \%$ Fo $(N=21)$, and $0.86 \mathrm{~mol} \% \mathrm{Ab}(N=10)$, respectively. Absorption of low-energy $\mathrm{Na}$ X-rays results in a $10 \%$ standard error in wt $\% \mathrm{Na}_{2} \mathrm{O}$ for feldspar.

The accuracy of the EDS results was checked by analyzing some of the same spots with a 5-spectrometer JEOL 733 wavelength dispersive electron microprobe at Stanford University. The composition of glass also was determined using this technique. The microprobe was operated at $15 \mathrm{kV}$ using a nominal 15 nanoamp sample current and a spot size of $20 \mathrm{~mm}$ for plagioclase and glass, and $10 \mathrm{~mm}$ for other minerals. EDS and microprobe results agree to within 2 $\mathrm{mol} \%$ En for clinopyroxene, $0.5 \mathrm{~mol} \%$ for olivine, and $4 \mathrm{~mol} \%$ for plagioclase. Although single oxide grains were not analyzed by both methods, analyses of two $\mathrm{Cr}$-spinels included in the same olivine grain but analyzed by the different methods are compared in Table 12 (Sample 126-791B-63R-1, $53 \mathrm{~cm}$ ).

Table 2. Major and trace element analyses of Pliocene arc pumices.

\begin{tabular}{|c|c|c|c|c|c|c|c|c|c|}
\hline \multirow[b]{2}{*}{ Hole } & \multirow{2}{*}{$\frac{\text { Sequence } 3}{788 C^{a}}$} & \multicolumn{8}{|c|}{ Sequence 2} \\
\hline & & $788 \mathrm{C}^{\mathrm{a}}$ & $788 C^{a}$ & $788 C^{a}$ & $788 \mathrm{C}$ & $788 \mathrm{C}^{\mathrm{ab} b}$ & $788 \mathrm{C}^{\mathrm{a}}$ & $788 \mathrm{C}^{\mathrm{a}}$ & $788 C^{a}$ \\
\hline Core, section & $8 \mathrm{H}-1$ & $12 \mathrm{H}-3$ & $12 \mathrm{H}-5$ & $14 \mathrm{H}-3$ & $14 \mathrm{H}-3$ & $14 \mathrm{H}-6$ & $14 \mathrm{H}-\mathrm{CC}$ & $15 \mathrm{H}-3$ & $19 \mathrm{H}-\mathrm{CC}$ \\
\hline Interval $(\mathrm{cm})$ & $67-69$ & $104-106$ & $10-13$ & $16-18$ & $43-46$ & $59-61$ & $5-15$ & $68-71$ & $10-12$ \\
\hline Age (Ma) & 2.8 & 3.1 & 3.1 & 3.1 & 3.1 & 3.2 & 3.2 & 3.2 & 3.45 \\
\hline Depth (mbsf) & 69 & 110 & 112 & 128 & 128 & 133 & 134 & 138 & 182 \\
\hline \multicolumn{10}{|c|}{ Major elements (wt\%): } \\
\hline $\mathrm{SiO}_{2}$ & 74.75 & 74.86 & 72.40 & 70.55 & 75.40 & 73.01 & 60.32 & 50.78 & 65.71 \\
\hline $\mathrm{TiO}_{2}$ & 0.32 & 0.44 & 0.52 & 0.72 & 0.26 & 0.55 & 0.92 & 1.00 & 0.84 \\
\hline $\mathrm{Al}_{2} \mathrm{O}_{3}$ & 13.51 & 13.18 & 13.04 & 13.59 & 13.07 & 13.36 & 14.25 & 19.61 & 14.41 \\
\hline $\mathrm{Fe}_{2} \mathrm{O}_{3}$ & 3.37 & 2.75 & 3.62 & 4.93 & 2.83 & 3.77 & 10.45 & 9.02 & 7.17 \\
\hline $\mathrm{MnO}$ & - & - & 0.12 & - & - & - & 0.18 & - & - \\
\hline $\mathrm{MgO}$ & 0.42 & 0.77 & 1.14 & 1.09 & 0.55 & 1.07 & 3.57 & 4.56 & 1.50 \\
\hline $\mathrm{CaO}$ & 1.94 & 2.34 & 3.15 & 3.69 & 1.90 & 3.13 & 6.45 & 11.93 & 5.24 \\
\hline $\mathrm{Na}_{2} \mathrm{O}$ & 4.16 & 3.92 & $c_{4.50}$ & $c_{4.78}$ & 4.41 & 4.01 & $c_{3.38}$ & 2.67 & 4.22 \\
\hline $\mathrm{K}_{2} \mathrm{O}$ & 1.48 & 1.65 & 1.02 & 0.71 & 1.52 & 1.00 & 0.61 & 0.26 & 0.76 \\
\hline $\mathrm{P}_{2} \mathrm{O}_{5}$ & 0.04 & 0.09 & 0.10 & 0.16 & 0.06 & 0.10 & 0.11 & 0.12 & 0.15 \\
\hline Orig LOI & - & - & 3.89 & - & - & - & 1.84 & - & - \\
\hline Orig sum & 92.65 & 92.91 & 99.60 & 98.61 & 92.34 & 91.92 & 100.90 & 97.51 & 98.88 \\
\hline \multicolumn{10}{|c|}{ Trace elements (ppm): } \\
\hline $\mathrm{Ba}$ & 119 & & 115 & 108 & & & 55 & 24 & 86 \\
\hline $\mathrm{Sr}$ & 146 & & 146 & 178 & & & 172 & 243 & 173 \\
\hline $\mathrm{Zr}$ & 204 & & 115 & 102 & & & 62 & 50 & 91 \\
\hline $\mathrm{Nb}$ & 4.0 & & 1.8 & 2.5 & & & 0.9 & 1.4 & 1.8 \\
\hline $\mathrm{La}$ & 12.6 & & 5.2 & 7.5 & & & 5.7 & 2.9 & 4.9 \\
\hline $\mathrm{Y}$ & 54 & & 46 & $51^{\circ}$ & & & 32 & 20 & 41 \\
\hline $\mathrm{Ni}$ & 3.4 & & $\begin{array}{r}40 \\
3.1\end{array}$ & 4.7 & & & 8.8 & 20.7 & 3.3 \\
\hline $\mathrm{Sc}$ & 9.1 & & 12.5 & 17.6 & & & 32.0 & 45.3 & 23.7 \\
\hline
\end{tabular}

Note: $\mathrm{LOI}=$ loss on ignition.

a Single clast analysis; remainder are multiple clast populations.

${ }^{b}$ Shipboard sample preparation and major element analyses.

${ }^{c}$ Atomic absorption analysis. 


\section{PRE-RIFT ARC VOLCANISM}

Rifting is inferred to have begun before deposition of the oldest sediments encountered at Sites 790 and 791 in the Sumisu Rift (before $1.1 \mathrm{Ma})$, and after deposition of the youngest sediments beneath the unconformity at $35.1 \mathrm{mbsf}$ at Site 788 on the $\operatorname{arc}$ (after 2.35 Ma) (B. Taylor, this volume). Our samples of pre-rift arc volcanism are from beneath the unconformity at Site 788 .

Significant volcanism in the Izu Arc resumed at about $17 \mathrm{Ma}$, shortly after cessation of spreading in the Shikoku Basin, and has continued to the present (B. Taylor, this volume). Because dense basalt had been observed from Alvin to crop out on the lower graben wall only $5 \mathrm{~km}$ west of Site 788 (Taylor et al., 1990), one of the original drilling objectives there was to obtain lavas erupted in the arc just before the most recent episode of arc rifting. However, only variably indurated pumice sands and gravels, not lavas, were recovered at Site 788. These volcaniclastic sediments are the only products of pre-rift Pliocene volcanism at this location along the arc. In retrospect, the basaltic rocks seen from Alvin are syn-rift sills in the graben wall (Hochstaedter et al., 1990a). Consequently, a more complete record of the magmatism preceding arc rifting was obtained by studying the geochemistry of the sandstones (Hiscott and Gill, this volume).

The absence of lava makes it ambiguous whether or not the volcanic front during the Neogene was along strike of Site 788 as now, or west of it at the modern remnant arc (Nishi-Shichito Ridge) from which 2.0 \pm 1.1 Ma basalt has been dredged (Yuasa, 1985). B. Taylor (pers. comm., 1990) argues from the seismic stratigraphy in the moat surrounding Sumisu Jima volcano that the moat formed before the late Miocene, so that the resumption of arc volcanism after the cessation of spreading in the Shikoku Basin occurred at the present volcanic front. If sso, the Pliocene pumices at Site 788 were erupted from centers along strike to the south or north, were deposited in a low spot between centers, and were then uplifted during arc rifting to form the unconformity at $35.1 \mathrm{mbsf}$ at Site 788 .

Nine samples of pumice were studied from below that unconformity (Tables 2-4). Stratigraphically, most are from the middle of three fines-depleted, upward-coarsening pumiceous debris flows that mark the onset of silicic volcanism near Sumisu Jima during the period from about 3.8 to $2.35 \mathrm{Ma}$ (Nishimura et al., 1991). Sequence 2 at $100-140$ mbsf is 2.9-3.15 Ma. Our samples include both the juvenile silicic pumices and one each of basalt and andesite lithic clasts from near the base of this debris flow. The juvenile pumices range from dacite to $\mathrm{R} 3$ rhyolite; generally, they are more silicic than the bulk samples of interbedded sandstone, but they have similar ratios of incompatible trace elements (Hiscott and Gill, this volume). In this one debris flow (indeed, in one section of core), the silicic pumices vary by a factor of 2 in $\mathrm{MgO}$ and $\mathrm{K}_{2} \mathrm{O}$ contents, and a factor of 3 in $\mathrm{TiO}_{2}$ and $\mathrm{P}_{2} \mathrm{O}_{5}$. In general, the silicic pumices have enrichments of alkaline earths relative to REE. One (Core 126-788C-12H-5) has a flat REE pattern marked by $\mathrm{La}-\mathrm{Ce}$ depletion and a negative Eu anomaly (Figs. 2-3). Nonetheless, their relative alkali and alkaline earth enrichments are less than in their Quaternary analogues, and $\mathrm{Cs}_{\mathrm{N}}$ $\sim \mathrm{Rb}_{\mathrm{N}}$, so that their "arc-like-ness" is muted.

Two R3 rhyolite pumices were found, one within each of the second and third debris flows. Their incompatible trace element ratios are more similar to those of the late Pleistocene rhyolite lavas erupted atop the en echelon ridges on the floor of the Sumisu Rift (see "Sumisu Rift Rhyolites" section, this chapter) than the other rhyolite pumices described above. This is most vividly illustrated by comparing the R3 rhyolite in the youngest debris flow below the unconformity (Core $126-788 \mathrm{C}-8 \mathrm{H}-1$ ) with the R3 rhyolite pumice from Core 126-788C$3 \mathrm{H}-3$ above the unconformity at Site 788 (i.e., postdating the inception of rifting) (Fig. 3B). The older sample has much higher $\mathrm{Zr} / \mathrm{Ba}$ ratios, Th + LREE (light rare earth element) enrichment rather than depletion, $\mathrm{Cs}_{\mathrm{N}}<\mathrm{Rb}_{\mathrm{N}}$, and no $\mathrm{Ba}$ or $\mathrm{Pb}$ spikes, all of which make it similar to the rift rhyolites. The second apparently rift-type rhyolite is from the second debris flow, in Core 126-788C-14H-3, but it was too small for trace element analysis by XRF. Both are unlike all other pumices or sandstones analyzed, whether pre- or post-rift in age, and whether deposited in the backarc, arc, or forearc. However, rhyolite ash with similar composition occurs at Site 792 in $0.61-0.73 \mathrm{Ma}$ sediment (Egeberg et al., this volume). The closest chemical analogues erupted in the rift, where they occur as lava, not pumice (see "Sumisu Rift Rhyolites" section, this chapter). The differences between the R3 and the R1-R2 rhyolites probably are not the result of differentiation because fractionation of observed phenocrysts cannot

Table 3. ICP-MS trace element analyses of arc and rift volcanic rocks.

\begin{tabular}{|c|c|c|c|c|c|c|c|c|c|c|c|c|c|c|c|}
\hline \multirow{3}{*}{$\begin{array}{l}\text { Hole } \\
\text { Core, section }\end{array}$} & \multicolumn{4}{|c|}{ Pliocene arc } & \multicolumn{3}{|c|}{ Pleistocene arc } & \multicolumn{8}{|c|}{ Rift samples } \\
\hline & $788 \mathrm{C}$ & $\begin{array}{l}788 \mathrm{C} \\
2 \mathrm{H}-5\end{array}$ & $788 \mathrm{C}$ & $788 \mathrm{C}$ & $793 \mathrm{~A}$ & $790 \mathrm{~B}$ & $788 \mathrm{C}$ & $790 \mathrm{C}$ & $791 \mathrm{~B}$ & $791 B$ & $791 \mathrm{~B}$ & $791 \mathrm{~B}$ & 791B & & \\
\hline & $8 \mathrm{H}-1$ & $12 \mathrm{H}-5$ & $14 \mathrm{H}-\mathrm{CC}$ & $15 \mathrm{H}-3$ & $3 \mathrm{H}-6^{\circ}$ & $10 \mathrm{H}-1^{2}$ & $3 \mathrm{H}-3$ & $24 \mathrm{R}-1$ & 55R-1 & $59 \mathrm{R}-1$ & $64 \mathrm{R}-1$ & $75 \mathrm{R}-1$ & $78 \mathrm{R}-\mathrm{I}^{\circ}$ & $1894-9^{2}$ & $1895-4^{*}$ \\
\hline V & 2.69 & 24.30 & 243.00 & 387.00 & 121.00 & 33.80 & 2.20 & 277.00 & 290.00 & 270.00 & 321.00 & 345.00 & 287.00 & 301.00 & 4.03 \\
\hline $\mathrm{Li}$ & 9.06 & 7.63 & 12.30 & 3.67 & 11.10 & 9.42 & 9.99 & 10.90 & 6.54 & 7.21 & 5.35 & 4.77 & 3.53 & 3.03 & 12.40 \\
\hline $\mathrm{Rb}$ & 15.70 & 9.14 & 7.72 & 3.31 & 9.89 & 8.04 & 6.83 & 6.52 & 3.57 & 2.62 & 1.32 & 1.32 & 1.39 & 3.74 & 21.30 \\
\hline Cs & 0.40 & 0.52 & 0.38 & 0.10 & 0.96 & 0.61 & 0.46 & 0.16 & 0.08 & 0.09 & 0.02 & 0.03 & 0.03 & 0.12 & 0.71 \\
\hline $\mathrm{Hf}$ & 5.33 & 3.37 & 1.79 & 1.29 & 2.50 & 2.82 & 2.97 & 1.62 & 1.78 & 1.58 & 1.14 & 1.28 & 1.16 & 1.24 & 5.80 \\
\hline $\mathrm{Ta}$ & 2.43 & 1.20 & 2.19 & 1.84 & 8.52 & 2.02 & 1.30 & 0.29 & 0.12 & 0.09 & 1.26 & 0.08 & 1.06 & 0.46 & 0.45 \\
\hline $\mathrm{Pb}$ & 3.50 & 3.02 & 2.02 & 1.20 & 5.62 & 6.60 & 3.27 & 6.51 & 1.39 & 1.03 & 0.67 & 2.15 & 0.91 & 0.71 & 3.26 \\
\hline Th & 1.20 & 0.47 & 0.18 & 0.22 & 0.36 & 0.47 & 0.34 & 0.37 & 0.29 & 0.23 & 0.15 & 0.18 & 0.38 & 0.21 & 1.52 \\
\hline $\mathrm{U}$ & 0.50 & 0.29 & 0.18 & 0.45 & 0.56 & 0.37 & 0.21 & 0.16 & 0.11 & 0.16 & 0.46 & 0.29 & 0.14 & 0.16 & 0.50 \\
\hline $\mathrm{La}$ & 12.30 & 5.10 & 2.69 & 2.79 & 3.69 & 4.46 & 4.12 & 6.17 & 4.28 & 3.95 & 3.25 & 3.50 & 4.38 & 2.36 & 15.40 \\
\hline $\mathrm{Ce}$ & 31.60 & 14.60 & 8.52 & 8.28 & 10.20 & 12.30 & 12.30 & 14.20 & 11.40 & 10.30 & 7.90 & 9.34 & 10.80 & 6.84 & 40.90 \\
\hline $\operatorname{Pr}$ & 4.69 & 2.44 & 1.50 & 1.42 & 1.79 & 2.11 & 2.14 & 2.38 & 1.87 & 1.76 & 1.45 & 1.57 & 1.59 & 1.19 & 6.28 \\
\hline $\mathrm{Nd}$ & 21.80 & 12.70 & 8.26 & 7.35 & 9.61 & 11.40 & 11.50 & 11.60 & 9.42 & 8.81 & 7.63 & 8.03 & 7.30 & 6.37 & 28.90 \\
\hline $\mathrm{Sm}$ & 5.83 & 4.18 & 2.93 & 2.38 & 3.20 & 3.84 & 3.98 & 3.15 & 2.79 & 2.42 & 2.31 & 2.37 & 2.06 & 2.20 & 7.84 \\
\hline $\mathrm{Eu}$ & 1.54 & 1.26 & 1.13 & 0.93 & 1.01 & 1.21 & 1.34 & 1.16 & 1.05 & 1.02 & 0.91 & 0.92 & 0.81 & 0.88 & 2.03 \\
\hline Gd & 7.03 & 5.45 & 4.06 & 3.06 & 4.30 & 5.12 & 5.39 & 3.92 & 3.36 & 3.33 & 2.93 & 3.16 & 2.34 & 2.66 & 8.91 \\
\hline $\mathrm{Tb}$ & 1.14 & 0.93 & 0.72 & 0.52 & 0.76 & 0.91 & 0.98 & 0.61 & 0.55 & 0.54 & 0.48 & 0.48 & 0.37 & 0.45 & 1.52 \\
\hline Dy & 7.91 & 6.39 & 4.96 & 3.44 & 5.14 & 6.15 & 6.81 & 3.84 & 3.58 & 3.34 & 3.23 & 3.27 & 2.47 & 3.00 & 10.20 \\
\hline Ho & 1.67 & 1.42 & 1.05 & 0.73 & 1.12 & 1.35 & 1.49 & 0.78 & 0.76 & 0.70 & 0.67 & 0.69 & 0.50 & 0.63 & 2.19 \\
\hline $\mathrm{Er}$ & 5.07 & 4.23 & 3.08 & 2.16 & 3.40 & 4.20 & 4.57 & 2.20 & 2.19 & 2.06 & 2.01 & 1.98 & 1.39 & 1.81 & 6.75 \\
\hline $\mathrm{Tm}$ & 0.78 & 0.64 & 0.47 & 0.30 & 0.51 & 0.62 & 0.70 & 0.34 & 0.33 & 0.29 & 0.29 & 0.28 & 0.20 & 0.26 & 0.98 \\
\hline $\mathrm{Yb}$ & 5.29 & 4.47 & 3.17 & 2.02 & 3.45 & 4.17 & 4.77 & 2.08 & 2.00 & 1.85 & 1.83 & 1.85 & 1.21 & 1.68 & 6.72 \\
\hline $\mathrm{Lu}$ & 0.83 & 0.68 & 0.48 & 0.30 & 0.53 & 0.65 & 0.75 & 0.31 & 0.32 & 0.27 & 0.29 & 0.28 & 0.18 & 0.26 & 1.04 \\
\hline
\end{tabular}

\footnotetext{
'See Hochstaedter, et al. (1990a, 1990b) concerning Alvin samples 1894-9 (basalt) and 1895-4 (rhyolite).

b Sample 126-793A-3H-6, 0-150 cm; rhyolite.

'Sample 126-790B-10H-1, 0-35 cm.

${ }^{d}$ Sample 126-791B-78R-1, 113-115 cm.
} 
Table 4. Sr and Nd isotopic analyses of arc and rift volcanic rocks.

\begin{tabular}{|c|c|c|c|}
\hline Sample & ${ }^{87} \mathrm{Sr} r^{86} \mathrm{Sr}$ & ${ }^{143} \mathrm{Nd} /{ }^{144} \mathrm{Nd}$ & $\varepsilon_{\mathrm{Nd}}$ \\
\hline \multicolumn{4}{|l|}{$\begin{array}{l}\text { Pliocene pumices: } \\
126-788 \mathrm{C}-12 \mathrm{H}-5\end{array}$} \\
\hline $126-788 \mathrm{C}-14 \mathrm{H}-\mathrm{CC}$ & $0.703483 \pm 11$ & $0.513091 \pm 6$ & $\overline{8.9}$ \\
\hline & $0.703110 \pm 14$ & $0.513070 \pm 16$ & 8.4 \\
\hline \multicolumn{4}{|l|}{ Pleistocene pumices: } \\
\hline 126-793A-3H-6 & $\begin{array}{l}0.703596 \pm 8 \\
0.703601 \pm 10\end{array}$ & $0.513104 \pm 9$ & 9.0 \\
\hline $126-790 \mathrm{~B}-10 \mathrm{H}-1$ & $0.703526 \pm 10$ & $0.513103 \pm 8$ & 9.0 \\
\hline $126-788 \mathrm{C}-3 \mathrm{H}-3$ & $0.703409 \pm 11$ & $0.513102 \pm 6$ & 9.0 \\
\hline \multicolumn{4}{|l|}{ Rift bas } \\
\hline & $\begin{array}{l}0.703015 \pm 10 \\
0.703298 \pm 10\end{array}$ & $0.513066 \pm 7$ & 8.3 \\
\hline $126-791 B-55 R-1$ & $0.702919 \pm 13$ & 二 & 二 \\
\hline 126-791B-59R-1 & $\begin{array}{l}0.702940 \pm 12 \\
0.702948 \pm 10\end{array}$ & $0.513 \overline{100} \pm 10$ & $\overline{9.0}$ \\
\hline & $0.702956 \pm 11$ & & \\
\hline 126-791B-63R-1 & $0.703036 \pm 11$ & $0.513094 \pm 8$ & 8.9 \\
\hline $126-791 \mathrm{~B}-6$ & $\begin{array}{l}0.703001 \pm 8 \\
0.703053+10\end{array}$ & $0.513088 \pm 7$ & 8.8 \\
\hline u & $0.703699 \pm 30$ & $0.513115 \pm 7$ & 9.3 \\
\hline \multicolumn{4}{|l|}{ Alvin } \\
\hline $1891-7$ & $0.702990 \pm 7$ & $0.513043 \pm 19$ & 7.5 \\
\hline DTM & $0.703023 \pm 11$ & $0.513012 \pm 21$ & 7.5 \\
\hline
\end{tabular}

Note: Errors are 2 standard errors on mean of $80-150$ ratios, in ppm. $\varepsilon_{\mathrm{Nd}}$ relative to 0.512638 for bulk earth. The letter "u" indicates unleached; all others were leached before digestion. "DTM" result is from Hochstaedter, et al. (1990b).

account for the differences in trace element ratios noted above. Instead, these differences are the same as those between rift and arc basalts and, therefore, reflect parentage.

Two lithic clasts also were analyzed. The basalt (Sample 126$788 \mathrm{C}-15 \mathrm{H}-3,68-71 \mathrm{~cm}$; about $3.1 \mathrm{Ma}$ ) is especially interesting because of its partial similarity in trace element concentrations and $\mathrm{Sr}-\mathrm{Nd}$ isotope ratios to the later basalts of the Sumisu Rift seafloor (SRB), and its difference from Quaternary basalts of the Izu Arc. It has very low concentrations of incompatible trace elements, including no relative enrichment in $\mathrm{Ba}$ or $\mathrm{Pb}$, and a differently but distinctively shaped REE pattern with a maximum between Pr and Sm (Figs. 2-3). $\mathrm{Ce} / \mathrm{Pb}$ ratios, for example, remain MORB-like. The enrichment in LREE and Eu, and the depletion in Ce, are similar to characteristics of the later SRB (Hochstaedter et al., 1990b). Its ${ }^{87} \mathrm{Sr} /{ }^{86} \mathrm{Sr}$ ratio $(0.70311)$ is lower than that of the juvenile silicic pumice $(0.70344)$ and similar to that of SRB from the graben wall (Hochstaedter et al., 1990b). The difference in $\varepsilon_{\mathrm{Nd}}$ is smaller but analytically significant $(+8.4$ vs. +9.0). Nonetheless, the similarity to SRB is incomplete; the high $\mathrm{Al}$ and $\mathrm{Ca}$ and low $\mathrm{Fe}$ and $\mathrm{Ti}$ of the lithic basalt clast suggest a more arc-like differentiation history. In contrast, the andesite lithic clast appears cogenetic with the more abundant silicic pumices. Both the lithic andesite clast and the juvenile rhyolite clasts have $\mathrm{Sr}$ and, in the case of the andesite, $\mathrm{Nd}$ isotopic compositions identical to those of Quaternary andesites from the Izu Arc (Table 4).

To summarize, the geochemical characteristics of the volcanism that immediately predated the inception of rifting can be inferred only from pumice clasts and sandstones from below the unconformity at Site 788. Most clasts are dacite to rhyolite, and most are enriched in $\mathrm{Pb}$ and alkaline earths, yet depleted in LREE and high field strength elements (HFSE) relative to heavy rare earth elements (HREE). However, these arc-like attributes are less extreme than in basalts to rhyolites of the Quaternary arc. One basalt lithic clast, which was deposited $1 \mathrm{~m} . \mathrm{y}$. before a rift started to form at about $2 \mathrm{Ma}$, has many of the geochemical characteristics of the eventual backarc basin basalt source, although the basalt did not differentiate in the same way. The most differentiated rhyolites from near the top of the section also are chemically more similar to rhyolites of the eventual rift rather than to most or all of those erupted from the arc. These rhyolites were deposited about $2.6 \mathrm{Ma}$ and also predate rift inception.

\section{POST-RIFT-INCEPTION ARC VOLCANISM}

The magma eruption rate in the Izu Arc has increased during backarc rifting. At Sites 790 and 791 where age constraints are the best, eruption of coarse pumice has been common only during the last $130,000 \mathrm{yr}$. The geochemical characteristics of this late Quaternary volcanism have been studied by analyzing glass shards from ash layers (Rodolfo et al., this volume; Egeberg et al., this volume), volcanic sands (Hiscott and Gill, this volume), and pumice clasts (this chapter; Nishimura et al., this volume). The pumice clasts are the least abundant but most reliable records of magma composition at nearby submarine calderas, which are, from north to south, Sumisu Jima, Minami Sumisu Jima, and Tori Shima (Fig. 1). Our samples are from Sites 788, 790, 791, and 793 .

We analyzed 27 Pleistocene pumices, mostly from sediments younger than 200,000 yr (Tables 3-5). Three are basalt scoria from sediments that are about 2-600 k.y. old from Sites 790 and 791 . They are even more similar in composition to Sumisu Rift basalt lavas of similar age that crop out on the modern floor of the rift than is the basaltic lithic clast described above. Consequently, we think that they are examples of explosively erupted magmas from the rift rather than from the arc, somewhat similar in mode of eruption to the explosion breccia encountered at the base of Site 791 (Gill et al., 1990). Sediments above and below thick Pumice Unit III at both Sites 790 and 791 (discussed below) have mafic compositions, the trace element patterns of which are similar to those of SRB (Hiscott and Gill, this volume).

The rest of the pumices consist of arc-derived dacite and rhyolite. Many of those at Sites 790 and 791 can be correlated and define five large pumice eruptions at about 1, 31, 61, 67, and 131 ka (Pumice Units I to V, respectively; Nishimura et al., 1991). Quaternary pumices from the other sites are known only to be younger than $275 \mathrm{ka}$ and cannot be correlated with these five eruptions in detail. However, the late Quaternary pumices from arc Site 788 are most like Pumice Unit $\mathrm{I}$, with an abundance of $\mathrm{R} 3$ rhyolite.

Almost as much variation exists within each pumice deposit as do differences between them. Both analyzed samples from Pumice Unit IV are R2 rhyolites (Table 5 and Nishimura et al., this volume). Units II and III contain both R1 and R2 rhyolites, and Unit I contains both R2 and R3 rhyolites. Dacites are absent from the backarc sites but occur in both the arc and forearc sites. R3 rhyolites are the least common, occurring only in the youngest horizons at Sites 788 and 790. Dacite and R2 rhyolite pumices coexist in the same core sections at least twice at Site 793 (Cores 126-793A-3H-6 and -4H-5; see Table 5). Although this range may reflect mixtures of juvenile and lithic components, individual silicic eruptions in the Izu Arc can yield pumices that range from mafic dacite to R1 rhyolite (e.g., the 1952 eruption of Miyojinsho; see Table 6), so the distribution may be primary. In no site is there a stratigraphic pattern in the chemical composition of pumice.

All the silicic pumices are characterized by very low concentrations of $\mathrm{K}_{2} \mathrm{O}$ and other incompatible elements, including HFSE and LREE as well as alkalis and alkaline earths (Figs. 4 and 5). Although they are not as potash-poor as are some of the glass shards in Pleistocene ash layers (Rodolfo et al., this volume), they are uniformly "trondhjemitic" in composition. The concentrations of all compatible elements decrease from dacite to R2 rhyolite, but incompatible element concentrations (especially alkalis, LREE, HFSE, and Th) are notably erratic. The $\mathrm{Cs} / \mathrm{Rb}, \mathrm{Ba} / \mathrm{K}$, and $\mathrm{Pb} / \mathrm{Ce}$ ratios are consistently high, as is common in oceanic arc basalts and andesites, and higher than in the Pliocene pumices. The REE patterns are uniformly LREE-depleted, approximately the same as in the Pliocene pumices (Fig. 5). ${ }^{87} \mathrm{Sr} /{ }^{86} \mathrm{Sr}$ ratios are $0.7034-0.7036$, similar to or slightly less than those of Quaternary Izu Arc volcanics (Notsu et al., 1983) and most of the Pliocene pumices. $\varepsilon_{\mathrm{Nd}}$ is +9.0 and is similar to that found in Quaternary Izu Arc basalts (Nohda and Wasserburg, 1981). 


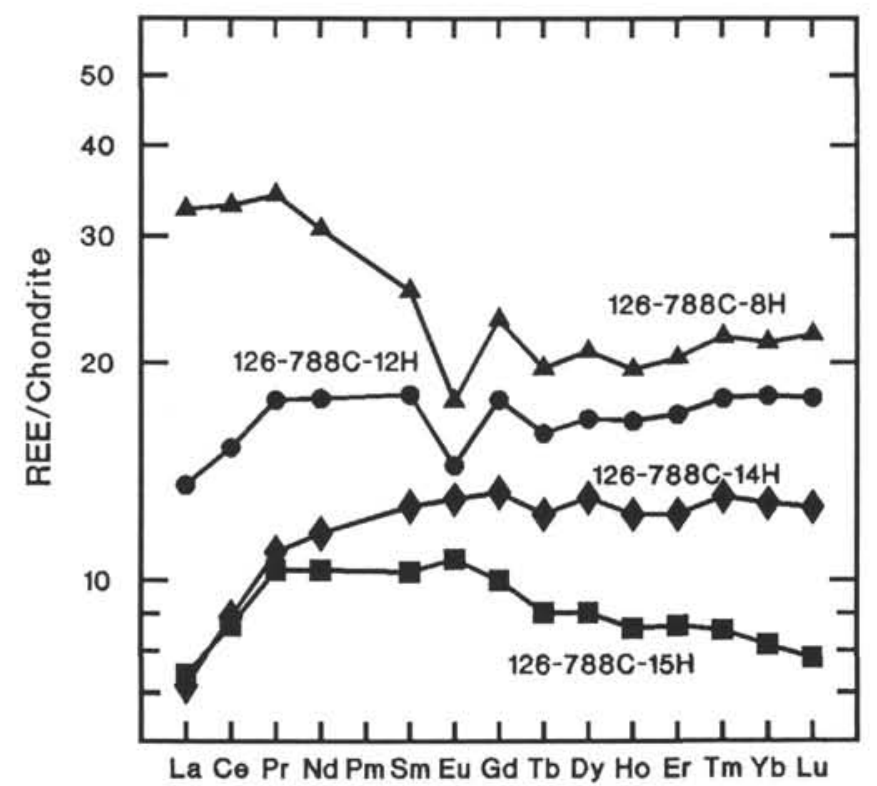

Figure 2. Chondrite-normalized REE patterns for pre-rift arc volcanics from Site 788. Normalization values are from Evensen et al. (1978).

These characteristics are shared by the other presumably Quaternary rhyolites that have been dredged from the Izu Arc (Ikeda and Yuasa, 1989). Consequently, they seem representative of the voluminous Pleistocene volcanic materials of the central Izu Arc. However, they differ from the subaerial dacites to rhyolites erupted in the northern Izu Arc that have higher concentrations of incompatible elements despite lower $\mathrm{Ti}, \mathrm{Na}$, and $\mathrm{HREE}$ at similar $\mathrm{SiO}_{2}$ and $\mathrm{MgO}$ contents (Table 6).

Rhyolites that are enriched in LREE $\pm \mathrm{Nb}$-Ta also may erupt at the volcanic front of the Izu Arc, but the evidence is inconclusive. Two
Pliocene LREE-enriched R3 rhyolite pumices from Site 788 were discussed in the previous section. Two 0.1-Ma turbidites from Sites 790 and 791 have intermediate compositions and flat REE patterns (Hiscott and Gill, this volume), as do the hemipelagic muds at these sites (Nishimura et al., this volume). Because both the basaltic and rhyolitic magmas of the rift are LREE-enriched (Hochstaedter et al., $1990 \mathrm{~b}$ ), these pumices, turbidites, and muds may include material erupted in the rift rather than arc. The arc, however, is expected to be a major source of detritus at all three sites. Finally, forearc ash at Site 792 includes four 8-19 cm-thick, 0.6-0.7 Ma ash layers which are slightly enriched in LREE and Ta (part of the T1 category of Egeberg et al., this volume). Although the ashes imply shallow-water eruption, none of these four sediment types requires that LREE-enriched magmas erupted $a t$ the volcanic front rather than behind it.

The Leg 126 Pleistocene samples have higher concentrations of elements commonly enriched in arc magmas, such as $\mathrm{Ba}, \mathrm{Cs}$, and $\mathrm{Pb}$, especially relative to LREE, than do the Pliocene arc samples discussed above, even though $\mathrm{Zr} / \mathrm{Y}$ ratios are lower in both the Pleistocene pumice clasts and sandstones (Hiscott and Gill, this volume). Thus, arc-like characteristics increased with time in the highly differentiated magmas, being lower in the arc before the inception of backarc rifting and greater after inception began.

\section{EARLIEST VOLCANISM IN THE SUMISU RIFT}

The basement of Sites 790 and 791 consists largely of basaltic rocks that formed earlier in the history of backarc basin development than any rocks hitherto available from any other backarc. At both sites this basement lies beneath sediments about 1.1 Ma (Unit II). Although the age of inception of backarc basin development is somewhat ambiguous, both conceptually and temporally, the results of Leg 126 suggest that the Sumisu Rift began to deepen rapidly between 1 and $2 \mathrm{Ma}$ (B. Taylor, this volume), so that our samples formed within the first $0.5-1.0 \mathrm{~m} . \mathrm{y}$. of rift development.

About 40 samples from almost all igneous stratigraphic units at both sites have been analyzed; the results are given in Tables 3,4 , and
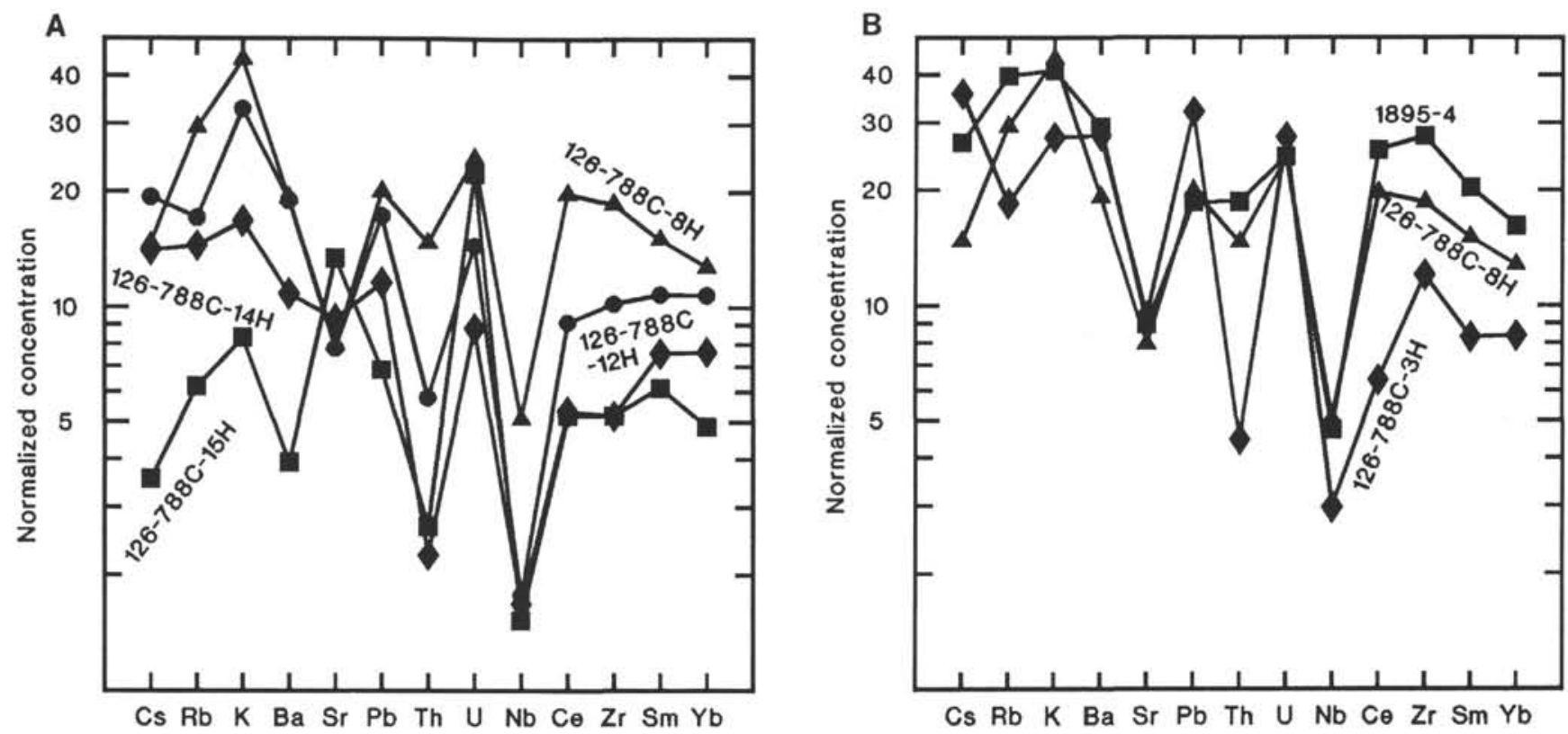

Figure 3. A. Normalized extended trace element diagram for pre-rift arc volcanics from Site 788. Normalization values are as for Figure 2 and from Hofmann (1988). B. Normalized extended trace element diagram for R3 rhyolites. Section $126-788 \mathrm{C}-8 \mathrm{H}$ is a pre-rift Pliocene arc pumice; Section 126-788C-3H is a post-rift-inception Pleistocene arc pumice; and 1895-4 is a Pleistocene Sumisu Rift rhyolite collected using Alvin. 
Table 5. Major and trace element analyses of anhydrous Pleistocene pumices.

\begin{tabular}{|c|c|c|c|c|c|c|c|c|c|c|c|c|c|c|}
\hline \multirow[b]{2}{*}{$\begin{array}{l}\text { Hole } \\
\text { Core, section } \\
\text { IIterval (cm) } \\
\text { Depth (mbsf) }\end{array}$} & \multirow[b]{2}{*}{$\begin{array}{c}793 \mathrm{~A}^{\mathrm{b}} \\
1 \mathrm{~A}-2 \\
14-17 \\
1.5\end{array}$} & \multirow[b]{2}{*}{$\begin{array}{c}793 \mathrm{~A}^{\mathrm{b}} \\
2 \mathrm{H}-3 \\
115-118 \\
8\end{array}$} & \multirow[b]{2}{*}{$\begin{array}{c}793 \mathrm{~A}^{\mathrm{b}} \\
2 \mathrm{H}-4 \\
2-5 \\
8\end{array}$} & \multirow[b]{2}{*}{$\begin{array}{l}793 \mathrm{~A} \\
3 \mathrm{H}-6 \\
1-150 \\
21\end{array}$} & \multirow[b]{2}{*}{$\begin{array}{c}793 \mathrm{~A} \\
3 \mathrm{H}-6 \\
1-150 \\
21\end{array}$} & \multirow[b]{2}{*}{$\begin{array}{c}793 \mathrm{~A} \\
4 \mathrm{H}-1 \\
35-40 \\
23\end{array}$} & \multirow[b]{2}{*}{$\begin{array}{c}793 \mathrm{~A} \\
4 \mathrm{H}-2 \\
137-138 \\
26\end{array}$} & \multirow[b]{2}{*}{$\begin{array}{l}793 \mathrm{~A} \\
4 \mathrm{H}-3 \\
65-75 \\
27\end{array}$} & \multirow[b]{2}{*}{$\begin{array}{l}793 \mathrm{~A} \\
4 \mathrm{H}-4 \\
42-44 \\
28\end{array}$} & \multirow[b]{2}{*}{$\begin{array}{l}793 \mathrm{~A} \\
4 \mathrm{H}-5 \\
0-150 \\
30\end{array}$} & \multirow[b]{2}{*}{$\begin{array}{l}793 \mathrm{~A} \\
4 \mathrm{H}-5 \\
0-150 \\
30\end{array}$} & \multicolumn{3}{|c|}{ Sequence 4} \\
\hline & & & & & & & & & & & & $\begin{array}{l}788 \mathrm{C}^{b} \\
1 \mathrm{H}-1 \\
90-92 \\
5\end{array}$ & $\begin{array}{c}788 \mathrm{C} \\
2 \mathrm{H}-1 \\
30-90 \\
14\end{array}$ & $\begin{array}{c}788 \mathrm{C}^{b} \\
3 \mathrm{H}-3 \\
10-12 \\
23\end{array}$ \\
\hline Orig. sum & 95.37 & 96.59 & 94.11 & 98.29 & 94.68 & 95.50 & 98.10 & 98.01 & 98.85 & 98.83 & 94.76 & 94.72 & 90.66 & 95.10 \\
\hline $\begin{array}{l}\text { Trace elements (ppm): } \\
\mathrm{Ba} \\
\mathrm{Sr} \\
\mathrm{Zr} \\
\mathrm{Nb} \\
\mathrm{La} \\
\mathrm{Y} \\
\mathrm{Ni} \\
\mathrm{Sc}\end{array}$ & $\begin{array}{c}185 \\
149 \\
111 \\
1.9 \\
1.9 \\
37 \\
2.8 \\
11.2\end{array}$ & $\begin{array}{l}181 \\
157 \\
106 \\
1.4 \\
2.2 \\
41 \\
3.3 \\
13.9\end{array}$ & & $\begin{array}{c}168 \\
172 \\
117 \\
1.4 \\
4.2 \\
45 \\
1.7 \\
11.3\end{array}$ & $\begin{array}{l}357 \\
245 \\
167 \\
2.4 \\
9.6 \\
64 \\
\frac{21.3}{21.3}\end{array}$ & $\begin{array}{c}161 \\
162 \\
96 \\
1.0 \\
2.9 \\
44 \\
2.6 \\
12.9\end{array}$ & $\begin{array}{c}139 \\
167 \\
85 \\
1.4 \\
5.3 \\
36 \\
5.2 \\
22.4\end{array}$ & $\begin{array}{c}155 \\
161 \\
98 \\
0.0 \\
2.5 \\
41 \\
3.5 \\
17.6\end{array}$ & $\begin{array}{c}145 \\
167 \\
78 \\
1.3 \\
2.9 \\
34 \\
4.0 \\
20.4\end{array}$ & $\begin{array}{c}144 \\
168 \\
88 \\
0.9 \\
3.3 \\
37 \\
6.9 \\
21.9\end{array}$ & $\begin{array}{c}149 \\
156 \\
90 \\
0.5 \\
4.0 \\
41 \\
2.2 \\
11.1\end{array}$ & $\begin{array}{c}119 \\
131 \\
89 \\
1.8 \\
4.0 \\
433 \\
3.2 \\
10.1\end{array}$ & $\begin{array}{c}232 \\
172 \\
72 \\
1.0 \\
2.5 \\
34 \\
8.2 \\
22.0\end{array}$ & $\begin{array}{c}122 \\
144 \\
96 \\
0.7 \\
2.9 \\
47 \\
2.4 \\
10.1\end{array}$ \\
\hline $\begin{array}{l}\text { Major elements (wt): } \\
\mathrm{SiO}_{2} \\
\mathrm{TiO}_{2} \\
\mathrm{Al}_{2} \mathrm{O}_{3} \\
\mathrm{Fe}_{2} \mathrm{O}_{3} \\
\mathrm{MnO} \\
\mathrm{MgO} \\
\mathrm{MaO} \\
\mathrm{Na}_{22} \mathrm{O} \\
\mathrm{K}_{2} \mathrm{O} \\
\mathrm{P}_{2} \mathrm{O}_{5} \\
\mathrm{Orig} \text {. LOI } \\
\text { Orig. sum }\end{array}$ & $\begin{array}{r}49.19 \\
1.12 \\
16.87 \\
11.23 \\
\overline{8.01} \\
10.22 \\
2.78 \\
0.35 \\
0.23 \\
98 . \overline{98.82}\end{array}$ & $\begin{array}{r}49.09 \\
1.07 \\
16.43 \\
11.23 \\
0.16 \\
8.12 \\
10.89 \\
2.44 \\
0.37 \\
0.19 \\
99.81\end{array}$ & $\begin{array}{r}72.13 \\
0.43 \\
13.55 \\
3.83 \\
0.11 \\
0.81 \\
2.29 \\
5.47 \\
1.30 \\
0.08 \\
2.11 \\
99.06\end{array}$ & $\begin{array}{r}70.57 \\
0.56 \\
13.62 \\
4.21 \\
0.14 \\
1.02 \\
3.87 \\
5.16 \\
0.75 \\
0.11 \\
3.80 \\
100.26\end{array}$ & $\begin{array}{r}70.44 \\
0.60 \\
13.59 \\
4.54 \\
1.02 \\
3.84 \\
5.11 \\
0.73 \\
0.13 \\
95.98\end{array}$ & $\begin{array}{r}72.66 \\
0.60 \\
13.37 \\
3.85 \\
0.15 \\
0.79 \\
3.55 \\
4.70 \\
0.63 \\
0.10 \\
2.96 \\
99.85\end{array}$ & $\begin{array}{r}69.86 \\
0.62 \\
14.00 \\
4.82 \\
0.14 \\
1.10 \\
4.09 \\
4.46 \\
0.77 \\
0.14 \\
4.25 \\
99.59\end{array}$ & $\begin{array}{r}73.38 \\
0.48 \\
13.16 \\
3.74 \\
0.12 \\
0.86 \\
3.12 \\
4.18 \\
0.87 \\
0.09 \\
3.72 \\
99.98\end{array}$ & $\begin{array}{r}73.08 \\
0.40 \\
13.36 \\
3.55 \\
0.13 \\
0.84 \\
2.98 \\
4.97 \\
0.91 \\
0.07 \\
0.38 \\
100.29\end{array}$ & $\begin{array}{r}70.78 \\
0.60 \\
13.45 \\
4.81 \\
0.96 \\
3.83 \\
4.72 \\
0.68 \\
0.16 \\
94.74\end{array}$ & $\begin{array}{r}50.05 \\
0.97 \\
18.53 \\
9.64 \\
5.72 \\
11.63 \\
2.90 \\
0.41 \\
0.16 \\
97.24\end{array}$ & & & \\
\hline $\begin{array}{l}\text { Trace elements (ppm): } \\
\mathrm{Ba} \\
\mathrm{Sr} \\
\mathrm{Zr} \\
\mathrm{Nb} \\
\mathrm{La} \\
\mathrm{Y} \\
\mathrm{Ni} \\
\mathrm{Sc}\end{array}$ & & $\begin{array}{c}42 \\
222 \\
61 \\
3.4 \\
21 \\
102 \\
-\end{array}$ & 165 & $\begin{array}{l}145 \\
174 \\
84 \\
2.4 \\
2.4 \\
41 \\
2.2 \\
14.8\end{array}$ & $\begin{array}{c}160 \\
169 \\
94 \\
2.0 \\
6.7 \\
43 \\
1.3 \\
14.8\end{array}$ & $\begin{array}{c}126 \\
173 \\
84 \\
3.3 \\
4.4 \\
42 \\
3.6 \\
15.5\end{array}$ & $\begin{array}{l}127 \\
81 \\
2.2 \\
10.5 \\
42 \\
2.6 \\
14.8\end{array}$ & & $\begin{array}{c}168 \\
164 \\
93 \\
0.6 \\
3.2 \\
45 \\
3.6 \\
12.9\end{array}$ & & $\begin{array}{c}50 \\
247 \\
56 \\
4.4 \\
5.0 \\
20 \\
85.6 \\
42.2\end{array}$ & & & \\
\hline
\end{tabular}

Note: $\mathrm{LOI}=$ loss on ignition.

-Shipboard sample preparation and major element analyses.

b Single clast analyses; remainder are multiple clast populations.

cAtomic absorption analysis.

"Roman numbered "units" are the coarse pumices at Sites 790/791 discussed in the text.

7. Broadly speaking, all are BABB and similar to the younger Sumisu Rift basalts (SRB), which are exposed on the Sumisu Rift seafloor and previously had been sampled by means of dredging and submersible recovery (Ikeda and Yuasa, 1989; Fryer et al., 1990; Hochstaedter et al., 1990a, 1990b).

The basement samples can be grouped into four broad categories. The first consists of the basement at Site 790 and the lavas at the top of the Site 791 basement (791-t: igneous stratigraphic units 2, 3, 5, 6, 7 , and 10). The second (791-m) consists of the main breccia unit of Site 791 ("mousse": igneous stratigraphic units 11, 12, and 14). The third (791-d) consists of the dikes that crosscut the basement of Site 791 (igneous stratigraphic units $4,8,15,17$, and 29). The fourth (791-b) is the generally altered material beneath the mousse at the bottom of Site 791. The range of differentiation in the first two categories extends from about $\mathrm{Mg} \# 63$ to $47, \mathrm{MgO}=8.5-4.7 \mathrm{wt} \%$, $\mathrm{Ni}=150-10 \mathrm{ppm}, \mathrm{Cr}=270-20 \mathrm{ppm}$, and $\mathrm{Sc}=40-30 \mathrm{ppm}$. This is approximately the same range as on the modern Sumisu Rift floor (Hochstaedter et al., 1990a) and at Site 809 (ODP Leg 132) on one of the exposed lava ridges (Storms, Natland, et al., 1991).

\section{The Lavas (Site 790 and Group 791-t)}

All lava samples are basalts with the phenocryst assemblage spinel $(<1$ vol\%) $<$ olivine $(1 \%-3 \%)<$ plagioclase $(5 \%-20 \%)$ (Table 8$)$. Augite saturation is reached in Group 791-t (Unit 2) and in one sample from Site 790 , at between 6 and $7 \mathrm{wt} \% \mathrm{MgO}$. Magnetite-saturation (microphe- nocrysts $>0.1 \mathrm{~mm}$ diameter) is reached within the same range of $\mathrm{MgO}$ contents as augite saturation. Representative mineral analyses are given in Tables 9-13 for variably differentiated samples. (Only the entries for Core 126-791B-53R-1 are from a Leg 126 lava. Those for Cores 126-791B-60R-1 and $-63 R-1$ are from clasts in the breccia described in the next section, and those for 1896-1 are from an Alvin-collected lava described by Hochstaedter et al. [1990a]. The four host rocks have $\mathrm{MgO}$ contents of $8.3,7.8,5.8$, and $4.6 \mathrm{wt} \%$, respectively.)

Olivine phenocrysts have $\mathrm{Fo}_{76-88}$ cores that correlate positively with host rock $\mathrm{Mg \#} \mathrm{(Fig.} \mathrm{6).} \mathrm{The} \mathrm{rims} \mathrm{and} \mathrm{host} \mathrm{lavas} \mathrm{are} \mathrm{not} \mathrm{in}$ equilibrium unless $\mathrm{K}_{\mathrm{D}}=0.35$, where $\mathrm{K}_{\mathrm{D}}$ is the iron-magnesium exchange reaction constant for olivine-liquid. A more likely explanation is that $\mathrm{K}_{\mathrm{D}}=0.30$ and some of the olivine is accumulative, especially in the more differentiated samples. However, the lack of glass precludes further quantification of $\mathrm{K}_{\mathrm{D}}$ or oxygen fugacity $\left(\mathrm{fO}_{2}\right)$.

Plagioclase cores are $\mathrm{An}_{83-95}$ except in the most differentiated lavas, in which sieved cores reach $\mathrm{An}_{74}$. Rims are up to $5 \mathrm{~mol} \%$ more sodic than cores, and zoning is predominantly normal. Most phenocrysts are clear, and sieved crystals containing glass inclusions are common only in the more differentiated, augite-saturated samples. Augite is the only pyroxene; no crystals or rims of pigeonite or orthopyroxene were discovered, even in the most differentiated samples.

The ubiquitous chromite inclusions have $\mathrm{Cr}$-numbers $(\mathrm{Cr} \#=$ $\mathrm{Cr} /(\mathrm{Cr}+\mathrm{Al})$ ratios $)$ of $0.35-0.47$, which go through a maximum as their host olivines change from $\mathrm{Fo}_{88}$ to $\mathrm{Fo}_{76}$ (Fig. 7A). The $\mathrm{Cr}$-numbers are similar to those in spinels in MORB, which have the same 
Table 6. Representative chemical analyses of Quaternary dacites to rhyolites from the Izu-Bonin Arc.

\begin{tabular}{|c|c|c|c|c|c|c|c|c|c|}
\hline \multirow[b]{2}{*}{ Major elements (wt\%): } & \multicolumn{2}{|c|}{ Higashi-Izu } & \multirow{3}{*}{ Niijima } & \multirow{2}{*}{ Kozushima } & \multicolumn{2}{|c|}{ Miyojinsho } & \multirow{2}{*}{ Aoga Rift } & \multicolumn{2}{|c|}{ Sumisu-Jima } \\
\hline & & & & & & & & & \\
\hline $\mathrm{SiO}_{2}$ & 68.80 & 73.60 & & & 63.62 & 69.07 & & 68.63 & 73.47 \\
\hline $\mathrm{TiO}_{2}$ & 0.34 & 0.36 & 0.13 & 0.20 & 0.79 & 0.47 & 0.35 & 0.74 & 0.29 \\
\hline $\mathrm{Al}_{2} \mathrm{O}_{3}$ & 15.60 & 14.11 & 15.05 & 13.57 & 16.18 & 14.73 & 13.20 & 13.80 & 12.34 \\
\hline $\mathrm{Fe}_{2} \mathrm{O}_{3}$ & 1.62 & 0.96 & 0.58 & 0.95 & 3.15 & 2.17 & 0.82 & 1.72 & 0.48 \\
\hline $\mathrm{FeO}$ & 2.24 & 1.35 & 1.12 & 0.55 & 3.82 & 2.59 & 2.37 & 3.31 & 1.41 \\
\hline $\mathrm{MnO}$ & 0.09 & 0.08 & 0.03 & 0.08 & 0.18 & 0.12 & 0.13 & 0.19 & 0.10 \\
\hline $\mathrm{MgO}$ & 1.67 & 0.75 & 0.72 & 0.36 & 2.79 & 1.29 & 0.98 & 1.21 & 0.72 \\
\hline $\mathrm{CaO}$ & 4.00 & 2.36 & 1.40 & $\begin{array}{l}1.00 \\
1.62\end{array}$ & 6.15 & 5.13 & 2.54 & 4.31 & 1.28 \\
\hline $\mathrm{Na}_{2} \mathrm{O}$ & 3.72 & 4.05 & 2.82 & 4.31 & 2.69 & 3.69 & 4.48 & 4.34 & 4.64 \\
\hline $\mathrm{K}_{2} \mathrm{O}$ & 1.80 & 2.26 & 3.28 & 2.54 & 0.51 & 0.63 & 0.80 & 0.58 & 1.31 \\
\hline $\mathrm{P}_{2} \mathrm{O}_{5}$ & 0.10 & 0.09 & 0.25 & & 0.13 & 0.11 & 0.08 & 0.19 & 0.04 \\
\hline \multicolumn{10}{|l|}{ Trace elements (ppm): } \\
\hline & 45 & 57 & & & & & 11 & 7.4 & 20 \\
\hline $\begin{array}{l}\mathrm{Sr} \\
\mathrm{Ba}\end{array}$ & 256 & 226 & & & & & 130 & $\begin{array}{l}183 \\
181\end{array}$ & 122 \\
\hline $\mathrm{Zr}$ & 109 & 128 & & & & & 142 & & 195 \\
\hline $\begin{array}{l}\mathrm{Nb} \\
\mathrm{Ce}\end{array}$ & $23^{3.6}$ & $27^{4.4}$ & & & & & & & \\
\hline $\mathrm{Nd}$ & & & & & & & $\begin{array}{l}14.4 \\
13.1\end{array}$ & 12.6 & \\
\hline $\begin{array}{l}\mathrm{Y} \\
\mathrm{Ni}\end{array}$ & 17 & 17 & & & & & 45 & & 48 \\
\hline $\mathrm{Sc}$ & 11 & 8 & & & & & & & \\
\hline $\begin{array}{l}V \\
\text { Pefemes }\end{array}$ & & & & & & & 26 & 26 & 14 \\
\hline Reference & (1) & (1) & (2) & (2) & (2) & (2) & (3) & (3) & (3) \\
\hline
\end{tabular}

Notes: "Higashi-Izu" is on the Izu Peninsula of Honshu; Miyojinsho (1952 eruption), Niijima, and Kozushima are islands. Results from the Aoga Rift and near Sumisu-jima were obtained from dredged samples. References: (1) Miyajima et al. (1985); (2) Kuna (1962); (3) Ikeda and Yuasa (1989),

$\mathrm{Si} / \mathrm{Al}$ ratio (cf. Dick and Bullen, 1984), and the correlation between Mg-numbers in coexisting olivines and spinels is the same as in MORB (Fig. 7B). However, the Cr-numbers of the spinels are lower than expected for the Mg-numbers of the spinels (Fig. 7A). This displacement from the pattern in MORB also characterizes some arc basalts and seems to reflect higher pressure fractionation than in MORB (Dick and Bullen, 1984; Luhr and Carmichael, 1985). $\mathrm{Fe}^{+3} / \Sigma \mathrm{Fe}$ ratios are higher than in $\mathrm{Cr}$-spinels from MORB, and increase from 0.35 to 0.62 as the $\mathrm{Mg} \#$ of the spinel phase decreases. In differentiated Sample 126-791B-53R-1, 10-12 cm, the spinel phase included in both olivine $\left(\mathrm{Fo}_{76}\right)$ and augite $\left(\mathrm{Wo}_{44} \mathrm{En}_{43} \mathrm{Fs}_{13}\right)$ phenocrysts has $\mathrm{Cr}_{2} \mathrm{O}_{3}=6 \mathrm{wt} \%$, whereas the magnetite in the groundmass has $\mathrm{Cr}_{2} \mathrm{O}_{3}=0.1 \mathrm{wt} \%$. Thus, the miscibility gap between spinel and magnetite is small in these slightly oxidized differentiates.

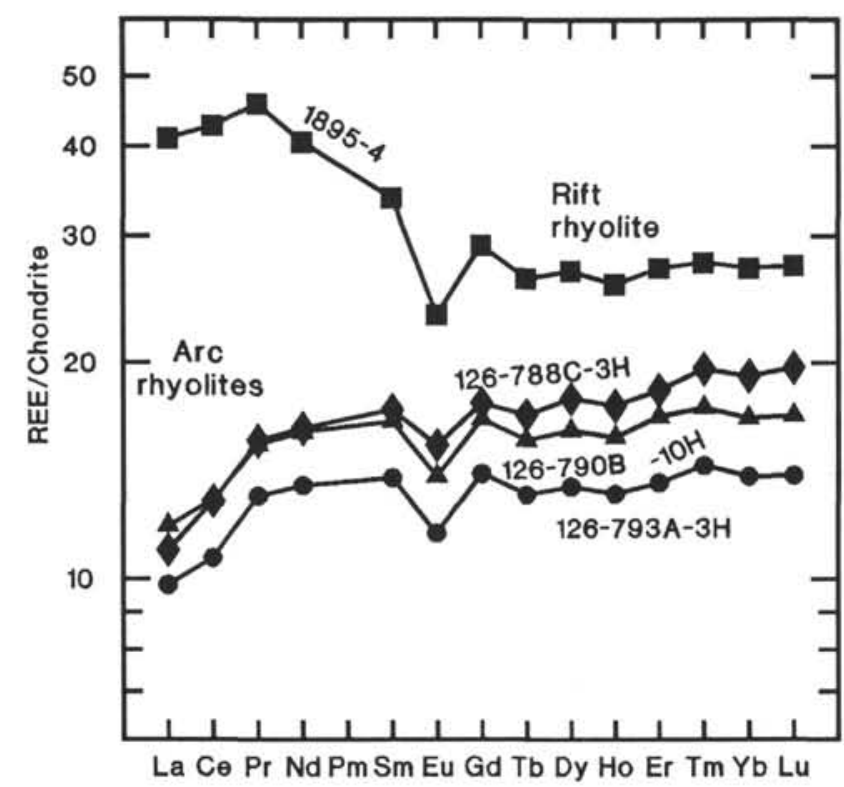

Figure 4. Chondrite-normalized REE patterns for post-rift-inception volcanic rocks. The "rift rhyolite" was collected using Alvin, and the "arc rhyolites" are from Leg 126.
Differentiation in the lavas is tholeiitic in character, characterized by Fe-Ti enrichment (Fig. 8). However, neither Fe nor Ti enrichment is as great with respect to $\mathrm{MgO}$ as in MORB, nor is the depletion in $\mathrm{Al}_{2} \mathrm{O}_{3}$. That the apparent lack of $\mathrm{Al}$-depletion is partly just a result of plagioclase accumulation is shown by the $3 \mathrm{wt} \%$ lower $\mathrm{Al}_{2} \mathrm{O}_{3}$ content of the mousse glass, discussed below. Incompatible elements, including $\mathrm{Zr}$ and $\mathrm{Y}$, increase by about $30 \%$ from the most to the least mafic lavas at both sites, implying about $20 \%$ fractional crystallization. Overall, the differentiation trend within the lavas is the same as within the younger SRB (Hochstaedter et al., 1990a).

Trace element characteristics and isotopic compositions also are similar to those of SRB (Figs. 9-11; cf. Hochstaedter et al., 1990b). The LREE are generally enriched in contrast to the LREE-depleted patterns of coeval samples from the arc (see above). The negative $\mathrm{Ce}$ anomalies

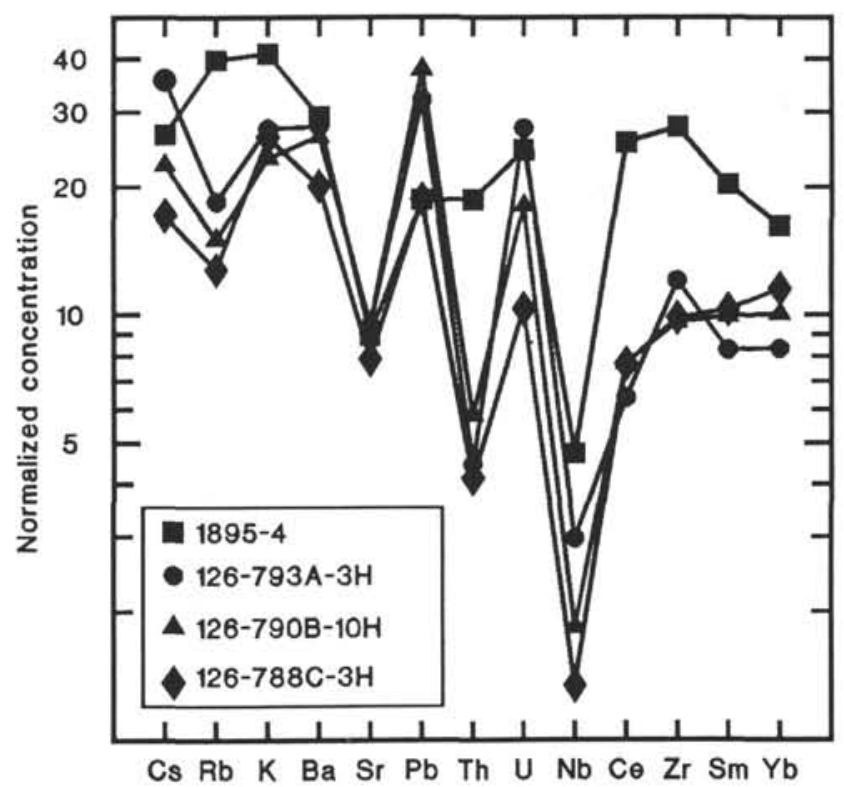

Figure 5. Normalized extended trace element diagram for post-rift-inception arc volcanic rocks; also see Figure 4. 
that are present in basalts at both Sites 790 and 791 are absent from the arc samples (Figs. 2 and 4), but probably are present in the younger Alvin-collected rift basalts for which La data were slightly suspect and not reported by Hochstaedter et al. (1990b). The ${ }^{87} \mathrm{Sr}{ }^{86} \mathrm{Sr}$ ratios of $0.70292-0.70302$ and ${ }^{143} \mathrm{Nd} /{ }^{144} \mathrm{Nd}$ ratios of $0.51307-0.51310$ are within the range of SRB, and the $\mathrm{Sr}$ ratios are distinctly lower than in the coeval arc samples (Fig. 11).

Trace elements are decoupled from each other between the sites. The 790 basement lavas have higher concentrations of $\mathrm{Zr}, \mathrm{Nb}$, and $\mathrm{Ba}$, greater enrichment of LREE, higher $\mathrm{Zr} / \mathrm{Y}$ ratios, and lower $\mathrm{Zr} / \mathrm{Nb}$ ratios than do most basement lavas at Site 791. Consequently, the lavas at Site 790 are more like E-MORB, whereas lavas at Site 791 are more like N-MORB. The more LREE-enriched basalts at Site 790 may have slightly higher $\mathrm{Sr}$ and lower $\mathrm{Nd}$ isotope ratios, but too few analyses were conducted for confidence.

In detail, the lavas from Site 791 are extremely Ba-poor (5-20 $\mathrm{ppm})$, poorer even than in SRB (30-50 ppm). This was suspected on the basis of shipboard XRF data, and has been confirmed by our subsequent XRF and ICP-MS results. Stunningly, therefore, even the earliest backarc basalts lack the characteristic $\mathrm{Ba}$ - spikes of island-arc basalts and are almost indistinguishable from MORB. At the other extreme, some ODP basalts, especially at Site 790, extend to higher concentrations of $\mathrm{Zr}$, LREE, $\mathrm{Sr}$, and $\mathrm{Na}$ than in SRB. The isotopic variation among the ODP lavas is less than between the inner ridges and Shadow Mountain types of SRB (Hochstaedter et al., 1990b), even though the trace element differences are greater. Percent melting, therefore, was more variable during the earliest arc rifting.

\section{The Mousse (Group 791-m)}

Igneous stratigraphic units 11,12 , and 14 constitute the second group cited above and form about half the basement drilled at Site 791. Collectively, these units are a 135-m-thick explosion breccia dubbed "mousse" at sea because of its dark, frothy appearance. This breccia is the earliest large syn-rift volcanic unit sampled from any backarc basin. It was described in detail by Gill et al. (1990), and its paleomagnetic characteristics and eruption style are discussed by Koyama et al. (this volume).

The mousse consists of three highly vesicular components: juvenile glass clasts; a fine-grained, glass-rich juvenile matrix; and accidental lithics. Their relative proportion has not been studied in detail, but it is approximately $5: 75: 20$. Both of the glassy juvenile components are thought to have quenched during explosive deep-water eruption, whereas the lithic materials are considered to be accidental. We analyzed 13 bulk samples by XRF (Table 7); glass and mineral analyses by microprobe are available for one of the freshest samples (Tables 7 and 9-13). Almost all the XRF analyses are of material that consists completely or mostly of the accidental clasts. Only Sample 126-791B-67R-1, 61-63 cm, is mostly matrix. This is because, at the time of shipboard sampling, the clasts seemed fresher and to be the only unambiguously igneous material. Obtaining hundreds of milligrams of fresh juvenile glass for analysis is difficult because small lithic clasts are ubiquitous.

The mousse is distinctive texturally because of its clastic nature and the vesicular, agglutinated character of its matrix. Lithic clasts are angular, monomict, variably vesicular basalt up to $6 \mathrm{~cm}$ in diameter (Fig. 12). (Rare clasts of indeterminant fine-grained material also occur.) Millimeter-sized lithic fragments are widespread and cannot be distinguished from the matrix without transmitted light, which reveals that the matrix within the lithic clasts is tachylite (opaque) formed by slower cooling, whereas the matrix surrounding the clasts is sideromelane (transparent) formed by rapid quenching (Fig. 13). (See Fisher and Schminke, 1984, for a discussion of submarine glass types.)

The juvenile glass clasts are up to $10 \mathrm{~mm}$ in diameter. Shards can be nonvesicular, or contain just a few vesicles, in regions up to $25 \mathrm{~mm}^{2}$ (see the cover photograph accompanying Gill et al., 1990; also see
Fig. 13). Most commonly, however, areas of dense glass occur between zones of intense vesiculation within which bubbles are closepacked ( $75 \%$ vesiculation; e.g., Fig. 14).

The matrix of the breccia is ubiquitously vesicular with a narrow size distribution of bubbles centered at $0.1 \mathrm{~mm}$ diameter. These vesicles are smaller and more uniform in size than in either the glass clasts or lithic clasts (Fig. 15). In reflected light, the matrix appears to consist of small vesicular glass shards, sometimes no larger than necessary to enclose a few 0.1 -mm-sized vesicles. There is a gradual transition between "glass clasts" and "matrix." Seen in transmitted light, vesicles are similarly deformed in some regions of sideromelane glass as large as $2 \mathrm{~mm}^{2}$, but they are differently deformed in other adjacent regions (Fig. 16). Microprobe analyses show that the glass clasts are homogeneous in composition. Consequently, the deposit is interpreted as consisting of a single juvenile component, with the matrix being thoroughly disrupted glass clasts. The volcanological implications of the texture of the mousse are discussed further by Gill et al. (1990) and Koyama et al. (this volume), who argue that it reflects a deep submarine Strombolian eruption.

The juvenile glass is differentiated basalt $(\mathrm{Mg \#}=50)$ broadly similar in composition to comparably differentiated overlying lavas (Table 7). The matrix contains euhedral olivine and plagioclase crystals, and the olivines contain spinel inclusions. Augite is absent from the mousse matrix although present in comparably differentiated lavas. The olivines are zoned from $\mathrm{Fo}_{85-80}$, the latter representing an equilibrium composition for the glass, assuming $\mathrm{K}_{\mathrm{D}}=0.30$ and molar $\mathrm{Fe}^{+3} / 2 \mathrm{Fe}=0.15$ (Fig. 6). This differs from the statement in Gill et al. (1990), that the olivines were too Fe-rich for equilibrium. Probe analyses of glass were not then available, and the discrepancy is a result of using the higher $\mathrm{Mg}$ \# of the matrix-rich Sample 126-791B$67 \mathrm{R}-1,61-63 \mathrm{~cm}$. The plagioclases and spinels range from $\mathrm{An}_{78-89}$ and $\mathrm{Cr} \#=35-38$, respectively, as in the overlying lavas (Table 9).

For the reasons cited above, more is known about the lithic clasts than about the juvenile component. The clasts have high Mg\# (6065 ), but lower $\mathrm{Ni}$ and $\mathrm{Cr}$ contents and higher $\mathrm{Sc}$ and $\mathrm{V}$ contents than most of the overlying lavas. $\mathrm{Zr}$ contents are similar with respect to $\mathrm{MgO}$, but low with respect to $\mathrm{Ni}$ when compared with the lavas, rendering the mousse clasts somewhat more like arc tholeiites than MORB. Little range in differentiation is indicated $(\mathrm{Ni}=40-60 \mathrm{ppm}$; $\mathrm{TiO}_{2}=1.0-1.1 \mathrm{wt} \%$ ).

Although petrographically the clasts appear monolithic, and the variation in compatible elements is small, significant variation exists in some trace elements. Broadly, two types of clast are present. The more common type has higher $\mathrm{P}_{2} \mathrm{O}_{5}(0.2-0.6 \mathrm{wt} \%)$ and $\mathrm{Y}(23-$ $42 \mathrm{ppm}$ ) than in SRB, whereas the other has concentrations similar to those in SRB (0.07-0.10 wt\% and $16-21 \mathrm{ppm}$, respectively). The high-P group also has higher $\mathrm{Sr}(200-250$ vs. $170-190 \mathrm{ppm})$ and $\mathrm{Ba}$ $(10-30$ vs. $5-6 \mathrm{ppm})$ but lower alkali contents. Based on this chemical contrast, the high-P group seems more altered, but this is not evident petrographically and no secondary phosphate minerals were observed. Before $\mathrm{HCl}$ leaching, the ${ }^{87} \mathrm{Sr} /{ }^{86} \mathrm{Sr}$ ratio in one high-P clast was 0.70370 (vs. 0.70330 in an unleached lava), whereas after leaching there was no difference between high- and low-P clasts (0.70303). Stable isotope studies showed that some clasts have been altered by seawater (Gill et al., 1990), but which type of clast is unknown.

Only one clast is exceptional. Sample 126-791B-73R-2, 84-86 cm, may be arc-derived, judging from its low $\mathrm{Ti}, \mathrm{Fe}$, and $\mathrm{Nb}$, and high $\mathrm{Si}$. It is also the only sample that has a secondary magnetic component (Koyama et al., this volume). Whether or not its geochemical distinctiveness reflects alteration could not be assessed petrographically because it had been thermally demagnetized first.

The differences between clasts and matrix are interpreted as indicating that the clasts were accidental (Gill et al., 1990). If, as in most pyroclastic basalt eruptions, the lithics are xenoliths entrained during ascent, then the clasts are samples of deeper stratigraphic levels than were drilled. The geochemistry of the clasts indicates that most 
Table 7. Major and trace element analyses of rift basement samples.

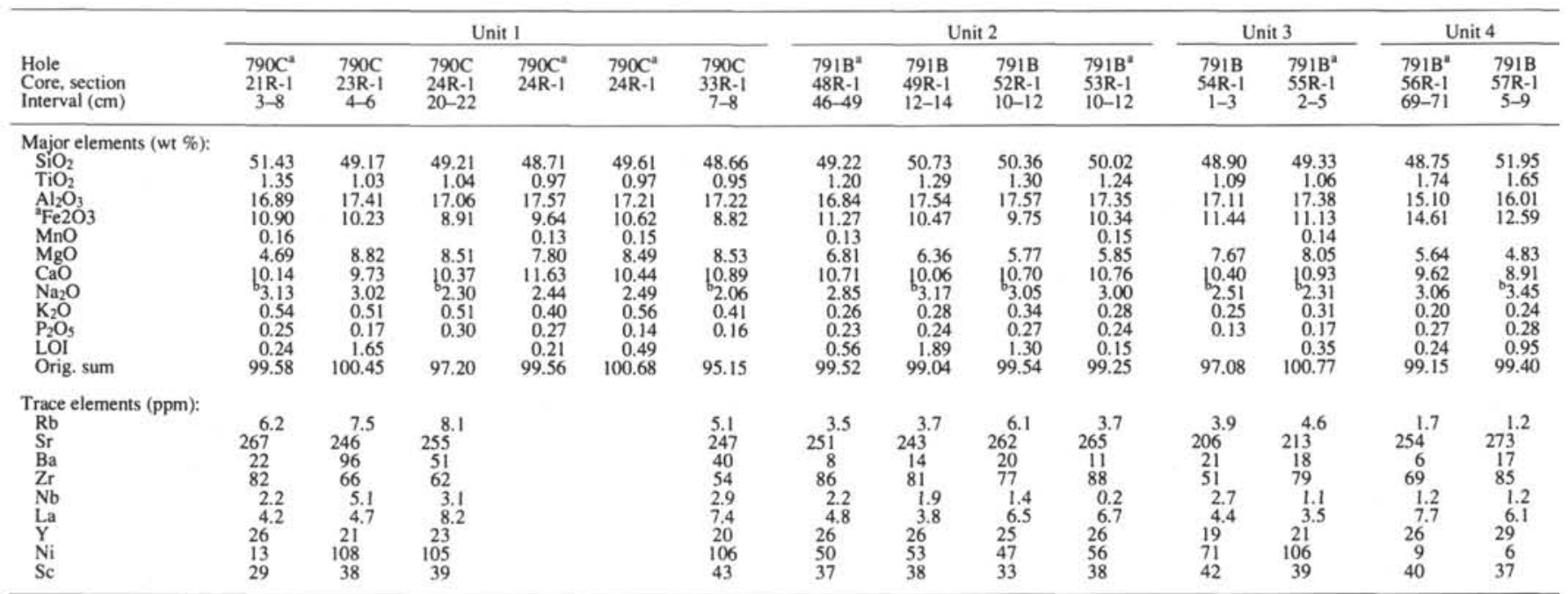

Note: $\mathrm{LOI}=$ loss of ignition

a Shipboard sample preparation and major element analyses.

Atomic absorptiion analysis.

arc geochemical characteristics were absent not only in the oldest major eruptive unit recovered from the rift, but also in what lies beneath Hole 791B.

Most of the discussion above refers to the top half of the mousse. Below Core 791B-67R, the rocks are more altered: olivines are replaced by calcite; smectite, zeolite, and native copper fill vesicles; and juvenile glass is predominantly smectite.

\section{The Dikes (Group 791-d)}

Five dike samples were analyzed. Units 8 and 17 span the same range in differentiation as the lavas. Dike Units 4 and 29 are the most differentiated material recovered and reflect a strong tholeiitic differentiation path, with $\mathrm{Fe}-\mathrm{Ti}$ enrichment and $\mathrm{Ca}-\mathrm{Al}$ depletion and little change in silica. Incompatible trace elements are not strongly enriched in these fine-grained samples, which suggests some late-stage loss of liquid from dike interstices but retention of oxides.

\section{The Oldest Samples (Group 791-b)}

Samples recovered from the base of Site 791, below the mousse, were quite altered. This is the depth interval in which the hole crosses seismically identified faults, where two different dikes intrude within $20 \mathrm{~m}$ of one another, and where hydrothermal alteration is greatest. Except for alteration, two of the samples (Units 24 and 27) are similar in composition and texture to the lavas of Group 791-t. Sample 126-791B-78R-1, 113-115 cm, is the oldest BABB encountered. It has similar trace element ratios but the lowest concentration of HREE of any sample analyzed (Table 4 and Fig. 13), which may be an analytical artifact (see "Sample Preparation and Analytical Methods" section, this chapter).

Units 20 and 28 are especially interesting because they differ from all the rest, both in texture and composition, and appear to be arc-derived. Compositionally, they have high $\mathrm{K}, \mathrm{Rb}$, and $\mathrm{Ba}$ contents, yet low HFSE contents. Although the high concentrations may just reflect alteration, samples immediately above and below are not similarly affected. Texturally, they are flattened lapilli tuffs showing plastically deformed and apparently welded fiamme. However, not all fiamme are parallel nor are all bubble walls flattened (Fig. 17). The uncollapsed matrix texture may reflect diagenetic alteration accompanying compaction and adjacent hydrothermal activity rather than pyroclas- tic flow (Allen, 1990). Consequently, although the samples probably were erupted in the arc, they may have been transported by cold debris flows rather than hot pyroclastic flows. As a result, they may have travelled a considerable distance before deposition in the rift. Although they are our only examples of arc volcanism during the 1-2 Ma interval, they need not represent pre-rift arc basement, a conclusion confirmed by the seismic stratigraphy, which suggests more rift fill below the base of Site 791 (Klaus et al., this volume).

The similarity in composition between pre-rift and rift basalt (see "Pre-rift Arc Volcanism" section, this chapter) leads to ambiguity in defining pre-rift basement in backarcs on the basis of petrology and geochemistry. The BABB lithic clasts in the mousse probably were derived from strata underlying Site 791. BABB compositions also characterize some lithic clasts (e.g., Sample 126-788C-15H-3, 68$71 \mathrm{~cm}$ ) and glass shards (Rodolfo et al., this volume) in the pre-rift Pliocene debris flows at Site 788 in the arc. Consequently, BABB was being erupted somewhere in the area before rifting began.

\section{SUMISU RIFT RHYOLITES}

Rhyolite lava caps the western and central en echelon ridges of the Sumisu Rift, about $20 \mathrm{~km}$ north of Site 791 (Taylor et al., 1990; Hochstaedter et al., 1990a). Although rhyolite has been dredged from the northern part of the western ridge, its distribution is unknown in detail. Consequently, this section focuses on the central ridge, which is entirely rhyolitic at depths shallower than $1900 \mathrm{~m}$ below sea level (mbsl). One rhyolite was dated at $276 \mathrm{ka}$ (Hochstaedter et al., 1990a).

Two types of rhyolite are present. One is dense, massive obsidian that is more differentiated, and the other is microvesicular, blocky, and slightly more mafic. The differences in composition are shown in Table 14 and are greater in compatible elements than in REE or HFSE. The more mafic rhyolites overlie the less mafic, as is common in subaerial pumice deposits, although uncommon in rhyolite domes (Carrigan and Eichelberger, 1990). The stratigraphy suggests sequential eruption of a zoned magma reservoir that was more differentiated at its top.

In stark contrast to the coeval arc samples, the Sumisu Rift Rhyolites (SRR) are entirely lava, never pumice. The SRR eruption site is $1500-1900 \mathrm{mbsl}$, whereas the floor of the closest arc caldera, Minami Sumisu Jima, is $800-850 \mathrm{mbsl}$ and is covered by rhyolite pumice (Taylor et al., 1990). Although the additional 100 bar pressure 
Table 7 (continued).

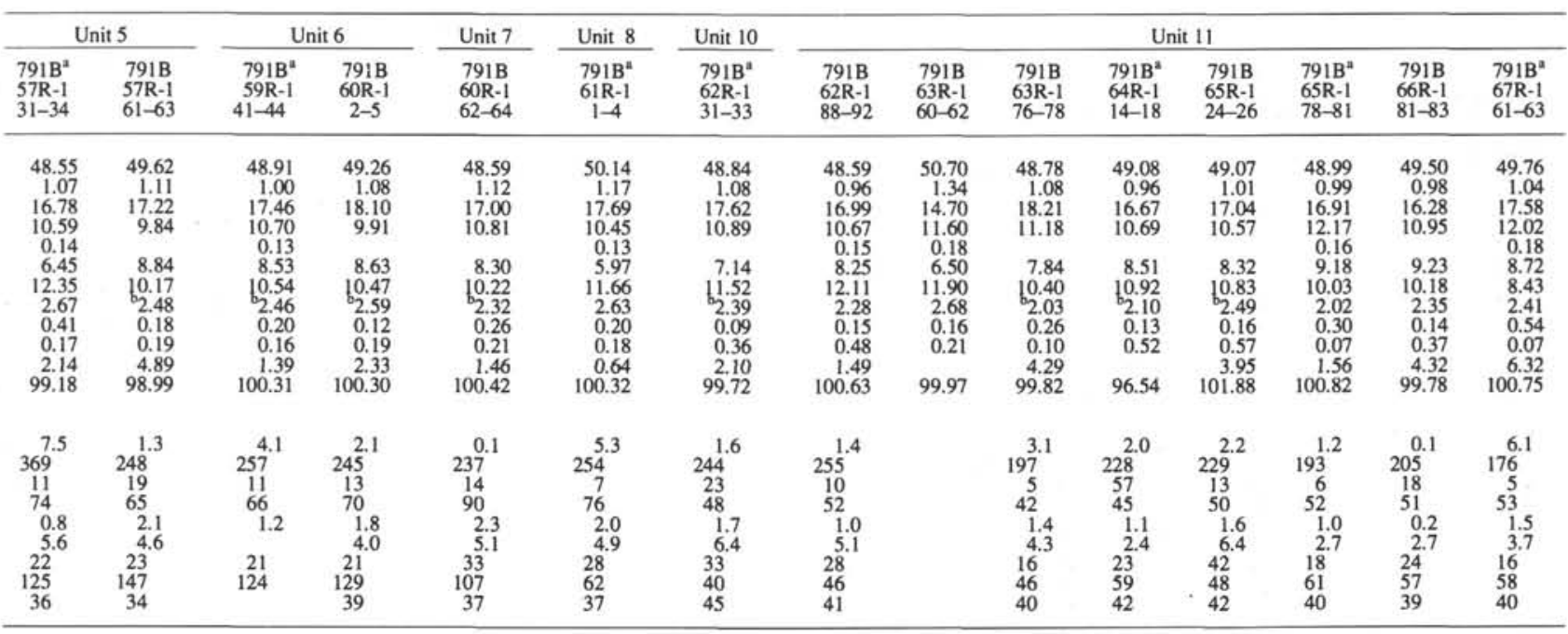

on the rift seafloor might be sufficient to suppress vesiculation in comparably hydrous rhyolite magma, the pressure difference is so slight that SRR probably are drier magma. This greater dryness is even more remarkable because the SRR are also more differentiated.

Eight rhyolite samples from two Alvin dives were studied (Tables 3,4 , and 10). All except one are low-K R3 rhyolites; the exception is a medium-K rhyolite from the upper, more mafic group. Although $\mathrm{SiO}_{2}$ contents are similar to those of arc rhyolites on an anhydrous basis, SRR have lower compatible element concentrations than in any Pleistocene arc pumices.

Furthermore, rift rhyolites differ from arc rhyolites in all the same ways that rift basalts differ from arc basalts and andesites (Hochstaedter et al., 1990a, 1990b). That is, SRR have light-enriched REE patterns, no Ba spike (the difference is in LREE rather than $\mathrm{Ba}$ concentration), and higher $\mathrm{Th}, \mathrm{U}, \mathrm{Zr}, \mathrm{Hf}, \mathrm{Nb}$, and $\mathrm{Be}$ contents (as well as LREE) relative to HREE (Figs. 4 and 5). Also, they have significantly lower ${ }^{87} \mathrm{Sr} /{ }^{86} \mathrm{Sr}$ and slightly lower ${ }^{143} \mathrm{Nd} /{ }^{144} \mathrm{Nd}$ ratios than do coeval arc rhyolites. The significance of differences in the higher absolute concentrations of incompatible trace elements is ambiguous because the SRR are more differentiated overall.

\section{MAGMA SOURCES DURING BACKARC BASIN INCEPTION}

The principal change in composition of magma during the history of the Izu arc-backarc system occurred during the early Oligocene when REE patterns changed from flat to LREE-depleted, perhaps in association with the establishment of a volcanic arc about as far from the plate boundary as the volcanic front is now (Hiscott and Gill, this volume). Within this context, the changes during the most recent episode of arc rifting are less dramatic, but they can be placed within a better understood context of time and tectonics. There is, nonetheless, ambiguity about "when rifting began"; the following adopts $2 \mathrm{Ma}$ as the time (after B. Taylor, this volume).

One surprising result of this study is that backarc basin basalt (BABB) and related rhyolite were present before rift formation. However, this leaves open the question whether the BABB source was always present (in which case tapping the $\mathrm{BABB}$ source was a passive result of extension), or was recently intruded (so that extension was the result of intrusion); see Hochstaedter et al. (1990b) for discussion.
Another surprise is that the "island arc geochemical signature" was more evident after than before the inception of arc rifting; that is, the recycled slab component (rich in $\mathrm{Cs}, \mathrm{U}, \mathrm{Pb}, \mathrm{Ba}$, and ${ }^{87} \mathrm{Sr}$ ) has increased in the arc during the early stages of formation of the backarc basin. If the Pliocene volcanic front was on what is now the NishiShichito Ridge, then this increase accompanied trenchward migration of the volcanic front after the inception of rifting, perhaps as the result of tapping fertilized mantle that previously underlay the forearc (Stern et al., 1988). Alternatively, if the volcanic front has remained fixed with respect to the trench (see the "Pre-rift Arc Volcanism" section, this chapter), then the increase may reflect either the cumulative effects of slab dehydration or a greater focusing of slab derivatives relative to the percent of melting beneath the volcanic front during the inception of rifting.

A third surprise is that the magma eruption rate in the arc increased during incipient rifting, primarily in the form of explosive silicic volcanism. Furthermore, although volcanism in both the arc and incipient rift is compositionally bimodal, neither of the silicic modes seems to be crustally derived. Were the rhyolites the product of crustal anatexis, the simplest interpretation of the increased eruption rate and bimodality would attribute the basalt to partial melting of the mantle, attribute the rhyolite to partial melting of mafic crust caused by intrusion of the basalt, and attribute the overall increase in magma production rate to decompression of the mantle accompanying rifting.

However, there are three arguments against crustal derivation of the rhyolites. First, the arc and rift rhyolites consistently differ in trace element and isotopic characteristics. Those from the arc are LREEdepleted, have typical arc relative enrichments in $\mathrm{Cs}, \mathrm{U}, \mathrm{Pb}, \mathrm{Ba}$, and ${ }^{87} \mathrm{Sr}$, and greater relative depletions in HFSE. The greater explosivity of arc rhyolite may also indicate higher water contents. Although two exceptional rift-like rhyolite pumice clasts were found in pre-rift debris flows at Site 788 , the overall volcaniclastic sediments are similar in composition to arc rhyolites and dissimilar to rift ones (Hiscott and Gill, this volume). There is no reason to expect such striking geographic segregation among crustally derived melts because there is no reason to expect crustal heterogeneities of this type and distribution. The second and related argument against crustal anatexis is that the differences between rift and arc rhyolites are the same as the differences between rift and arc basalts. The rift rhyolites are identical in $\mathrm{Sr}-\mathrm{Nd}$ isotopes and similar in trace element enrichment 
Table 7 (continued).

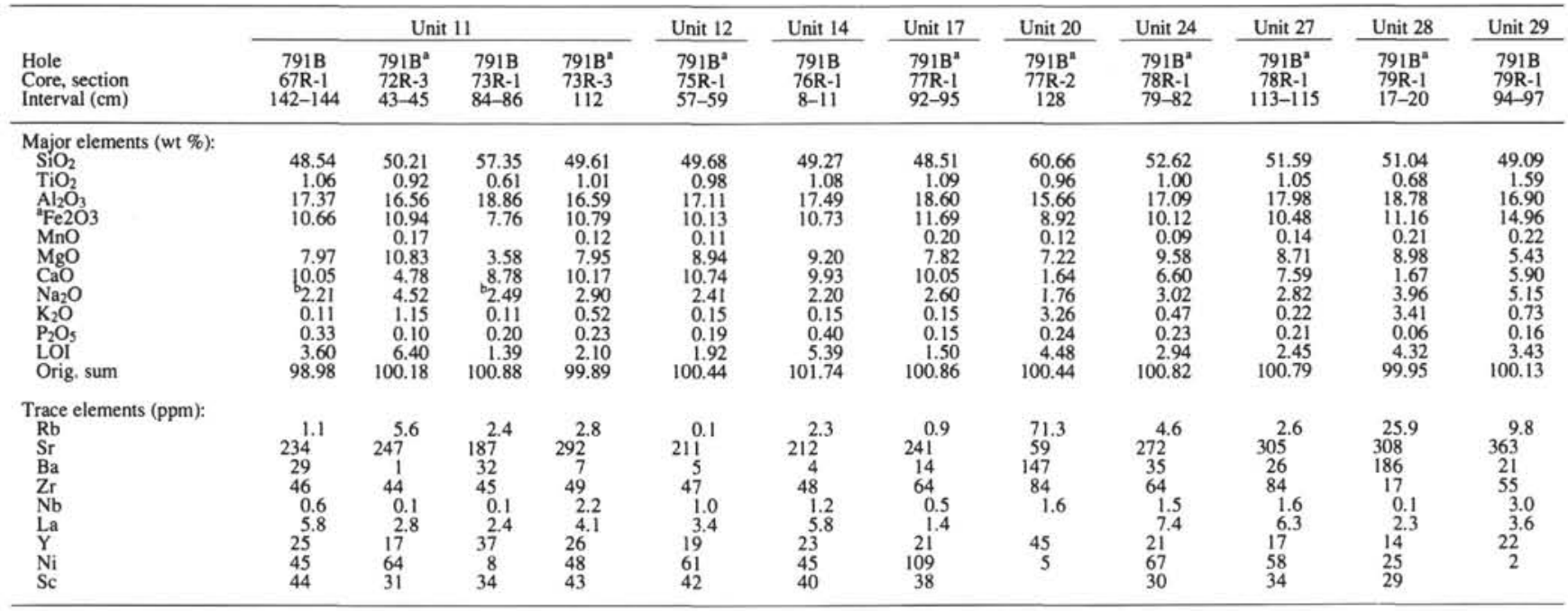

pattern to rift basalts, as are the arc rhyolites similar to arc basalts and andesites. Although the range in differentiation and the space-time variability preclude meaningful quantitative tests of consanguinity for either rift or arc basalt-rhyolite suites, nothing in our data qualitatively precludes either silicic mode from being derived from their associated basalts by fractional crystallization. The final argument is that internal variations within the Pleistocene pumices of the forearc at Site 793, which range from 63 to $73 \mathrm{wt} \% \mathrm{SiO}_{2}$, are more explicable in terms of fractional crystallization than partial melting. That is, with the exception of one anomalous mixture of pumice clasts from Section 126-793A-3H-6, compatible element concentrations (e.g., Sc, Ti, Mg) drop by a factor of 2 whereas alteration-resistant incompatible element concentrations (e.g., Zr, Y) increase by $<40 \%$. Although this does not preclude the dacite from being a primary anatectic melt, variation within the silicic mode is a result of fractional crystallization. Because all the rhyolites of both suites are low-K, the mafic parent must have had very low $\mathrm{K}_{2} \mathrm{O}$, and differentiation must have involved rapid increase in $\mathrm{SiO}_{2}$ as the result of crystallizing calcic plagioclase and magnetite.

The preceding paragraph implicitly assumed that "rift rhyolites" do not erupt at the volcanic front. Possible evidence against this assumption was noted earlier (see "Post-rift-inception Arc Volcanism" section, this chapter), and the distinction could be gradational, both geochemically and geographically. Although indiscriminant intermingling of backarc and arc basalts along the volcanic front would affect geodynamical models of the mantle wedge, the eruption of "rift rhyolites" at the volcanic front would not undercut the three conclusions reached above.

Within the backarc, another surprising observation is that the earliest Sumisu Rift volcanism is even less arc-like than the previously studied surface samples (SRB). Apart from high $\mathrm{H}_{2} \mathrm{O}$ and $\mathrm{U}$ contents relative to other incompatible elements, and negative $\mathrm{Ce}, \mathrm{Nb}$, and $\mathrm{Zr}$ spikes relative to REE, there is little to distinguish any basalts in the Sumisu Rift from E-MORB. The ODP samples appear similar in mineral compositions and differentiation style, and therefore in water pressure and oxygen fugacity, to SRB. However, the earliest basalts at Site 791 formed exotic explosive pyroclastic deposits $>1800 \mathrm{mbsl}$, as a result in part of their high water contents (Gill et al., 1990; Koyama et al., this volume). Despite this, alkali and alkaline earth concentrations are even lower in basaltic rocks from Site 791 than in SRB. Hence, the striking geochemical contrast between arc and backarc magmas was present during the earliest phase of rift development.

In addition to eruption style and alkaline earth concentrations, which are subduction-related parameters, the ODP samples provide somewhat more extreme examples of E-MORB than do the Alvin-collected suite. The LREE and HFSE enrichment is greater in the basalts of Site 790 than in those of Shadow Mountain on the seafloor, although $\varepsilon_{\mathrm{Nd}}$ in the ODP samples is not as low.

As with the surface samples, a key issue is whether the apparent differences between more and less depleted samples has the same explanation as between N-MORB and E-MORB, or whether it is a result of recent subduction-related metasomatism (cf. Hochstaedter et al., 1990b, with Fryer et al., 1990). Because the more E-MORB-like character of Site 790 basalts is accompanied by higher $\mathrm{Zr}, \mathrm{Nb}$, and LREE, we continue to think that the contrasts reflect differences in addition to those attributable to recent subduction. The basalts from Site 790 are from a more enriched, more OIB-like, source.

\section{COMPARISON WITH THE LAU BASIN}

Comparable information about magma compositions before, during, and after incipient rifting is known for the Lau Basin (Gill, 1976a; Cole et al., 1985, 1990; Hawkins and Melchior, 1985; Gill and Whelan, 1989a, 1989b). There, rifting apparently began at about $5 \mathrm{Ma}$ and spreading began at about $3 \mathrm{Ma}^{3}$ The spreading center is now a southward-propagating axial rift in the northern Lau Basin, and a ridge close behind the arc volcanoes in the southern Lau Basin (Parson et al., 1990).

Although similar, the sources of data for the two arc-backarc pairs differ in two respects. For the Sumisu case, our results for pre- and syn-rift arc rocks are drawn entirely from the trenchward side of the backarc basin, and we know that our backarc basalts were erupted within the rift during the first million years of its existence. In contrast, in the Lau case, the samples of pre-rift arc rocks are from the remnant arc, the samples of syn-rift arc rocks are initially from the remnant arc

${ }^{3}$ Copies of the "Leg 135 Preliminary Report, Lau Basin" are available from Science Operations, Ocean DrillingProgram, 1000 Discovery Drive, College Station, TX 77845 9547, U.S.A. 
Table 8. Modal phenocryst mineralogy of rift basement samples.

\begin{tabular}{|c|c|c|c|c|c|c|}
\hline $\begin{array}{l}\text { Core, } \\
\text { section }\end{array}$ & Piece & Unit & Olivine & $\begin{array}{l}\text { Plagio- } \\
\text { clase }\end{array}$ & $\begin{array}{c}\text { Clino- } \\
\text { pyroxene }\end{array}$ & $\begin{array}{l}\text { Mag- } \\
\text { netite }\end{array}$ \\
\hline \multicolumn{7}{|l|}{$\begin{array}{r}126-790 \mathrm{C}- \\
21 \mathrm{X}-\mathrm{CC}\end{array}$} \\
\hline & 2 & 1 & $<$ & $\mathrm{x}$ & - & - \\
\hline \multicolumn{7}{|l|}{$126-791 \mathrm{~B}-$} \\
\hline $47 \mathrm{R}-1$ & 3 & 1 & $<$ & $<$ & $\bar{v}$ & $N$ \\
\hline $47 \mathrm{R}-1$ & 10 & i & $<$ & $<$ & $\mathrm{X}$ & $\mathrm{N}$ \\
\hline $47 \mathrm{R}-1$ & 11 & 1 & $<$ & $<$ & - & $<$ \\
\hline $47 \mathrm{R}-1$ & 17 & i & (<) & $<$ & - & $\mathrm{N}$ \\
\hline $48 \mathrm{R}-1$ & 9 & 2 & $<$ & $<$ & $<$ & $<$ \\
\hline $53 \mathrm{R}-1$ & 5 & 2 & $\mathrm{x}$ & $<$ & $<$ & $<$ \\
\hline $55 \mathrm{R}-1$ & 1 & 3 & $<$ & $x$ & - & $N$ \\
\hline $56 R-1$ & i & 3 & (<) & $\hat{x}$ & - & $N$ \\
\hline $56 \mathrm{R}-1$ & 2 & 3 & $<$ & $\underset{\mathrm{X}}{\mathrm{X}}$ & $\bar{x}$ & $\mathrm{~N}$ \\
\hline $56 R-1$ & 13 & 4 & $<$ & $\underset{\mathrm{x}}{\mathrm{X}}$ & $\underset{v}{X}$ & $<$ \\
\hline $57 \mathrm{R}-1$ & 1B & 4 & $(<)$ & $\underset{x}{x}$ & $\mathrm{X}$ & $\leq$ \\
\hline $57 \mathrm{R}-1$ & 4 & 5 & $\mathrm{X}$ & $\underset{\mathrm{y}}{\mathrm{X}}$ & - & $\mathrm{N}$ \\
\hline $57 \mathrm{R}-1$ & 8 & 5 & (<) & $\mathrm{X}$ & - & $\leq$ \\
\hline $59 \mathrm{R}-1$ & 5 & 6 & $<$ & $<$ & - & $\mathrm{N}$ \\
\hline 60R-1 & 1 & 6 & $<$ & $<$ & - & - \\
\hline $60 R-1$ & 13 & 7 & $<$ & $<$ & - & - \\
\hline 61R-1 & 1 & 8 & - & $\mathrm{X}$ & - & $\mathrm{N}$ \\
\hline $62 R-1$ & $1 \mathrm{~A}$ & 10 & (<) & $<$ & - & $\bar{x}$ \\
\hline $62 \mathrm{R}-1$ & 1B & 10 & - & $\mathrm{X}$ & - & $\mathbf{N}$ \\
\hline $62 R-1$ & 5B & 11 & - & $\mathrm{X}$ & - & N \\
\hline $63 \mathrm{R}-1$ & 10B & 11 & (<) & $\mathrm{x}$ & - & $\overline{-1}$ \\
\hline $63 \mathrm{R}-1$ & 13B & 11 & $<$ & $<$ & - & $\mathrm{N}$ \\
\hline $64 \mathrm{R}-1$ & 13 & 11 & (<) & $<$ & $<$ & $\mathrm{N}$ \\
\hline $64 \mathrm{R}-2$ & 1 & ii & $<$ & $\mathrm{x}$ & - & $\mathrm{N}$ \\
\hline $65 \mathrm{R}-1$ & 5 & 11 & (<) & $<$ & - & - \\
\hline $65 \mathrm{R}-1$ & 17 & 11 & (<) & $\mathrm{x}$ & - & $\mathrm{N}$ \\
\hline $66 \mathrm{R}-1$ & 15 & ii & (<) & $<$ & - & - \\
\hline $67 \mathrm{R}-1$ & 5 & ii & (<) & $<$ & - & - \\
\hline $67 \mathrm{R}-1$ & 10 & 11 & - & $<$ & - & - \\
\hline $67 \mathrm{R}-1$ & 9 & ii & (<) & $<$ & - & $\mathrm{N}$ \\
\hline $68 \mathrm{R}-1$ & 9 & ii & (<) & $<$ & - & $\mathrm{N}$ \\
\hline $70 R-1$ & 10 & 11 & - & $<$ & - & $\mathrm{N}$ \\
\hline $70 \mathrm{R}-1$ & 12 & II & (<) & $<$ & - & - \\
\hline $72 \mathrm{R}-11$ & 18 & 11 & (<) & $<$ & - & - \\
\hline $72 \mathrm{R}-3$ & $2 \mathrm{~A}$ & ii & (<) & $<$ & - & $N$ \\
\hline $73 R-3$ & 10 & ii & (<) & $\mathrm{x}$ & - & $\mathrm{N}$ \\
\hline $75 \mathrm{R}-1$ & 10 & 12 & (<) & $\mathrm{x}$ & - & $\mathrm{N}$ \\
\hline $76 \mathrm{R}-1$ & 1. & 14 & (<) & 3 & - & N \\
\hline $76 R-2$ & $6 \mathrm{~F}$ & 14 & (<) & $\mathrm{x}$ & - & $\mathrm{N}$ \\
\hline $76 \mathrm{R}-3$ & $4 \mathrm{~A}$ & 15 & (<) & $\mathrm{x}$ & $x$ & $<$ \\
\hline $77 \mathrm{R}-1$ & 1 & 16 & - & $\mathrm{x}$ & $\bar{v}$ & $\mathrm{~N}$ \\
\hline $77 \mathrm{R}$ & 7 & 17 & (<) & $\mathrm{x}$ & $\mathrm{X}$ & $<$ \\
\hline 77 & $2 \mathrm{~A}$ & 19 & & $\leq$ & $<$ & $<$ \\
\hline $77 R-2$ & $6 \mathrm{~A}$ & 20 & - & $x$ & - & $<$ \\
\hline $77 R-3$ & $1 \mathrm{~A}$ & 20 & - & $\underset{\mathrm{X}}{\mathrm{X}}$ & - & $<$ \\
\hline $78 \mathrm{~B}$ & 2 & 22 & $\overline{x_{0}}$ & $\underset{\mathrm{X}}{\mathrm{X}}$ & $\bar{x}$ & $<$ \\
\hline 78R-1 & 3B & 23 & (X) & $\mathrm{X}$ & $\mathrm{X}_{\mathrm{N}}$ & $<$ \\
\hline $78 \mathrm{R}-1$ & 8 & $\begin{array}{l}24 \\
26\end{array}$ & (X) & $\bar{x}$ & $\begin{array}{l}\text { N } \\
X\end{array}$ & \\
\hline $\begin{array}{l}78 R-1 \\
78 R-1\end{array}$ & $\begin{array}{l}10 \mathrm{~A} \\
12 \mathrm{~A}\end{array}$ & $\begin{array}{l}26 \\
27\end{array}$ & - & $(\hat{\mathrm{X}})$ & $\hat{<}$ & $\mathrm{N}$ \\
\hline $79 R-1$ & 3 & 28 & - & $\mathrm{X}_{\mathrm{X}}^{\mathrm{X}}$ & - & $\mathrm{N}$ \\
\hline $79 \mathrm{R}-1$ & 6 & 28 & $\bar{x}$ & $X_{X}$ & - & $N$ \\
\hline $79 \mathrm{R}-1$ & 7 & 29 & $(\mathrm{X})$ & (X) & (X) & $\mathrm{N}$ \\
\hline
\end{tabular}

Notes: Phenocrysts are $>0.5 \mathrm{~mm}$ except for magnetite where $>0.1 \mathrm{~mm} . \mathrm{X}$ indicates $>5 \%$ by volume; $<$ indicates $1 \%-5 \% ;-$ indicates not present. $\mathbf{N}$ indicates that the silicate phenocrysts were tabulated in Sites 790/791, table 11 of Taylor, Fujioka, et al. (1990), but the thin sections were unavailable for further study. Parentheses indicate some alteration. Units are the shipboard igneous stratigraphic units (Taylor. Fujioka, et al., 1990).

and later from the volcanic arc, and the age and tectonic context of the oldest backarc basin basalts (Leg 135, Site 834) are more speculative.

In the Lau case, arc volcanism immediately before rifting constitutes the "mature arc stage" of Fiji (Gill, 1987). Closest to the eventual Lau Basin, these volcanic rocks form the Lau Volcanic Group (LVG). At the volcanic front, they consist mostly of medium-K tholeiitic andesites characterized by slight LREE-enrichment, high $\varepsilon_{\mathrm{Nd}}(+8.0-8.4)$, low ${ }^{87} \mathrm{Sr} /{ }^{86} \mathrm{Sr}(0.7027-0.7034)$, and low $\mathrm{Sr} / \mathrm{Zr}$ ratios (Gill, 1976a, 1987; Cole et al., 1985, 1990). In both cases, pre-rift arc volcanism is more enriched in LREE, $\mathrm{Zr}$, and $\mathrm{Th}$, but more depleted in $\mathrm{Ba}, \mathrm{Sr}, \mathrm{Pb}$, and $\mathrm{U}$ than is arc volcanism, which postdates rift inception.

The oldest basalts in the backarc basin are MORB-like in both cases. In the Sumisu Rift, this is the "mousse" at Site 791; in the Lau Basin, it is the basement at Site 834 (see footnote 3). In the Lau case, an isotopically enriched component is present in the northern basin
(Volpe et al., 1988); this component appeared in the remnant arc when the spreading stage of backarc basin formation began (Gill and Whelan, 1989b; Cole et al., 1990). The enriched component is more subtle in the Sumisu case, but concentrations of HFSE and LREE are higher in the initial backarc than in pre- or syn-rift arc lavas.

In the Lau case, rifting began in the forearc and syn-rift arc volcanism continued on the proto-remnant arc (the Lau islands), where it is preserved as the Korobasaga Volcanic Group (KVG; Gill, 1976a; Cole et al., 1985, 1990; Gill and Whelan, 1989a). The KVG is characterized by high relative enrichments of alkalis, alkaline earths (including ${ }^{87} \mathrm{Sr}$ ), and $\mathrm{U}$, implying a large slab component. It also is characterized by flat REE, low concentrations of HFSE and Th, and high $\varepsilon_{\mathrm{Nd}}$ and $\varepsilon_{\mathrm{Hf}}$ of about +8.4 and +15.4 , respectively (also see Salters and Hart, 1991), implying a depleted source apart from the recent slab component. Much less is known about the Sumisu case, but volcanism also appears to continue on the proto-remnant arc; although one dacite cap is known, Ba enrichment is absent (Fryer et al., 1990).

In summary, pre-rift arc magmas in both cases had relatively small amounts of slab-derived components. In both cases, the rifting stage was characterized by the immediate tapping of a MORB-type source with even less slab-derived material (mostly water). A source characterized by an older enrichment appeared during the spreading stage in the Lau case, at the free northem end of the basin. In the Sumisu case, an older enrichment is present even during the rifting stage. In both, syn-rift volcanism continues on the remnant arc; this is clearly arc volcanism in the Lau case, but not in the Sumisu. In both, subsequent frontal arc volcanism that accompanies rifting or spreading is especially enriched in components apparently derived from the slab.

\section{CONCLUSIONS}

Starting about 2 m.y. before rifting began in the Pliocene, and continuing afterward, frontal arc volcanism in the Izu Arc became primarily dacitic to rhyolitic in composition. This reflects development of large submarine calderas, seven of which now exist in the arc (Murakami and Ishihara, 1985). Because the silicic magmas appear to be differentiates of subcrustal basalt rather than crustally derived, this upsurge in silicic volcanism is attributed to changes in stress within the arc that permitted eruption of highly viscous magma as a more tensional regime developed. Judging from the record at Sites 790 and 791, the rate of this transition in the vicinity of the Sumisu Rift accelerated rapidly at about $130 \mathrm{ka}$, since which time large-volume rhyolite eruptions have been common. This increase in eruption rate apparently differs from the situation in the Izu Arc during rifting in the Oligocene, when arc volcanism reached a minimum during spreading within the Shikoku Basin (B. Taylor, this volume). The difference may, however, merely reflect greater time resolution in the more recent case; that is, the late Quaternary spurt may be a last gasp.

This is the first andesite-to-rhyolite transition to be well-documented, both geodynamically and geochemically, in an oceanic arc. In continental environments, such transitions have been interpreted as reflecting a reduction in magma supply rate associated with the cessation of subduction (e.g., Wark et al., 1990). The petrological evidence and interpretations are similar in both realms; the differences in geodynamic context, in magma supply vs. eruption rate, and in the effects of stress on magma transport and storage where crust is thick vs. thin await further study.

During the $2 \mathrm{~m} . \mathrm{y}$. before rifting, juvenile magmas continued to be LREE-depleted, but there was a diminution in the amount of upper crustal components (as estimated by $\mathrm{Ba} / \mathrm{La}, \mathrm{Sr} / \mathrm{Nd}$, and $\mathrm{Cs} / \mathrm{Rb}$ ratios) in these magmas. The Pleistocene rhyolites are more arc-like than were their Pliocene counterparts.

As noted previously, there is a striking contrast between magmas erupted within the Sumisu Rift and those from the adjacent arc (Ikeda and Yuasa, 1989; Fryer et al., 1990; Hochstaedter et al., 1990a, 1990b). The differences between rift and arc magmas have been interpreted as indicating the presence of a source beneath the rift that 


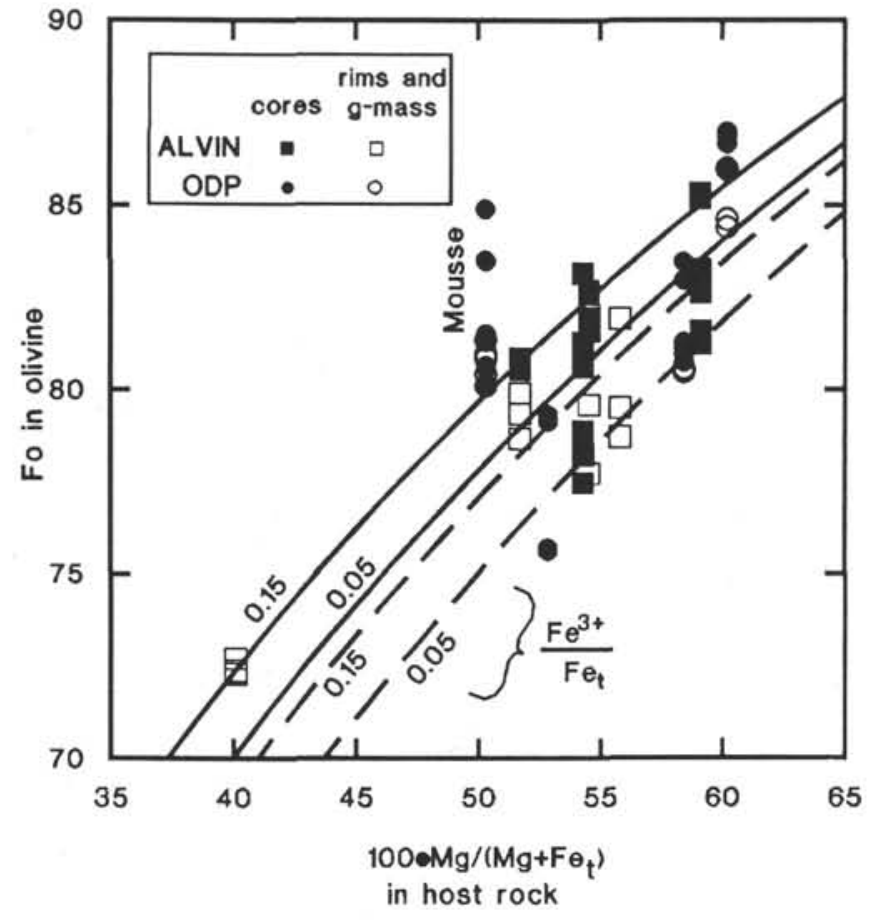

Figure 6. The composition of olivine phenocrysts in Sumisu Rift basalts (SRB). Circles are ODP samples, and squares are for Alvin-collected basalts (Hochstaedter et al., 1990a). Closed symbols are cores; open symbols are rims and groundmass. The solid lines show equilibrium compositions, assuming $\mathrm{K}_{\mathrm{D}}=0.30$ (Roedder and Emslie, 1970) and molar $\mathrm{Fe}^{+3} /\left(\mathrm{Fe}^{+2}+\mathrm{Fe}^{+3}\right)=0.05$ and 0.15 , as shown. Measured Fe oxidation states lie within this range (Hochstaedter et al., 1990a). The dashed lines assume $\mathrm{R}_{\mathrm{D}}=0.35$.

differs not only in lacking as much slab-derived component, but also in having greater "old enrichment"; that is, reflecting more of an E-MORB source in the rift vs. an N-MORB source in the arc (Ikeda and Yuasa, 1989; Hochstaedter et al., 1990b). Our results generally confirm this suggestion. However, even though LREE, $\mathrm{Zr}$, and $\mathrm{Nb}$ contents are especially high in basalts from Site 790 , their $\varepsilon_{\mathrm{Nd}}$ ratios are not as low as the lowest ratios of SRB. Also, we show that the rift basalts have clear negative $\mathrm{Ce}$ anomalies, just as do the early Sea of Japan basalts (Cousens et al., 1990). Thus, the earliest basalts erupted in the rift had the same Nd isotopic composition as the arc magmas as well as some subduction-related characteristics, including high water contents and negative $\mathrm{Ce}$ and $\mathrm{Nb}$ anomalies. However, they lacked other subduction-related traits such as ${ }^{87} \mathrm{Sr} /{ }^{86} \mathrm{Sr}$ ratios to the right of the mantle array, positive Ba spikes, and high $8^{34} \mathrm{~S}$ (Gill et al., 1990). This is a much more rapid transition from arc to backarc magma types, in time as well as space, than had been imagined. Despite the apparently high water content and high eruption rate of the oldest rift basalts (the mousse), they are more MORB-like in trace element and isotopic composition than are the modern Mariana Trough basalts, for example (Hawkins and Melchior, 1985).

Mineral compositions are similar in the early (ODP) and later (Alvin) rift basalts. Plagioclase and spinel compositions confirm earlier suggestions of higher water pressure and somewhat higher $\mathrm{fO}_{2}$ than in MORB. Differences from MORB in the correlation between $\mathrm{Mg} \#$ and $\mathrm{Cr} \#$ in the spinels may reflect higher pressure fractionation because of the thicker crust during incipient rifting.

Individual pumice clasts, but not bulk volcaniclastic sediments, show that rift-type basalts and rhyolites were present before rifting began. If, as argued above, some of the differences in composition are the result of a different source, then either a new E-MORB source intruded before a morphological rift developed, or E-MORB compo-
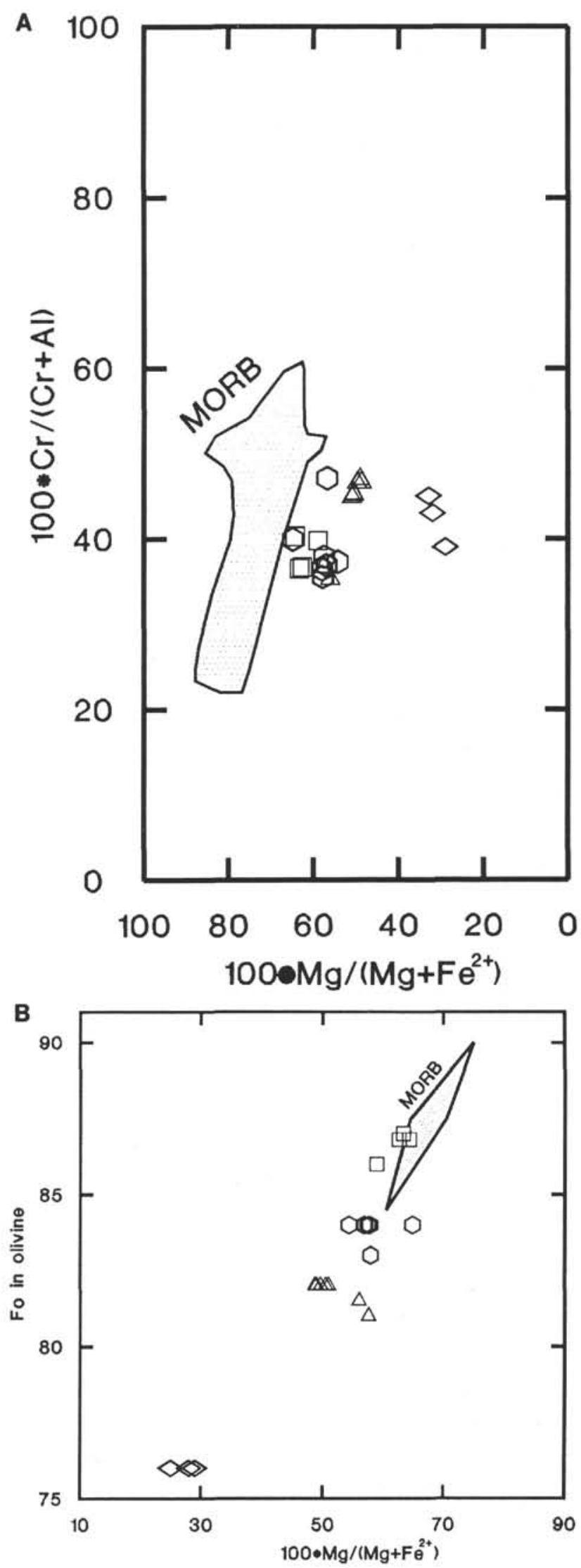

Figure 7. A. The composition of spinel inclusions in olivines in Sumisu Rift basalts (SRB). The symbols denote the host olivine compositions: square, $>\mathrm{Fo}_{85}$; hexagon, $\mathrm{Fo}_{84}$; triangle, $\mathrm{Fo}_{81-82}$; diamond, $\mathrm{Fo}_{76}$. The field for MORB is from Dick and Bullen (1984). B. Mg\# of spinels and their host olivines in Sumisu Rift basalts. Symbols as in Figure 7A. 

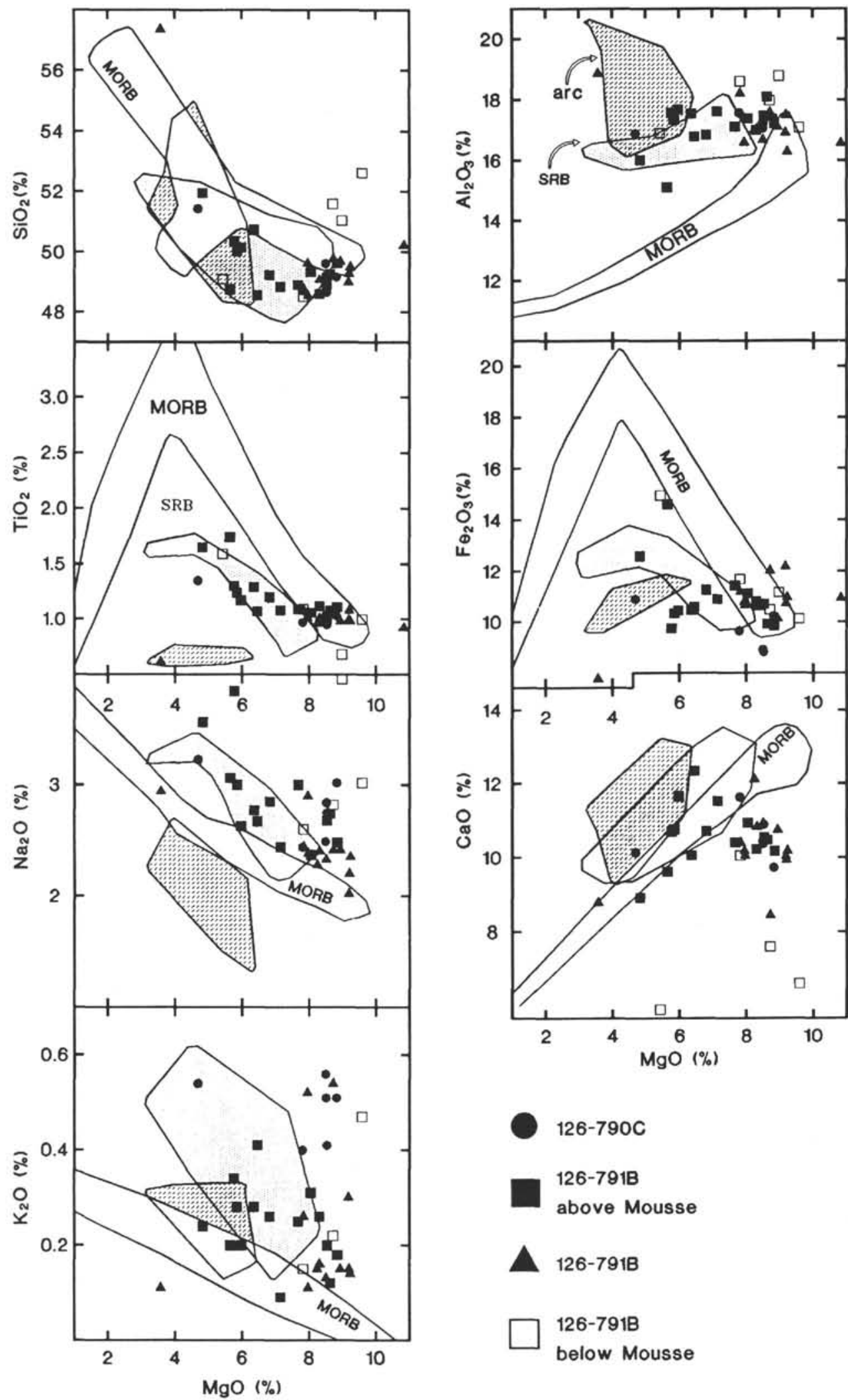

$126-790 \mathrm{C}$

126-791B

above Mousse

$126-7918$

126-791B

below Mousse

Figure 8. Major element composition of basement basalts from Sites 790 and 791 . The fields for MORB, Quaternary Izu Arc (arc), and Sumisu Rift basalts (SRB) are from Hochstaedter et al. (1990a). 


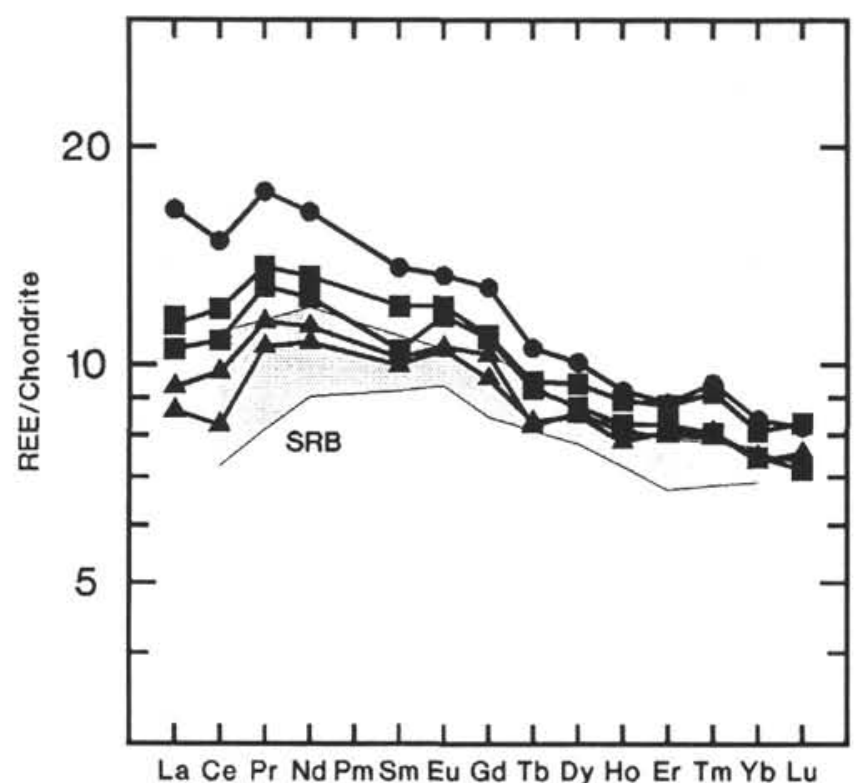

Figure 9. Chondrite-normalized REE patterns for basement basalts from Sites 790 and 791. The field for Sumisu Rift basalts is from Hochstaedter et al. (1990b). Filled circles represent Site 790 basalts, filled squares are Site 791 basalts, and filled triangles are Site 791 mousse lithic clasts. Not shown is basalt Sample 126-791B-78R-1 because of possible analytical problems (see text).

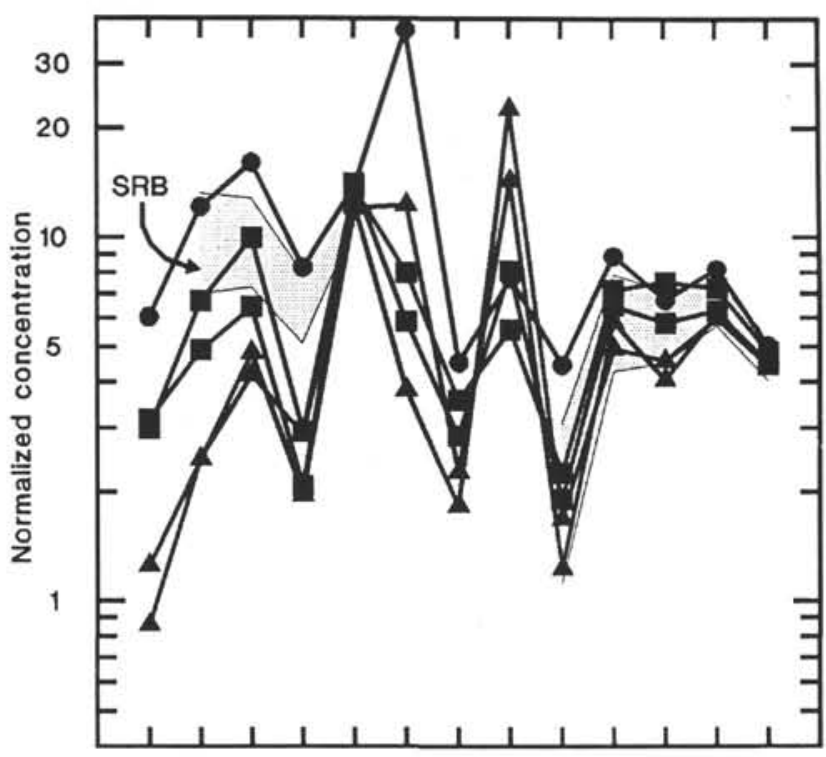

Cs Rb K Ba Sr Pb Th U Nb Ce Zr Sm Yb

Figure 10. Normalized extended trace element diagram for basement basalts from Sites 790 and 791. Symbols as in Figure 9.

nents (e.g., dikes or other plums in the pudding) had always been present but began to be preferentially tapped as the rift developed.

Pumice eruptions during the last $130,000 \mathrm{yr}$ have been entirely low-K dacite-rhyolite in composition. Most of the pumice deposits are compositionally heterogeneous, either because of secondary reworking, or because the range in juvenile clasts usually is as great as that in the 1952 eruption of nearby Myojinsho volcano.

No simple correlation exists between clast composition and tectonic environment. Clasts with rift-type compositions occur in pre-rift debris flows in the arc. Clasts with arc-type compositions occur in the

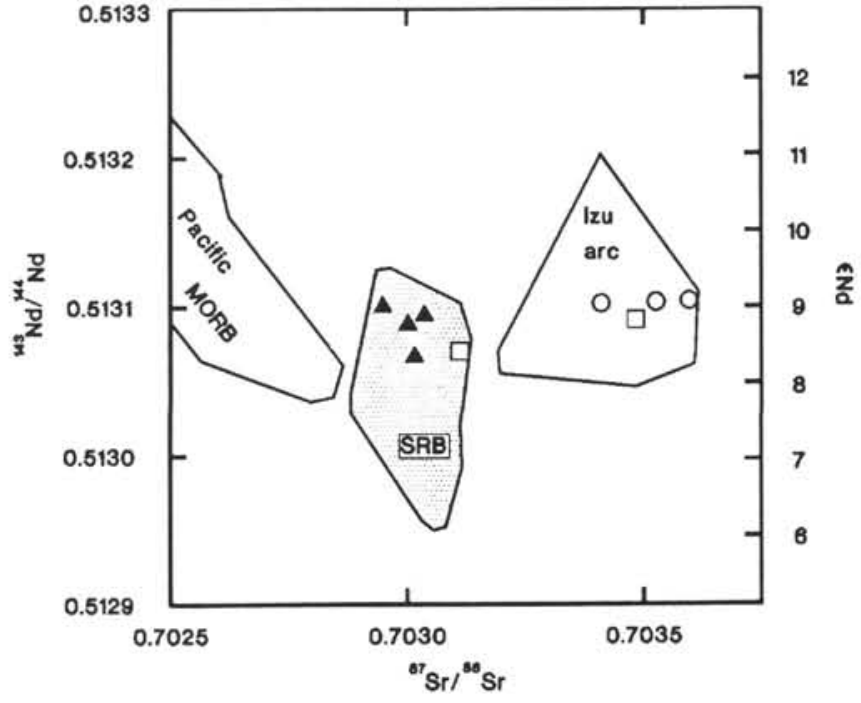

Figure 11. Sr and Nd isotope ratios for arc and rift samples from Leg 126. The fields for Pacific MORB, the Quaternary Izu Arc, and Sumisu Rift basalts are from Hochstaedter et al. (1990b). Open circles are for Quaternary arc pumices, open squares are for Pliocene arc pumices, and solid triangles are for rift basement basalts and lithic clasts.

rift; those near the top at Sites 790 and 791 clearly are in arc-derived debris, but those in the basement of Site 791 (Group 791-b) are ambiguous. Their chemistry and texture may indicate proximal deposition in the arc and, therefore, that pre-rift basement had been reached. However, we interpret them as analogous in depositional mechanism to those near the top, and we attribute the difference in texture to diagenetic flattening.

Variations of magma composition before, during, and after arc rifting are broadly similar in the two best documented cases, Sumisu and Lau. In both, slab components are more in evidence in arc magmas after rifting begins than before. In both, the earliest basalts in the backarc rifts are BABB or even MORB, not IAB. Sources characterized by old enrichments, which are not major contributors to the arc magmas, are present in both backarcs.

\section{ACKNOWLEDGMENTS}

We thank B. Taylor, A. Nishimura, R. Hiscott, and M. Koyama for discussion and data that bear on these topics, K. Collerson and R. Williams for assistance with mass spectrometry, E. Widom for assistance with column chemistry, and P. Fryer and R. Hickey-Vargas for helpful reviews. Simon Jackson oversaw the ICP-MS analyses at Memorial University.

\section{REFERENCES}

Allen, J. F., Sack, R. O., and Batiza, R., 1988. Cr-rich spinels as petrogenetic indicators: MORB-type lavas from the Lamont Seamount chain, eastern Pacific. Am. Mineral., 73:741-753.

Allen, R. L., 1990. Subaqueous welding or alteration, diagenetic compaction, and tectonic dissolution? IAVCEI Congress, Mainz, Abstracts.

Carrigan, C. R., and Eichelberger, J. C., 1990. Zoning of magmas by viscosity in volcanic conduits. Nature, 343:248-251.

Cole, J. W., Gill, J. B., and Woodhall, D., 1985. Petrologic history of the Lau Ridge, Fiji. In Scholl, D., and Vallier, T. (Eds.), Geology and Offshore Resources of Pacific Island Arcs-Tonga Region. Circum-Pac. Counc. Energy Miner. Resour., Earth Sci. Ser., 2:379-414.

Cole, J. W., Graham, I. J., and Gibson, I. L., 1990. Magmatic evolution of Late Cenozoic volcanic rocks of the Lau Ridge, Fiji. Contrib. Mineral. Petrol., 104:540-554.

Cousens, B. L., Allan, J. F., and Gorton, M. P., 1990. Sediment contamination of the mantle beneath the Sea of Japan, ODP Leg 127. Eos, 71:1704. 
Table 9. Representative plagioclase analyses.

\begin{tabular}{|c|c|c|c|c|c|c|c|}
\hline \multirow[t]{2}{*}{$\begin{array}{l}\text { Sample } \\
\text { Interval (cm) }\end{array}$} & \multicolumn{2}{|c|}{$\begin{array}{c}126-791 \mathrm{~B}-60 \mathrm{R}-1 \\
62-64\end{array}$} & \multicolumn{2}{|c|}{$\begin{array}{c}|26-79| B-63 R-1 \\
3 \mid-33\end{array}$} & \multicolumn{2}{|c|}{$\begin{array}{c}126-791 B-53 R-1 \\
10-12\end{array}$} & \multirow{2}{*}{$\frac{1896-1}{C}$} \\
\hline & c & $\mathbf{R}$ & c & $\mathbf{R}$ & $C(S)$ & $\mathbf{R}$ & \\
\hline \multicolumn{8}{|l|}{ Major elements (wt\%): } \\
\hline $\mathrm{SiO}_{2}$ & 47.46 & 48.27 & 47.40 & 46.59 & 48.99 & 49.12 & 46.74 \\
\hline$\underset{\mathrm{F} e O}{\mathrm{Al}_{2} \mathrm{O}_{3}}$ & 33.44 & 32.86 & 33.23 & 33.31 & 32.81 & 32.53 & 33.46 \\
\hline $\mathrm{CaO}$ & & & & 0.6 & & & 0.84 \\
\hline $\mathrm{Na}_{2} \mathrm{O}$ & 1.77 & $\begin{array}{r}16.96 \\
2.34\end{array}$ & 17.35 & $\begin{aligned} 17.92 \\
1.54\end{aligned}$ & $\begin{array}{l}16.51 \\
2.64\end{array}$ & 16.64 & 17.84 \\
\hline Sum & 100,91 & 101.06 & 100.45 & 99.99 & 101.79 & 101.42 & 100.42 \\
\hline Trace elements (ppm): & \multicolumn{7}{|c|}{ Cations based on 8 oxygens } \\
\hline & 2.168 & 2.199 & 2.173 & 2.151 & 2.215 & 2.226 & 2.150 \\
\hline Al & 1.800 & 1.7 & 1.796 & 1.81 & 1.748 & 1.7 & 1.814 \\
\hline $\mathrm{Fe}$ & 0.021 & 0.0 & 0.023 & 0.02 & 0.032 & 0.0 & 0.032 \\
\hline $\mathrm{Ca}$ & 0.866 & 0.828 & 0.861 & 0.886 & 0.800 & 0.808 & 0.879 \\
\hline $\mathrm{Na}$ & 0.157 & 0.207 & 0.150 & 0.138 & 0.231 & 0.209 & 0.137 \\
\hline Sum & 5.011 & 5.022 & 5.004 & 5.012 & 5.026 & 5.009 & 5.012 \\
\hline An & 84.68 & 80.02 & 85.15 & 86.54 & 77.56 & 79.44 & 86.49 \\
\hline
\end{tabular}

Note: $\mathrm{C}=$ core, $\mathrm{R}=\mathrm{rim}$, and $\mathrm{S}=$ sieved.

Table 10. Representative clinopyroxene analyses.

\begin{tabular}{|c|c|c|c|c|c|}
\hline \multirow[t]{2}{*}{ Sample } & \multicolumn{3}{|c|}{$126-791 B-53 R-1,10-12$} & \multicolumn{2}{|c|}{$1896-1$} \\
\hline & $\mathrm{C}$ & $\mathbf{R}$ & C & $\mathrm{C}$ & $\mathbf{R}$ \\
\hline $\begin{array}{l}\text { Major elments (wt\%): } \\
\mathrm{SiO}_{2} \\
\mathrm{TiO}_{2} \\
\mathrm{Al}_{2} \mathrm{O}_{3} \\
\mathrm{FeO} \\
\mathrm{MnO} \\
\mathrm{MgO} \\
\mathrm{CaO} \\
\mathrm{Sum}\end{array}$ & $\begin{array}{r}51.61 \\
0.76 \\
3.87 \\
5.81 \\
0.33 \\
15.91 \\
22.68 \\
100.97\end{array}$ & $\begin{array}{r}50.41 \\
1.00 \\
4.90 \\
6.69 \\
0.32 \\
15.15 \\
22.39 \\
100.86\end{array}$ & $\begin{array}{r}50.50 \\
1.09 \\
3.84 \\
9.09 \\
0.30 \\
14.98 \\
21.14 \\
100.94\end{array}$ & $\begin{array}{r}50.96 \\
0.94 \\
3.97 \\
8.28 \\
0.29 \\
15.12 \\
21.61 \\
101.17\end{array}$ & $\begin{array}{r}48.91 \\
1.74 \\
6.01 \\
10.49 \\
0.39 \\
14.04 \\
20.74 \\
102.32\end{array}$ \\
\hline $\begin{array}{l}\text { Trace elements (ppm): } \\
\mathrm{Si} \\
\mathrm{Ti} \\
\mathrm{Al} \\
\mathrm{Fe} \\
\mathrm{Mn} \\
\mathrm{Mg} \\
\mathrm{Ca} \\
\mathrm{Sum}\end{array}$ & $\begin{array}{l}\text { Cations } \\
1.884 \\
0.021 \\
0.167 \\
0.177 \\
0.010 \\
0.866 \\
0.887 \\
4.012\end{array}$ & $\begin{array}{l}\text { ased on } 6 \\
1.851 \\
0.028 \\
0.212 \\
0.205 \\
0.010 \\
0.829 \\
0.881 \\
4.016\end{array}$ & $\begin{array}{l}\text { xygens } \\
1.867 \\
0.030 \\
0.167 \\
0.281 \\
0.009 \\
0.826 \\
0.838 \\
4.019\end{array}$ & $\begin{array}{l}1.873 \\
0.026 \\
0.172 \\
0.255 \\
0.009 \\
0.828 \\
0.851 \\
4.015\end{array}$ & $\begin{array}{l}1.797 \\
0.048 \\
0.260 \\
0.322 \\
0.012 \\
0.769 \\
0.816 \\
4.025\end{array}$ \\
\hline $\begin{array}{l}\text { En } \\
\text { Fs } \\
\text { Wo }\end{array}$ & $\begin{array}{r}44.85 \\
9.19 \\
45.96\end{array}$ & $\begin{array}{l}43.29 \\
10.73 \\
45.99\end{array}$ & $\begin{array}{l}42.47 \\
14.46 \\
43.08\end{array}$ & $\begin{array}{l}42.83 \\
13.16 \\
44.01\end{array}$ & $\begin{array}{l}40.31 \\
16.90 \\
42.80\end{array}$ \\
\hline
\end{tabular}

Note: $\mathrm{C}=$ core and $\mathrm{R}=$ rim.

Table 11. Representative olivine analyses.

\begin{tabular}{|c|c|c|c|c|c|c|c|}
\hline \multirow[t]{2}{*}{ Sample } & \multicolumn{2}{|c|}{$126-791 \mathrm{~B}-60 \mathrm{R}-1.62$} & \multicolumn{2}{|c|}{$791 B-63 R-1,53$} & \multirow{2}{*}{$\frac{53-10^{\circ}}{\mathrm{C}}$} & \multirow{2}{*}{$\frac{\mathrm{D} 1-2}{\mathrm{C}}$} & \multirow{2}{*}{$\frac{1896-1}{G}$} \\
\hline & C & $R$ & c & R & & & \\
\hline \multicolumn{8}{|l|}{ Major elements (wt\%): } \\
\hline $\mathrm{SiO}_{2}$ & 40.10 & 39.55 & 41.48 & 40.86 & 38.22 & 40.04 & 38.97 \\
\hline $\mathrm{FeO}$ & 12.52 & 14.58 & 14.83 & 17.90 & 21.80 & 16.58 & 25.68 \\
\hline $\mathrm{MnO}$ & 0.27 & 0.32 & 0.37 & 0.41 & 0.45 & 0.32 & 0.60 \\
\hline $\mathrm{MgO}$ & 46.48 & 45.02 & 46.74 & 43.82 & 38.12 & 44.41 & 37.75 \\
\hline $\mathrm{CaO}$ & 0.39 & 0.38 & 0.45 & 0.54 & 0.42 & 0.42 & 0.49 \\
\hline Sum & 99.76 & 99.85 & 103.87 & 103.53 & 99.01 & $101 . \pi$ & 103.49 \\
\hline Trace elements (ppm): & \multicolumn{7}{|c|}{ Cations based on 4 oxygens } \\
\hline $\mathrm{Si}$ & 0.999 & 0.994 & & & 1.004 & 0.996 & \\
\hline $\mathrm{Fe}$ & 0.261 & 0.307 & 0.299 & 0.368 & 0.479 & 0.345 & 0.548 \\
\hline $\mathrm{Mn}$ & 0.006 & 0.007 & 0.008 & 0.009 & 0.010 & 0.007 & 0.013 \\
\hline $\mathrm{Mg}_{\mathrm{g}}$ & 1.726 & 1.687 & $\begin{array}{l}0.608 \\
1.681\end{array}$ & 1.604 & 1.492 & 1.646 & 1.436 \\
\hline $\mathrm{Ca}$ & 0.010 & 0.010 & 0.012 & 0.014 & 0.012 & 0.011 & 0.013 \\
\hline Sum & 3.001 & 3.006 & 2.999 & 2.997 & 2.996 & 3.004 & 3.005 \\
\hline Fo & 86.87 & 84.62 & 84.89 & 81.35 & 75.71 & 82.68 & 72.38 \\
\hline
\end{tabular}

Note: $\mathrm{C}=$ core, $\mathrm{R}=\mathrm{rim}$, and $\mathrm{G}=$ groundmass

-53-10 $=126-791 \mathrm{~B}-53 \mathrm{R} I, 10-12 \mathrm{~cm}$.

Dick, H.J.B., and Bullen, T., 1984. Chromian spinel as a petrogenetic indicator in abyssal and alpine-type peridotites and spatially associated lavas. Contrib. Mineral. Petrol., 86:54-76.

Evensen, N. M., Hamilton, P. J., and O'Nions, R. K., 1978. Rare-earth abundances on chondritic meteorites. Geochim. Cosmochim. Acta, 42:1199-1212.

Fisher, R. V., and Schmincke, H.-U., 1984. Pyroclastic Rocks: Berlin (Springer-Verlag).
Table 12. Representative chromian spinel analyses.

\begin{tabular}{|c|c|c|c|c|c|}
\hline \multirow[t]{2}{*}{ Sample } & \multicolumn{2}{|c|}{$126-791 \mathrm{~B}-60 \mathrm{R}-1,62$} & \multicolumn{2}{|c|}{ 126-791B-63R-1, 53} & \multirow{2}{*}{$\frac{\text { D1-2 }}{1}$} \\
\hline & 1 & 1 & I & 1 & \\
\hline \multicolumn{6}{|l|}{ Major elements (wt\%): } \\
\hline $\mathrm{TiO}_{2}$ & 0.90 & $\begin{array}{r}80.80 \\
0.91\end{array}$ & $\begin{array}{r}84.00 \\
1.11\end{array}$ & 84.00 & $\begin{array}{r}02.00 \\
1.84\end{array}$ \\
\hline $\mathrm{Al}_{2} \mathrm{O}_{3}$ & 29.73 & 30.86 & 29.98 & 28.94 & 21.55 \\
\hline $\mathrm{Cr}_{2} \mathrm{O}_{3}$ & 29.94 & 26.64 & 26.18 & 25.68 & 28.02 \\
\hline $\mathrm{FeO}$ & 14.70 & 15.26 & 17.85 & 17.86 & 20.30 \\
\hline${ }^{\mathrm{C}} \mathrm{Fe}_{2} \mathrm{O}_{3}$ & 9.92 & 10.68 & 13.33 & 12.28 & 17.46 \\
\hline $\mathrm{MnO}$ & 0 & 0 & 0 & 0.20 & 0 \\
\hline $\mathrm{MgO}$ & 14.85 & 14.31 & 13.26 & 11.92 & 10.82 \\
\hline Sum & 100.04 & 98.66 & 101.71 & 97.58 & 99.99 \\
\hline Trace elements (ppm): & \multicolumn{5}{|c|}{ Cations based on stoichiometry } \\
\hline $\mathrm{Ti}$ & 0.020 & 0.020 & 0.025 & 0.016 & 0.044 \\
\hline Al & 1.038 & 1.088 & 1.043 & 1.054 & 0.800 \\
\hline & 0.701 & 0.630 & 0.611 & 0.627 & 0.698 \\
\hline $\mathrm{Fe}^{2+}$ & 0.364 & 0.382 & 0.441 & 0.462 & 0.535 \\
\hline $\mathrm{Fe}^{3+}$ & 0.221 & 0.241 & 0.296 & 0.286 & 0.414 \\
\hline $\mathrm{Mn}$ & 0 & 0 & 0 & 0.005 & \\
\hline $\mathrm{Mg}$ & 0.656 & 0.638 & 0.584 & 0.549 & 0.508 \\
\hline Sum & 3.000 & 3.000 & 3.000 & 3.000 & 3.000 \\
\hline Mg\# & 0.643 & 0.626 & 0.570 & 0.543 & 0.487 \\
\hline Cri & 0.403 & 0.367 & 0.369 & 0.373 & 0.466 \\
\hline $\mathrm{Fe}^{3 / 4} \#$ & 0.11 & 0.12 & 0.15 & 0.15 & 0.22 \\
\hline
\end{tabular}

Note: $\mathbf{I}$ = inclusion

"Fo = Forsterite content of enclosing olivine core; see Table 11 .

${ }^{b}$ Probe analysis.

${ }^{\mathrm{C}} \mathrm{Fe}_{2} \mathrm{O}_{2}$ calculated from charge balance.

Table 13. Representative Fe-Ti oxide analyses.

\begin{tabular}{|c|c|c|c|c|c|}
\hline \multirow[t]{2}{*}{ Sample } & \multicolumn{4}{|c|}{ 126-791B-53R-1, 10-12 } & \multirow{2}{*}{$\frac{1896-1}{G}$} \\
\hline & I & I & G & G & \\
\hline $\begin{array}{l}\text { Major elements (wt\%): } \\
\mathrm{TiO}_{2} \\
\mathrm{Cr}_{2} \mathrm{O}_{3} \\
\mathrm{Al}_{2} \mathrm{O}_{3} \\
\mathrm{Fe}_{2} \mathrm{O}_{3} \\
\mathrm{FeO} \\
\mathrm{MnO} \\
\mathrm{MgO} \\
\mathrm{CaO} \\
\mathrm{Sum}\end{array}$ & $\begin{array}{c}{ }^{2} 8.47 \\
6.6 \\
9.04 \\
31.36 \\
40.10 \\
0.43 \\
5.36 \\
0 \\
101.35\end{array}$ & $\begin{array}{r}{ }^{2} 10.80 \\
6.13 \\
9.46 \\
29.97 \\
37.37 \\
0.38 \\
5.93 \\
0 \\
100.04\end{array}$ & $\begin{array}{r}{ }^{a} 14.51 \\
0 \\
2.01 \\
37.41 \\
45.81 \\
0.49 \\
0.77 \\
0.35 \\
101.35\end{array}$ & $\begin{array}{r}{ }^{a} 1.44 \\
0.14 \\
2.64 \\
45.21 \\
40.89 \\
0.38 \\
1.92 \\
0.22 \\
102.84\end{array}$ & $\begin{array}{c}10.72 \\
0 \\
5.58 \\
45.09 \\
38.45 \\
0 \\
3.42 \\
0 \\
103.26\end{array}$ \\
\hline $\begin{array}{l}\text { Trace elements (ppm): } \\
\mathrm{Ti} \\
\mathrm{Cr} \\
\mathrm{Al}^{3+} \\
\mathrm{Fe}^{3+} \\
\mathrm{Fe}^{2+} \\
\mathrm{Mn} \\
\mathrm{Mg} \\
\mathrm{CaO} \\
\mathrm{Sum}\end{array}$ & $\begin{array}{l}\mathrm{C} \\
0.279 \\
0.207 \\
0.444 \\
1.003 \\
1.153 \\
0.015 \\
0.333 \\
0 \\
3.432\end{array}$ & $\begin{array}{r}\text { ions basec } \\
0.357 \\
0.193 \\
0.466 \\
0.942 \\
1.055 \\
0.013 \\
0.370 \\
0 \\
3.396\end{array}$ & $\begin{array}{l}4 \text { oxyg } \\
0.507 \\
0.000 \\
0.110 \\
0.156 \\
1.575 \\
0.019 \\
0.053 \\
0.017 \\
3.420\end{array}$ & $\begin{array}{l}0.394 \\
0.005 \\
0.142 \\
0.413 \\
1.422 \\
0.015 \\
0.131 \\
0.011 \\
3.522\end{array}$ & $\begin{array}{l}0.346 \\
0.000 \\
0.282 \\
1.368 \\
1.298 \\
0 \\
0.219 \\
0 \\
3.513\end{array}$ \\
\hline $\begin{array}{l}\text { \%Mgt } \\
\text { \%Ulvsp } \\
\text { \%Other }\end{array}$ & $\begin{array}{l}50.4 \\
18.1 \\
31.6\end{array}$ & $\begin{array}{l}46.6 \\
17.0 \\
36.4\end{array}$ & $\begin{array}{r}50.7 \\
44.5 \\
4.8\end{array}$ & $\begin{array}{r}60.2 \\
33.5 \\
6.3\end{array}$ & $\begin{array}{l}58.4 \\
29.5 \\
12.1\end{array}$ \\
\hline
\end{tabular}

Note: $\mathrm{I}=$ inclusion and $\mathrm{G}=$ groundmass.

a Probe analyses.

${ }^{b} \mathrm{Fe}_{2} \mathrm{O}_{3}$ calculated after Carmichael (1967).

Fryer, P., Taylor, B., Langmuir, C. H., and Hochstaedter, A. G., 1990. Petrology and geochemistry of lavas from the Sumisu and Torishima backarc rifts. Earth Planet. Sci. Lett., 100:161-178.

Gill, J., Torssander, P., Lapierre, H., Taylor, R., Kaiho, K., Koyama, M., Kusakabe, M., Aitchison, J., Cisowski, S., Dadey, K., Fujioka, K., Klaus, A., Lovell; M., Marsaglia, K., Pezard, P., Taylor, B., and Tazaki, K., 1990. Explosive deep water basalt in the Sumisu backarc rift. Science, 248:1214-1217.

Gill, J., and Whelan, P., 1989. Early rifting of an oceanic island arc (Fiji) produced shoshonitic to tholeiitic basalts. J. Geophys. Res., 94:4561-4578.

Gill, J. B., 1976a. Composition and ages of Lau basin and ridge volcanic rocks: implications for evolution of an interarc basin and remnant arc. Geol. Soc. Am. Bull., 87:1384-1395.

1976b. From island arc to oceanic islands: Fiji, southwestern Pacific. Geology, 4:123-126.

, 1987. Early geochemical evolution of an oceanic island arc and backarc: Fiji and the South Fiji Basin. J. Geol., 95:589-615.

Govindaraju, K., 1990. 1989 compilation of working values and sample description for 272 geostandards. Geostand. Newsl., 13:1-113. 


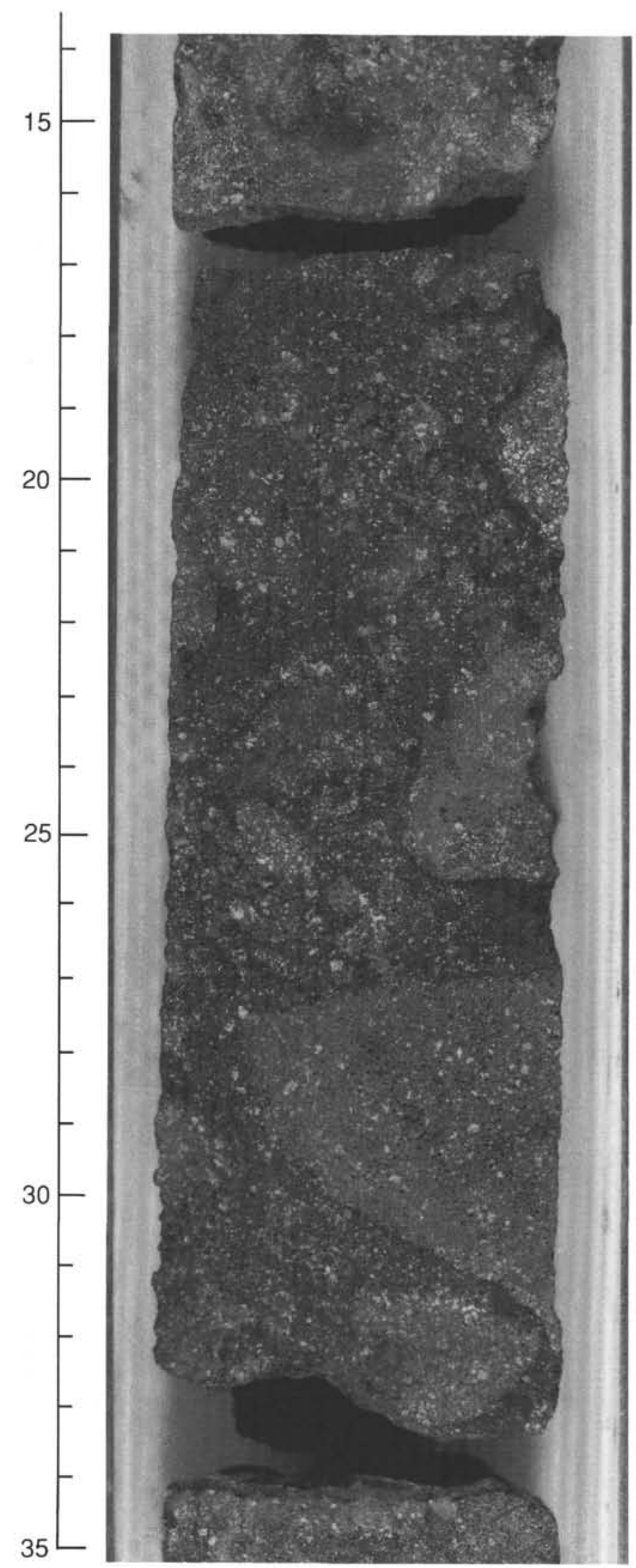

Figure 12. Photograph of core of the explosion breccia ("mousse"); Section 791B-73R-2. This is from the altered base of the section so that the lithic clasts stand out visually and are particularly abundant. The exceptional sample with a secondary magnetic overprint (see Koyama et al., this volume, fig. 2C) and possibly arc-like composition is from slightly lower in this core section.
Hawkins, J. W., and Melchior, J. T., 1985. Petrology of Mariana Trough and Lau Basin basalts. J. Geophys. Res., 90:11431-11468.

Hochstaedter, A. G., Gill, J. B., Kusakabe, M., Newman, S., Pringle, M., Taylor, B., and Fryer, P., 1990a. Volcanism in the Sumisu Rift. I. Major element, volatile, and stable isotope geochemistry. Earth Planet. Sci. Lett., 100:179-194.

Hochstaedter, A. G., Gill, J. B., and Morris, J. D., 1990b. Volcanism in the Sumisu Rift. II. Subduction and non-subduction related components. Earth Planet. Sci. Lett., 100:195-209.

Hofmann, A. W., 1988. Chemical differentiation of the Earth: the relationship between mantle, continental crust, and oceanic crust. Earth Planet. Sci. Lett., 90:297-314.

Ikeda, Y., and Yuasa, M., 1989. Volcanism in nascent back-arc basins behind the Shichito Ridge and adjacent areas in the Izu-Ogasawara arc, northwest Pacific: evidence from mixing between E-type MORB and island arc magmas at the initiation of back arc rifting. Contrib. Mineral. Petrol., 101:377-393.

Jenner, G. A., Longerich, H. P., Jackson, S. E., and Fryer, B. J., 1990. ICP-MS: a powerful new tool for high precision trace element analysis in earth sciences: evidence from analysis of selected U.S.G.S. reference samples. Chem. Geol., 83:133-148.

Kuno, H. (Ed.), 1962. Catalogue of the Active Volcanoes of the World, Part II: Japan, Taiwan, and Marianas. Int. Assembly Volc. Chem. Earth's Interior.

Luhr, J. F., and Carmichael, I.S.E., 1985. Jorullo Volcano, Michoacan, Mexico (1759-1774): the earliest stages of fractionation in calc-alkaline magmas. Contrib. Mineral. Petrol., 90:142-161.

Miyajima, H. T., Yoshida, T., and Aoki, K., 1985. Geochemical study of the Higashi-Izu monogenetic volcano group. Rep. Nuclear Res. Inst., 18:158-174.

Murakami, F., and Ishihara, T., 1985. Submarine calderas discovered in the northern part of the Ogasawara Arc. Earth Monthly, 7:638-646.

Nishimura, A., Marsaglia, K. M., Rodolfo, K. S., Collela, A., Hiscott, R. N., Tazaki, K., Gill, J. B., Janecek, T., Firth, J., Isminger-Kelso, M., Herman, Y., Taylor, R. N., Taylor, B., Fujioka, K., and Leg 126 Scientific Party, 1991. Pliocene-Quaternary submarine pumice deposits in the Sumisu Rift area, Izu-Bonin arc. In Fisher, R. V., and Smith, G. A. (Eds.), Sedimentation in Volcanic Settings. Spec. Publ.-Soc. Econ. Paleontol. Mineral., 45:201-208.

Nohoda, S., and Wasserburg, G. J., 1981. Nd and Sr isotopic study of volcanic rocks from Japan. Earth Planet. Sci. Lett., 52:264-276.

Notsu, K., Isshiki, N., and Hirano, M., 1983. Comprehensive strontium isotope study of Quaternary volcanic rocks from the Izu-Ogasawara Arc. Geochem. J., 17:289-302.

Parson, L. M., Pearce, J. A., Murton, B. J., Hodkinson, R. A., Bloomer, S., Ernewein, M., Huggett, Q. J., Miller, S., Johnson, L., Rodda, P., and Helu, S., 1990. Role of ridge jumps and ridge propagation in the tectonic evolution of the Lau back-arc basin, southwest Pacific. Geology, 18:470-473.

Roedder, R. L., and Emslie, R. F., 1970. Olivine-liquid equilibrium. Contrib. Mineral. Petrol., 29:275-289.

Salter, V.J.M., and Hart, S. R., in press. The mantle sources of ocean ridges, islands and arcs: the Hf-isotope connection. Earth Planet. Sci. Lett.

Saunders, A. D., and Tarney, J., 1984. Geochemical characteristics of basaltic volcanism within back-arc basins. In Kokelaar, B. P., and Howells, M. F. (Eds.), Marginal Basin Geology. Spec. Publ., Geol. Soc. London, 16:59-76.

Stern, R. J., Bloomer, S. H., Lin, P.-N., Ito, E., and Morris, J., 1988. Shoshonitic magmas in nascent arcs: new evidence from submarine volcanoes in the northern Marianas. Geology, 16:426-430.

Stork, A. L., Smith, D. K., and Gill, J. B., 1987. Evaluation of geochemical reference standards by X-ray fluorescence analysis. Geostand. Newsl., 11:107-113.

Storms, M. A., Natland, J. H., et al., 1991. Proc. ODP, Init. Repts., 132: College Station, TX (Ocean Drilling Program).

Taylor, B., Brown, G., Fryer, P., Gill, J. B., Hochstaedter, A. G., Hotta, H., Langmuir, C. H., Leinen, M., Nishimura, A., and Urabe, T., 1990. Alvin-SeaBeam studies of the Sumisu Rift, Izu-Bonin Arc. Earth Planet. Sci. Lett., 100:127-147.

Volpe, A. M., Macdougall, J. D., and Hawkins, J. W., 1988. Lau Basin basalts (LBB): trace element and $\mathrm{Sr}-\mathrm{Nd}$ isotopic evidence for heterogeneity in backarc basin mantle. Earth Planet. Sci. Lett., 90:174-186.

Wark, D. A., Kempter, K. A., and McDowell, F. W., 1990. Evolution of waning, subduction-related magmatism, northern Sierra Madre Occidental, Mexico. Geol. Soc. Am. Bull., 102:1555-1564.

Yuasa, M., 1985. Sofugan Tectonic Line, a new tectonic boundary separating northern and southern parts of the Ogasawara (Bonin) Arc, northwest Pacific. In Nasu, N., Kobayashi, K., Uyeda, S., Kushiro, I., and Kagami, H. (Eds.), Formation of Active Ocean Margins: Tokyo (Terra Scientific), 483-496.

Date of initial receipt: 2 January 1991

Date of acceptance: 20 August 1991

Ms 126B-125 


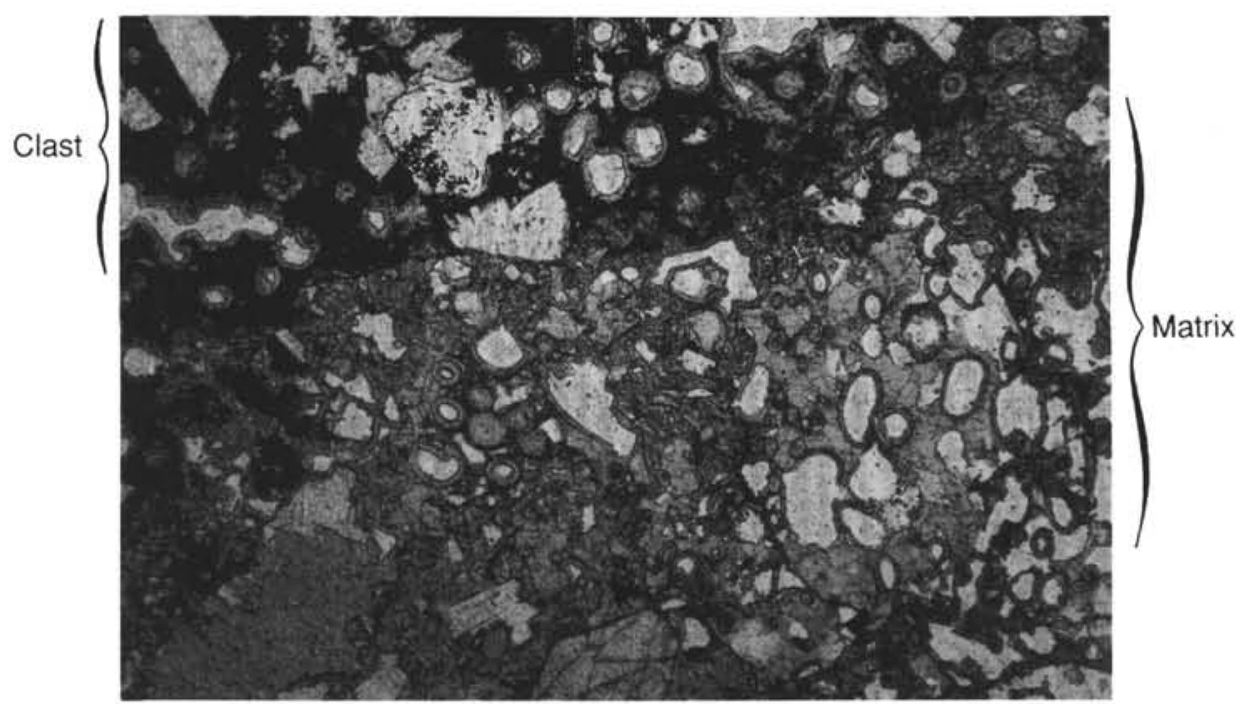

Figure 13. Photomicrograph of breccia in transmitted light showing the boundary between lithic clast (dark, upper left) and matrix (light, lower right). The euhedral plagioclase phenocrysts of the lithic clast are clearly visible as are its 0.2 -mm vesicles lined with 1-2-mm-thick smectite. The black tachylitic groundmass consists of devitrified glass, plagioclase microlites, and submicroscopic crystals. Euhedral plagioclase and olivine crystals are visible in the matrix component, where the size and linings of vesicles are approximately the same as in the clast. The matrix component is lighter in color because its glass is fresh sideromelane. The contact between matrix and clast exhibits complex 0.05-mm-wide zones of alteration in the lower left and upper right of the figure. Sample 126-791B-62R-1, Piece 5b, for which a chemical analysis is given in Table 7; $\times 40$ magnification; the field of view is $3 \mathrm{~mm}$ in the long dimension.

Table 14. Chemical analyses of anhydrous Sumisu Rift rhyolites collected using Alvin.

\begin{tabular}{|c|c|c|c|c|c|c|c|}
\hline \multirow[b]{2}{*}{ Sample } & \multicolumn{4}{|c|}{ Type A } & \multicolumn{3}{|c|}{ Type B } \\
\hline & $1895-14$ & $1895-10$ & $1888-10^{a}$ & $1888-13^{a}$ & $1888-4$ & $1888-8$ & $1895-4$ \\
\hline \multicolumn{8}{|c|}{ Major elements (wt\%) } \\
\hline $\mathrm{SiO}_{2}$ & 73.02 & 73.20 & 72.47 & 70.95 & 72.62 & 72.45 & 73.81 \\
\hline $\mathrm{TiO}_{2}$ & 0.42 & 0.42 & 0.41 & 0.40 & 0.39 & 0.39 & 0.35 \\
\hline $\mathrm{Al}_{2} \mathrm{O}_{3}$ & 14.36 & 14.43 & 14.52 & 14.22 & 14.63 & 14.55 & 13.97 \\
\hline $\mathrm{Fe}_{2} \mathrm{O}_{3}$ & 2.53 & 2.53 & 2.78 & 2.75 & 2.81 & 2.85 & 2.61 \\
\hline $\mathrm{MgO}$ & 0.49 & 0.41 & 0.37 & 0.32 & 0.28 & 0.31 & 0.24 \\
\hline $\mathrm{CaO}$ & 2.02 & 1.97 & 1.89 & 2.04 & 1.93 & 1.89 & 1.67 \\
\hline $\mathrm{Na}_{2} \mathrm{O}$ & 6.07 & 5.97 & 6.24 & 5.66 & 6.27 & 6.40 & 6.08 \\
\hline $\mathrm{K}_{2} \mathrm{O}$ & 1.05 & 1.01 & 1.06 & 1.68 & 1.03 & 1.12 & 1.20 \\
\hline $\mathrm{P}_{2} \mathrm{O}_{5}$ & 0.06 & 0.06 & 0.06 & 0.06 & 0.05 & 0.05 & 0.06 \\
\hline $\mathrm{H}_{2} \mathrm{O}$ & - & - & 0.20 & 0.91 & - & - & - \\
\hline Sum & 98.55 & 98.74 & 99.37 & 99.36 & 100.13 & 98.28 & 98.04 \\
\hline \multirow{2}{*}{\multicolumn{8}{|c|}{ Trace elements (ppm): }} \\
\hline & & & 10 & 9 & & & \\
\hline $\mathrm{Rb}$ & 17 & 17 & 18 & 30 & 23 & 23 & 23 \\
\hline $\mathrm{Ba}$ & 157 & 163 & 151 & 154 & 150 & 153 & 155 \\
\hline $\mathrm{Sr}$ & 169 & 163 & 139 & 136 & 132 & 132 & 113 \\
\hline $\mathrm{Zr}$ & 267 & 265 & 305 & 303 & 291 & 291 & 272 \\
\hline $\mathrm{Nb}$ & 4.6 & 4.4 & 5.4 & 4.6 & 4.7 & 5.7 & 4.7 \\
\hline $\mathrm{Y}$ & 65 & 60 & 68 & 72 & 69 & 68 & 71 \\
\hline $\mathrm{Ni}$ & 10 & 6 & 6 & 6 & 5 & 13 & 10 \\
\hline $\mathrm{Cr}$ & - & - & 1 & 1 & 1 & - & - \\
\hline $\mathrm{Sc}$ & 10 & 10 & 11 & 10 & 11 & 10 & 10 \\
\hline V & 一 & - & 7 & 6 & 6 & 一 & 4 \\
\hline $\mathrm{La}$ & 17 & 16 & 19 & 16 & 16 & 15 & 16 \\
\hline $\mathrm{Ce}$ & & & 40.0 & 38.9 & & & 40.9 \\
\hline $\mathrm{Nd}$ & & & 29.0 & 28.4 & & & 28.9 \\
\hline $\mathrm{Sm}$ & & & 7.9 & 7.7 & & & 7.8 \\
\hline $\mathrm{Eu}$ & & & 2.2 & 2.1 & & & 2.0 \\
\hline Gd & & & 9.2 & 8.9 & & & 8.9 \\
\hline Dy & & & 10.7 & 10.4 & & & 10.2 \\
\hline $\mathrm{Er}$ & & & 6.7 & 6.6 & & & 6.7 \\
\hline $\mathrm{Yb}$ & & & 7.3 & 7.2 & & & 6.7 \\
\hline
\end{tabular}

a Data from Hochstaedter et al. (1990a, 1990b). 


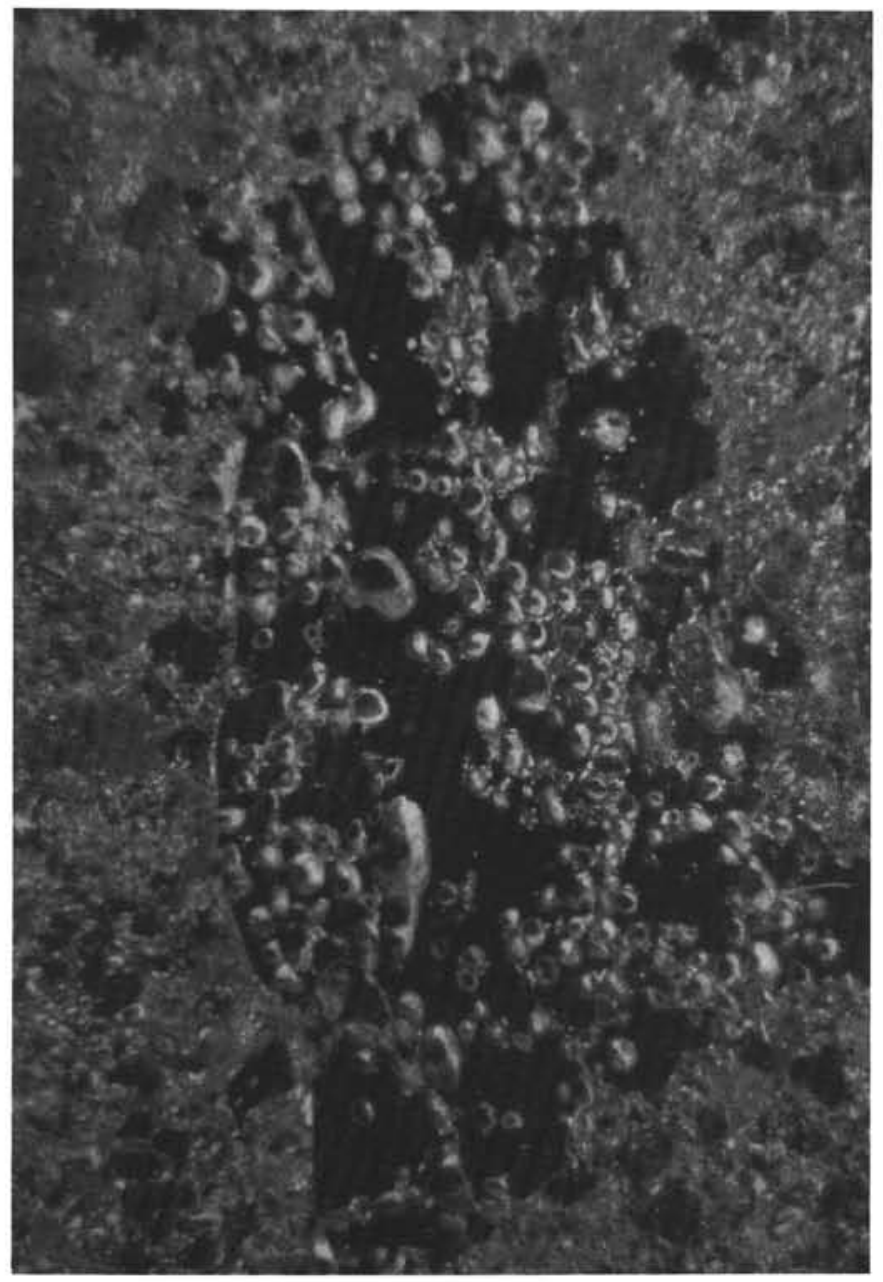

Figure 14. Photomicrograph of a glass clast in the matrix component. Vesiculation primarily occurs along fractures, leading to close-packing of vesicle and fragmentation of the glass clast. Sample 126-791B-63R-1, Piece $8 ; \times 200$ magnification; the field of view is $7.5 \mathrm{~mm}$ in the long dimension. 
A

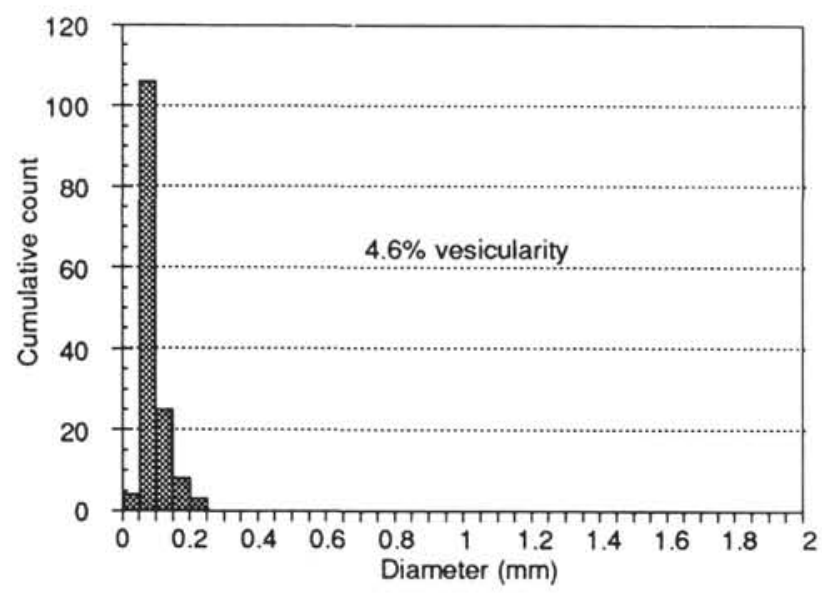

C

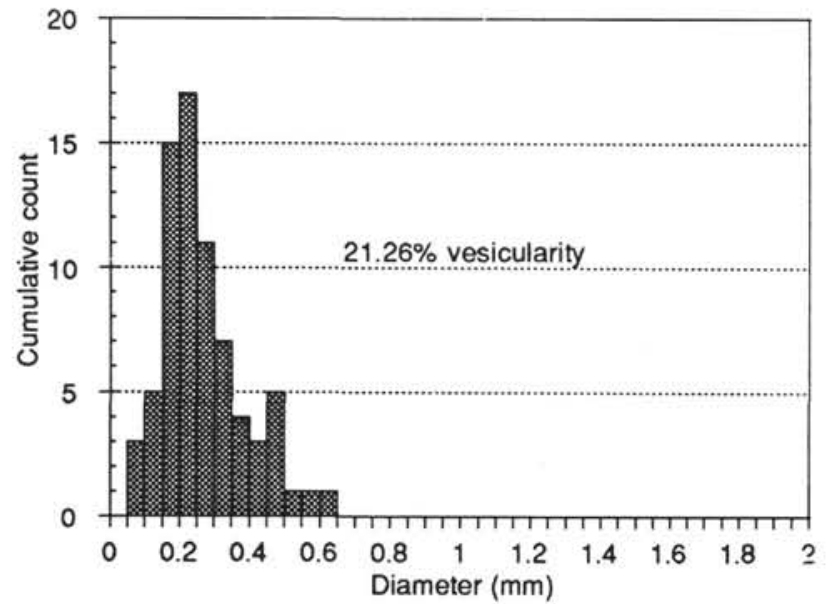

B

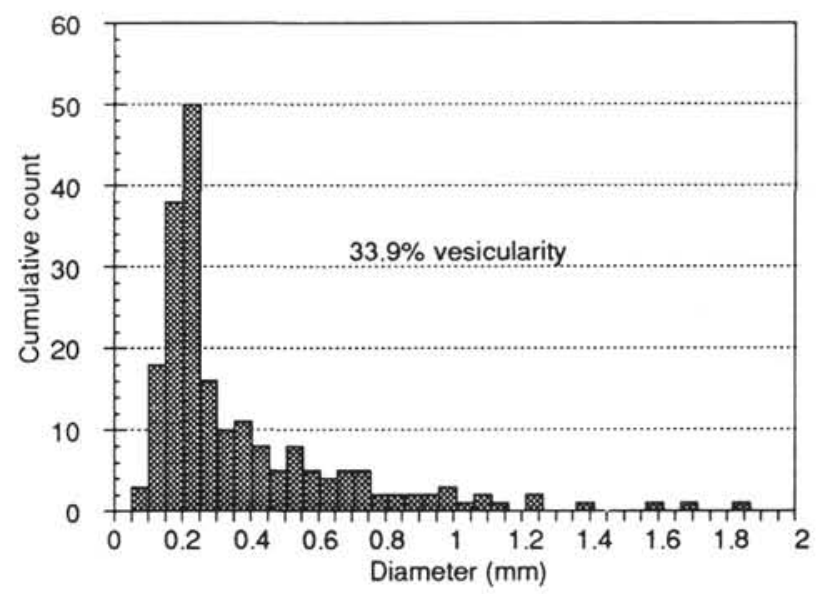

D

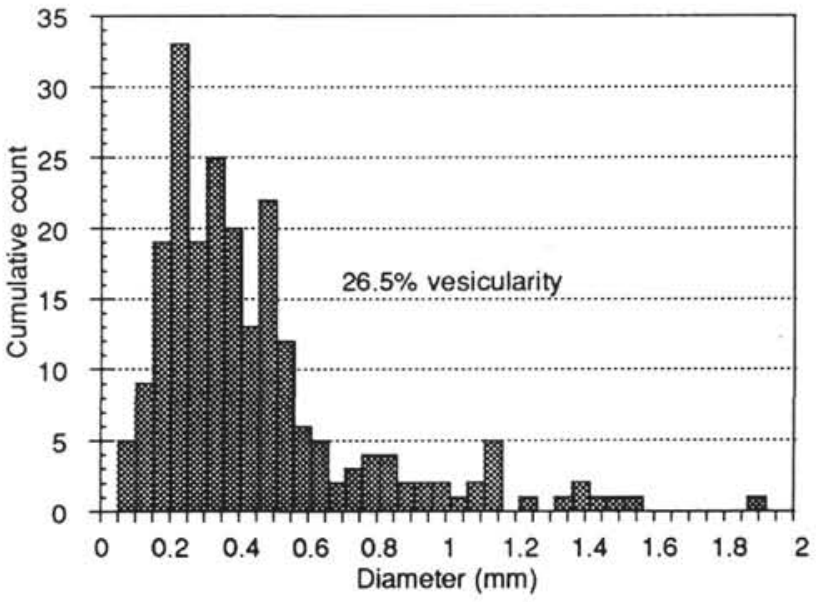

Figure 15. Vesicle size distribution in basaltic rocks in the basement of Site 791. Photomicrographs $8 \times 10.6 \mathrm{~mm}$ were analyzed using Image $1.29 \mathrm{q}$ software. The vertical axis of the histogram is raw, cumulative number of vesicles. The horizontal axis diameters assume that measured areas were of circles. The "percent vesicularity" numbers are integrated 2-dimensional areas of vesicles. A. Matrix of the explosion breccia (mousse) excluding lithic and glass clasts. Sample 126-791 B-63R-1, Piece 8. B. Lithic clast from the explosion breccia. Sample 791B-70R-1, Piece 12. C. Glass clast within the explosion breccia, similar to clast in Figure 14. Sample 126-791B-63R-1, Piece 8. D. Lava overlying the explosion breccia. Sample 126-791B-47R-1, Piece 11. Note the narrow size distribution and smaller size of vesicles in the matrix vs. the similarity in size distribution between the lava, lithic clast, and even overall glass clast. 


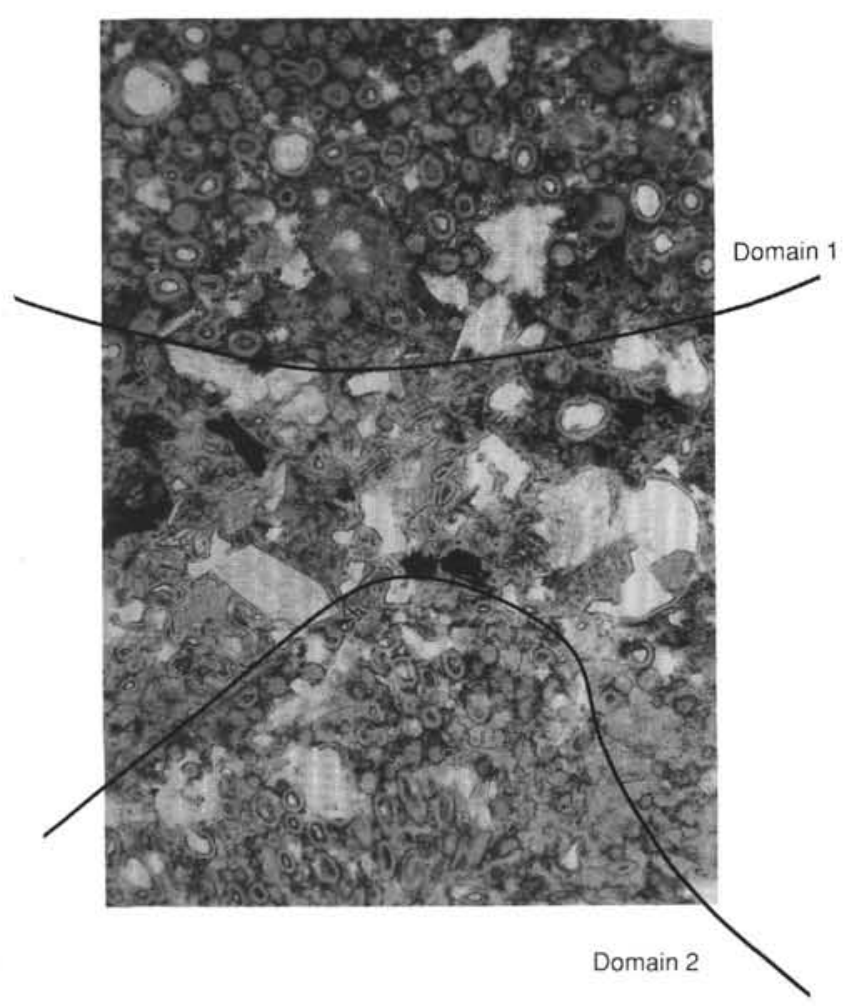

Figure 16. Photomicrograph of mousse matrix showing an annealed contact between scoriaceous domains, one more plastically deformed than the other. Sample 126-791B-67R-1, Piece 5, for which a chemical analysis is given in Table 7.

Appendix 1. XRF analytical background.

\begin{tabular}{|c|c|c|c|}
\hline & Precision ${ }^{a}$ & Accuracy $^{b}$ & $\begin{array}{l}\text { Calibration } \\
\text { range }\end{array}$ \\
\hline \multicolumn{4}{|c|}{ Major elements (wt\%): } \\
\hline & 0.33 & -0.18 & - \\
\hline $\mathrm{TiO}_{2}$ & 0.02 & -0.13 & - \\
\hline $\mathrm{Al}_{2} \mathrm{O}_{3}$ & 0.11 & -0.16 & - \\
\hline $\mathrm{Fe}_{2} \mathrm{O}_{3}$ & 0.08 & -0.06 & - \\
\hline $\mathrm{MgO}$ & 0.03 & +0.02 & - \\
\hline $\mathrm{CaO}$ & 0.15 & -0.12 & - \\
\hline $\mathrm{Na}_{2} \mathrm{O}$ & 0.10 & +0.15 & - \\
\hline $\mathrm{K}_{2} \mathrm{O}$ & 0.03 & -0.07 & - \\
\hline $\mathrm{P}_{2} \mathrm{O}_{5}$ & 0.01 & +0.01 & 二 \\
\hline Sum & 0.69 & & - \\
\hline \multicolumn{4}{|c|}{ Trace elements (ppm): } \\
\hline $\mathrm{Rb}$ & 0.5 & & \\
\hline $\mathrm{Sr}$ & $<1 \%$ & $3 \%$ & $<500$ \\
\hline $\mathrm{Ba}$ & $1-4$ & $2-10$ & $<200$ \\
\hline & $1-3$ & $2-5$ & $<130$ \\
\hline $\mathrm{Nb}$ & 1 & $<1$ & $<15$ \\
\hline $\mathrm{La}$ & $1-2$ & $<2$ & $<50$ \\
\hline $\mathrm{Y}$ & $<1$ & $<1$ & $<50$ \\
\hline $\mathrm{Ni}$ & $<1$ & $1-3$ & $2-170$ \\
\hline $\mathrm{Sc}$ & $<1$ & 2 & $1-40$ \\
\hline
\end{tabular}

"Replication of BCR1 daily during 2 months, as wt \%. Trace element entries are a summary of replications of several standards.

${ }^{b}$ Major elements are differences from Govindaraju (1990) for JB-2; + means UCSC was higher on an anhydrous basis.

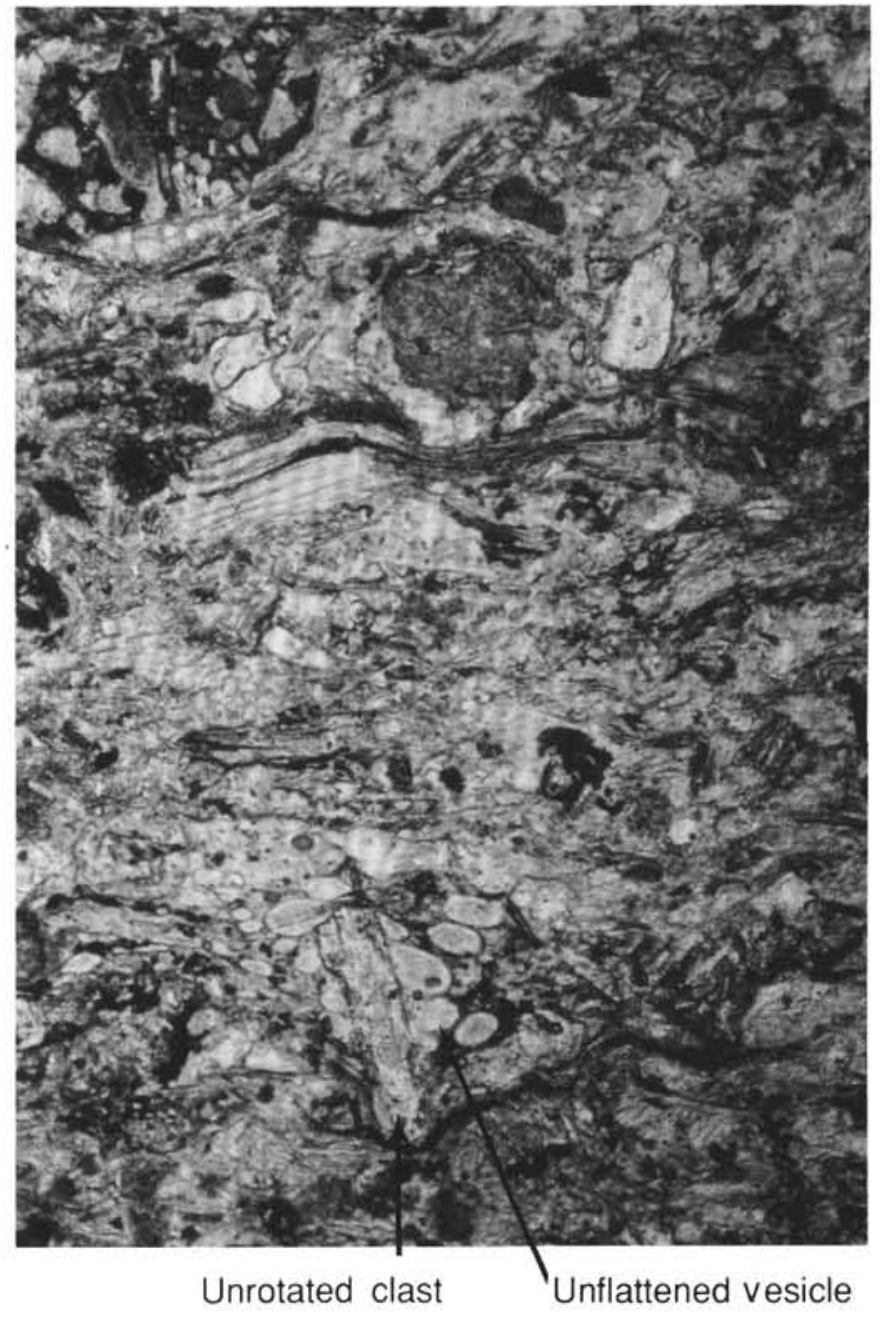

Figure 17. Photomicrograph of the crystal-lithic tuff in the oldest samples at the bottom of Site 791. Sample 126-791B-77R-2, Piece 6a, Unit 20; $\times 95$ magnification. Notice that vesicles are less flattened than pumice fragments, and that the clast in the bottom of the picture lies at a high angle to the others. Both suggest diagenetic alteration during burial or local heating rather than pyroclastic flow. 